Claremont Colleges

Scholarship@ Claremont

KGI Theses and Dissertations

KGI Student Scholarship

$1-1-2012$

\title{
Rapid, Large-Scale Production of Full-Length, Human-Like Monoclonal Antibodies
}

Christopher M. Warner

Keck Graduate Institute

\section{Recommended Citation}

Warner, Christopher M., "Rapid, Large-Scale Production of Full-Length, Human-Like Monoclonal Antibodies" (2012). KGI Theses and Dissertations. Paper 1.

http://scholarship.claremont.edu/kgi_theses/1

DOI: $10.5642 / \mathrm{kgitd} / 1$

This Restricted to Claremont Colleges Dissertation is brought to you for free and open access by the KGI Student Scholarship at Scholarship @ Claremont. It has been accepted for inclusion in KGI Theses and Dissertations by an authorized administrator of Scholarship @ Claremont. For more information, please contact scholarship@cuc.claremont.edu. 


\title{
Rapid, Large-Scale Production of Full-Length, Human-Like Monoclonal Antibodies
}

\author{
$B Y$
}

Christopher Michael Warner 


\section{Copyright by Christopher M. Warner 2012 All rights Reserved}

We, the undersigned, certify that we have read this dissertation of Christopher M. Warner and approve it as adequate in scope and quality for the degree of Doctor of Philosophy.

Dissertation Committee:

Dr. Matthew S. Croughan

Professor, Chair

Dr.Tina Etcheverry

Member

Dr. Edward J. Perkins

Member

Dr.Ali Nadim

Member

Dr. Animesh Ray

PhD Program Director 


\title{
Rapid, Large-Scale Production of Full-Length, Human-Like Monoclonal Antibodies
}

\author{
$B Y$
}

\author{
Christopher Michael Warner
}

A Dissertation submitted to the Faculty of Keck Graduate Institute of Applied Life Sciences in partial fulfillment of the requirements for the degree of Doctor of Philosophy in Applied Life Sciences

Claremont, California

2012

Approved by:

Matthew Croughan Ph.D

George B. and Joy Rathmann Professor, Director of the Amgen Bioprocessing, Keck Graduate Institute, Doctoral Thesis Advisor 


\title{
Abstract \\ Rapid, Large-Scale Production of Full-Length, Human-Like Monoclonal Antibodies
}

\author{
By
}

\section{Christopher M Warner \\ Keck Graduate Institute of Applied Life Sciences 2012}

Current recombinant protein production systems require several months to develop. Existing systems fail to provide timely, flexible, and cost-effective therapies to protect against emergency mass-casualty infections or poisonings. As the identity of many new biological threat agents are unlikely to be known in advance, pre-emptive manufacturing and stockpiling of countermeasures cannot be performed. Preparedness for a biological catastrophe requires a radical solution to replace the current slow scale-up and manufacture of lifesaving medical countermeasures. Subunit vaccines and antibody fragments may be produced in bacteria, yeast, plant or insect cells. However, generation of full-length, human like glycosylated antibodies requires mammalian cell culture due to the cell's ability to carry out complex assembly and processing. Although commercial cell culture methods for antibody production from stable gene expression have been substantially improved over the last 30 years, the time required to achieve full scale production for a new product is too long for a rapid, emergency 
response. An alternative method for rapid production of high quality antibody protein is transient gene expression.

Transient gene expression is an established, routine approach to small scale, researchgrade material of recombinant proteins. It is frequently used to generate gram quantities of material within weeks of lead target identification. In the past, transient gene expression has been considered for emergency production of large production of antibodies, but dismissed due to low titers, high DNA requirements, uncertain regulations, unavailable manufacturing capacity, and uncertain scale-up performance. If these barriers can be overcome in the next few years, emergency use of transient gene expression for production of life saving medical countermeasures would be a viable means to help protect our nation from biological attacks.

The goal of this thesis is to investigate both the technical and operational feasibility of scaling up transient gene expression. In order to investigate the technical feasibility of such a method, a phenomenological understanding of transfection was developed for process characterization, process optimization and scale-up studies. Experiments in shaker flasks and lab-scale bioreactors interrogated a number of factors involved in the transfection process and identified an optimal design space for performing transfections (Chapters 2 and 3). Important factors that were identified include cell/DNA/PEI ratio, transfection incubation time, and agitation set points. Through this optimization process, the highest reported titer (>300 $\mathrm{mg} / \mathrm{L}$ ) in transient $\mathrm{CHO}$ production was achieved.

Experimental transfections also provided calibration metrics for phenomenological models of mass transfer in very large bioreactors. These models were used to investigate the potential of mass transfer limitations upon scale-up (Chapter 2). The results indicate that, with 
appropriate design of the agitation systems, including consideration of the impact of mass transfer of PEI/DNA complexes from the medium to the cells during the transfection stage, scale-up should be successful. In the final stage of experimentation, successful identification of scalable systems for aseptic liquid-cell separation eliminated other potential bottlenecks that may be encountered during scale-up (Chapter 3). A novel combination of existing technology generated simplified transfection protocols, which may be commercialized for alternative markets.

Operational feasibility was investigated through a survey of current manufacturing capacity for mammalian cell culture and their capabilities to provide meaningful emergency production of antibody countermeasures. Process simulation was conducted to analyze process flow, plant design, and cost for large scale production of both plasmid DNA (Chapter 5), a sub-component of transient gene expression, as well as antibody protein (Chapter 4). Simulations predicted that a 1,000-L fermentor would produce sufficient plasmid DNA at a cost of approximately $\$ 377 /$ gram. This DNA could be utilized in a $200,000-L$ facility to produce between 32 and $1,274 \mathrm{~kg}$ of recombinant antibody. Experimentally validated transfection processes were then used to refine simulations. Subsequent simulation resulted in production of $197 \mathrm{~kg}$ within 3 months at a cost of $705 \$ /$ gram mAb. These simulations predict that largescale transient gene expression can provide sufficient lifesaving countermeasures if titer improvements are possible and can be successfully scaled to large bioreactors.

This thesis demonstrates both the operational and technical feasibility of a successful large-scale transient gene expression platform for the production of full-length, human-like 
glycosylated antibodies as medical countermeasures for biological catastrophe. This approach is one critical component of our Nation's arsenal of bio-defense capabilities. 
Dedication

This work is dedicated to my parents and brothers for their unyielding love 


\section{ACKNOWLEDGMENTS}

I would first like to acknowledge the Amgen Foundation for providing the support that made the Amgen Bioprocessing Center, and my research, possible. I would also like to thank the Science Mathematics And Research for Transformation (SMART) scholarship program and everyone at the Naval Postgraduate School for their support.

I would like to thank my advisor and Director of the Amgen bioprocessing Center,

George B. and Joy Rathmann Professor Matthew S. Croughan, for all his direction and guidance. I also wish to thank my thesis committee, Dr. Tina Etchevvery, Professor Ali Nadim, Dr. Edward Perkins and Professor Animesh Ray; they all contributed to the success of this work through challenging discussions and valuable input.

A special thank you to my friends and colleagues at KGI: KiriLynn Svay, Dr. Nathaniel Freund, Delyan Rusev, Dr. Chris Shen, Professor Daniel Byrd, Professor Angelika Niemz, Kristina Roskos, Lindsay Janssen, Tanya Ferguson, Jamie Liu and the many MBS students I have come to know and admire. I would also like to thank all those who have provided invaluable support throughout my education, including: The Chain, Tim Engleman, Ralitsa Kiskinova, Professor Tathagata Dasgupta, and Professor Jenny Darroch. 


\section{TABLE OF CONTENTS}

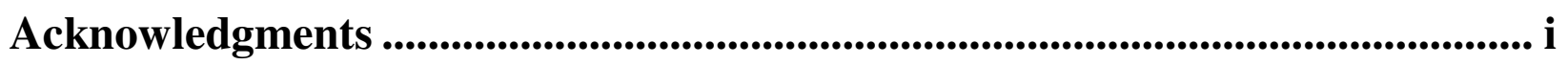

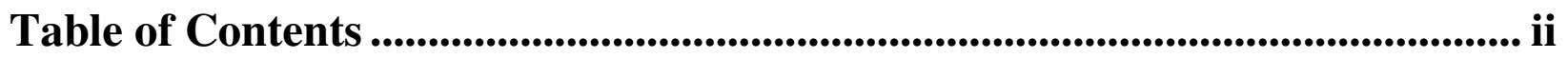

List of Abbreviations ....................................................................................... vi

Table of Figures.................................................................................................. vii

List of Tables ......................................................................................................... viii

Chapter 1. Accelerated manufacturing of large-scale, full-length, human-like glycosylated antibodies for bio-defense..........................................................1

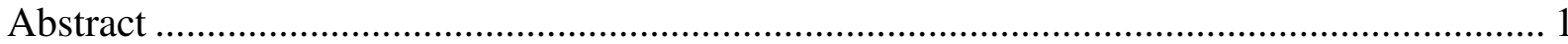

1.1 Recombinant protein production systems needed for catastrophic biological events........... 2

1.2 Capacity within the biopharmaceutical industry …………................................................ 7

1.3 Antibodies require complex assembly .......................................................................... 9

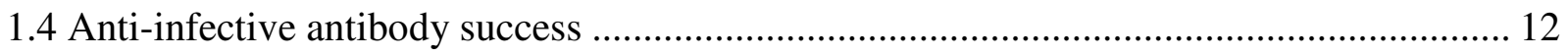

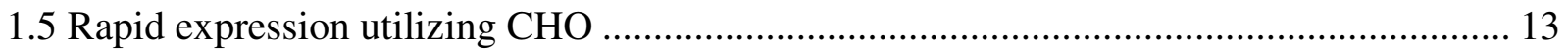

1.6 Current state of transient gene expression....................................................................... 16

1.7 Recent advances in TGE protocols ........................................................................... 19

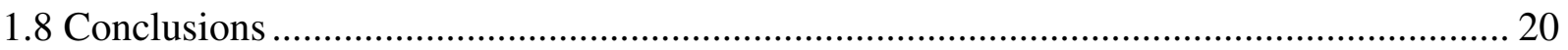

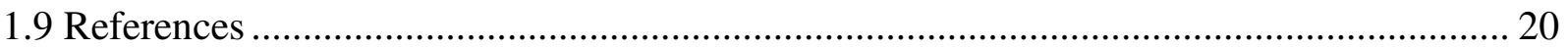

Chapter 2. Engineering considerations for large scale transient gene expression of monoclonal antibodies in $\mathrm{CHO}$ cell culture ...................................27

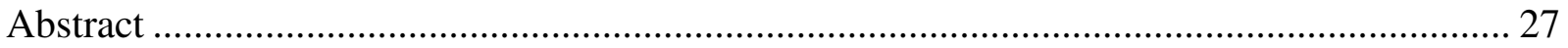

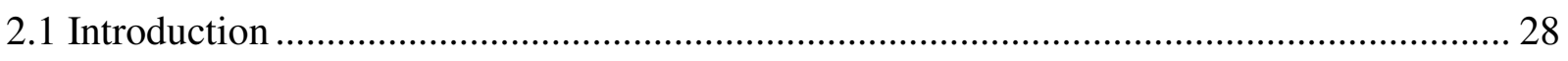

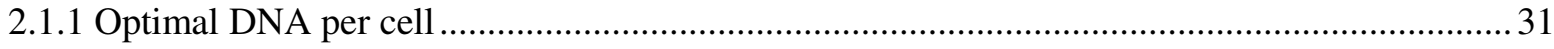

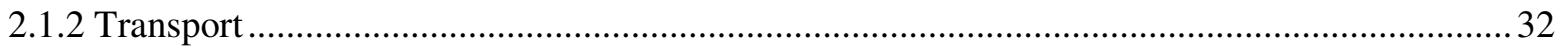

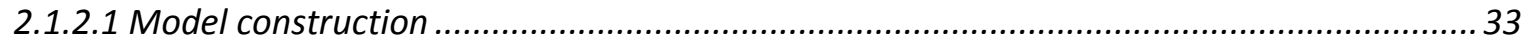

2.1.2.2 Calculate polyplex size effect on mass transport .......................................................... 35

2.1.2.3 Calculate cell density effect on mass transport ............................................................. 36

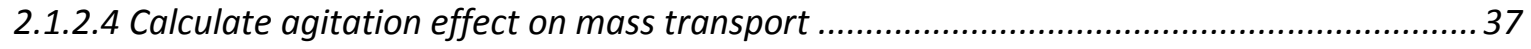

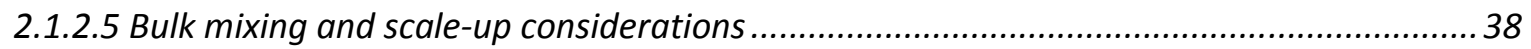


2.2 Materials and methods .................................................................................... 39

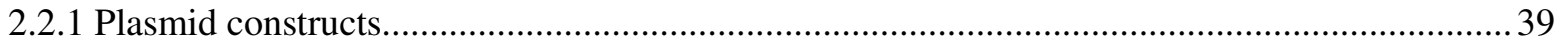

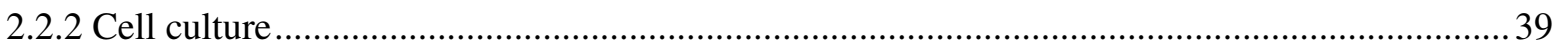

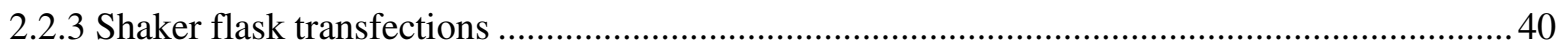

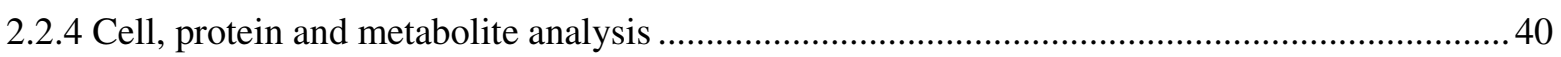

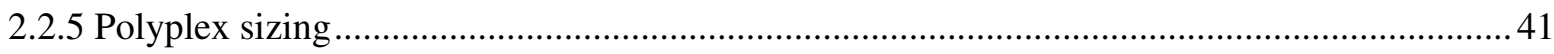

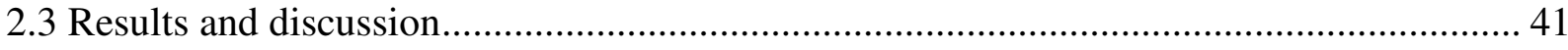

2.3.1 Particle size of DNA/PEI complexes in room temperature agitated media ............................ 41

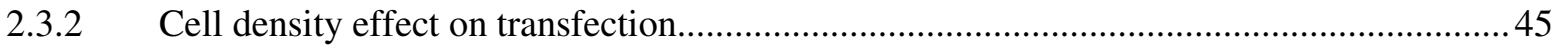

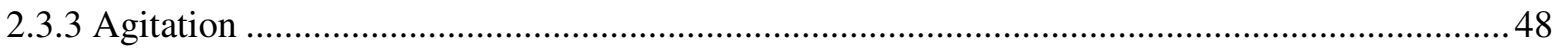

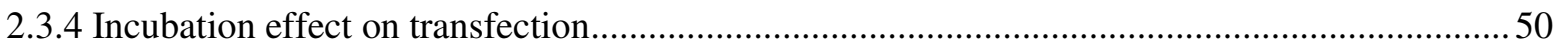

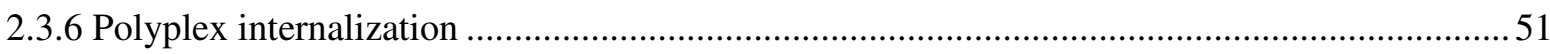

2.3.7 Intracellular polyplex transport and cellular metabolism...................................................51

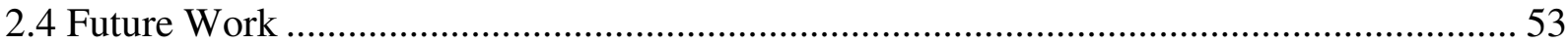

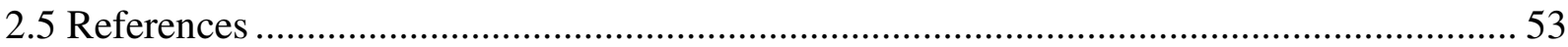

\section{Chapter 3. Optimal Transient Gene Expression systems for Large-Scale} Production of Antibodies.......................................................................................62

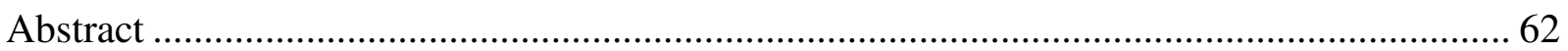

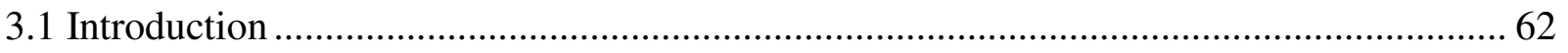

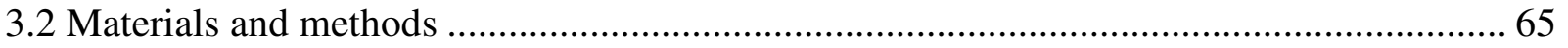

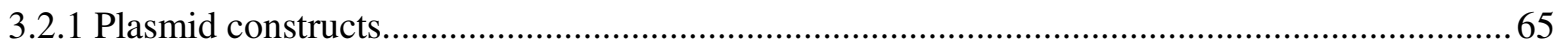

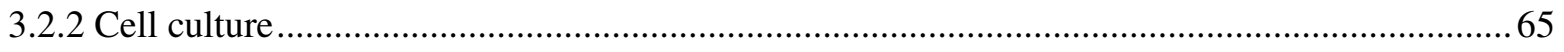

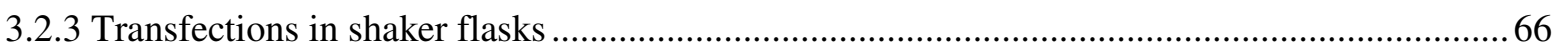

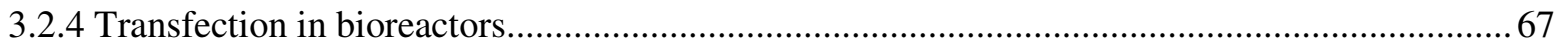

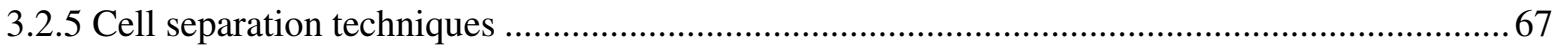

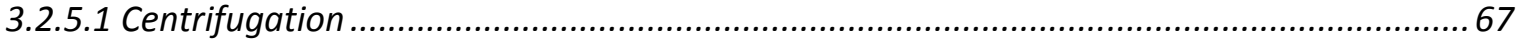

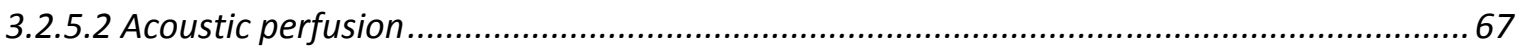

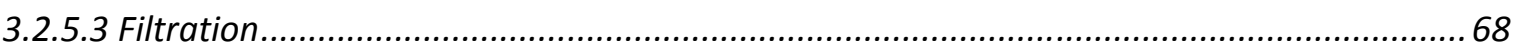

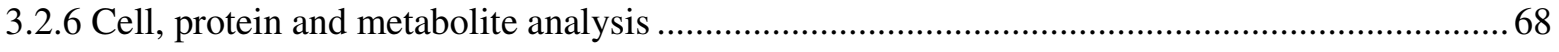

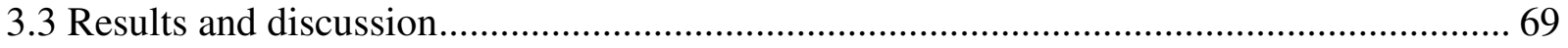

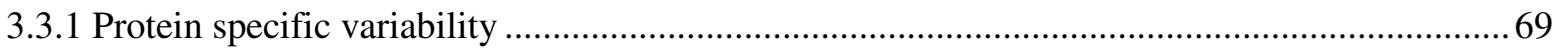

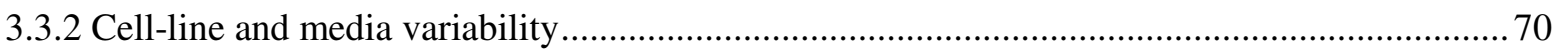




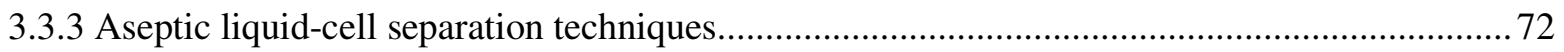

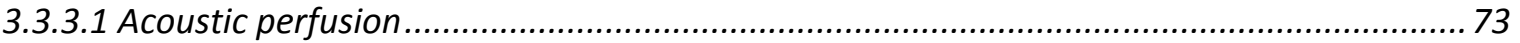

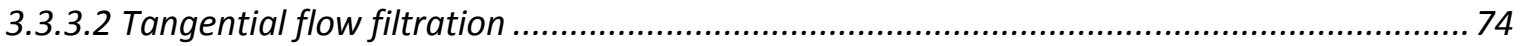

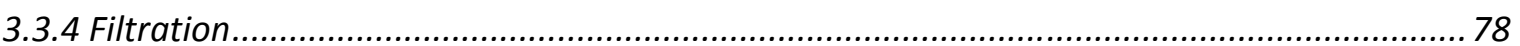

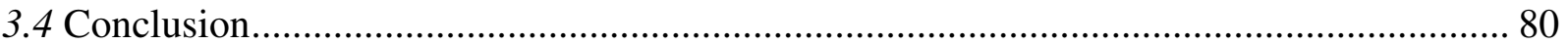

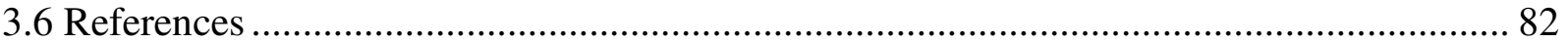

\section{Chapter 4. Processes Simulation for Large-Scale Transient Gene Expression}

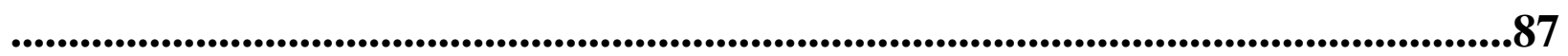

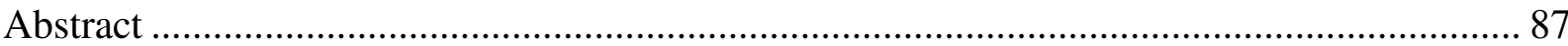

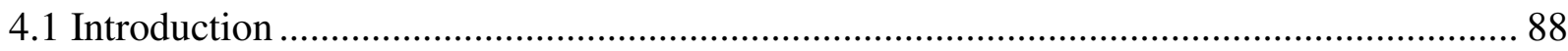

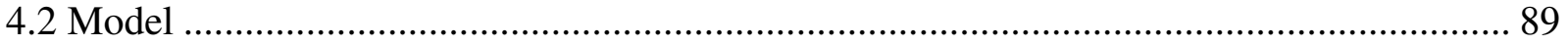

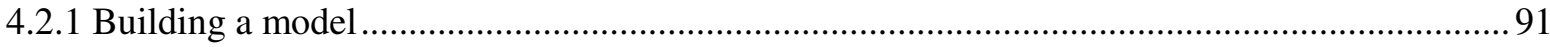

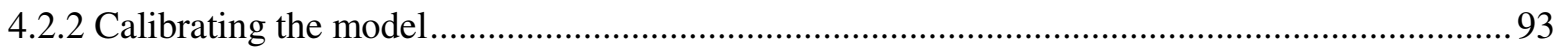

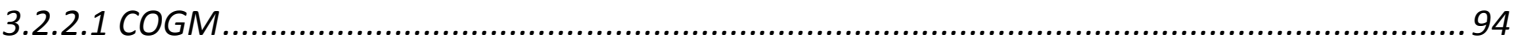

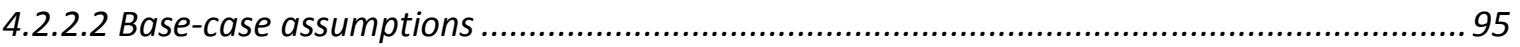

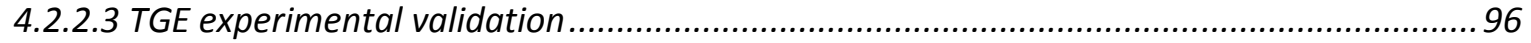

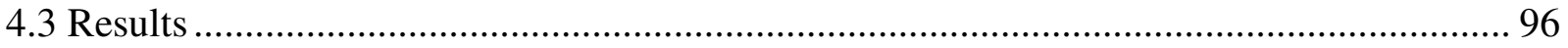

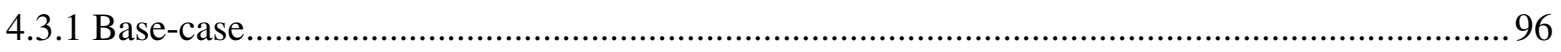

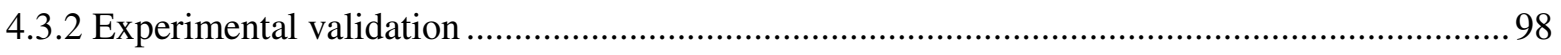

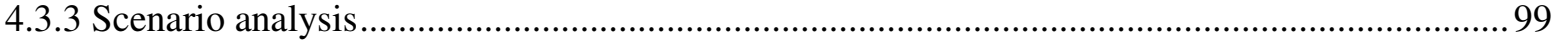

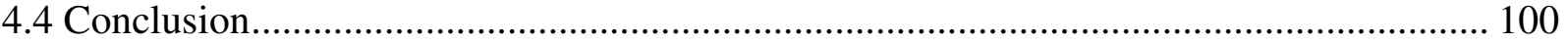

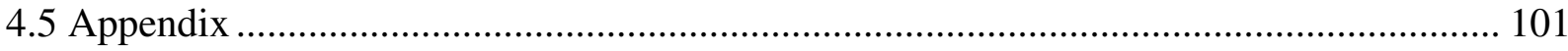

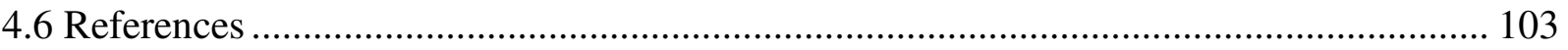

\section{Chapter 5. Plasmid DNA Production for Large Scale Transient Gene} Expression ................................................................................................................................108

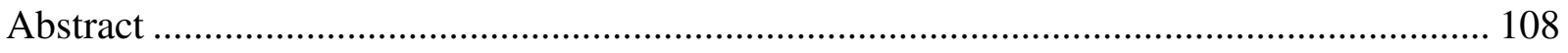

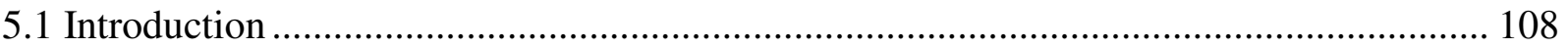

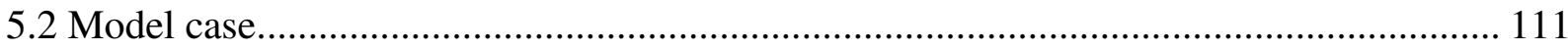

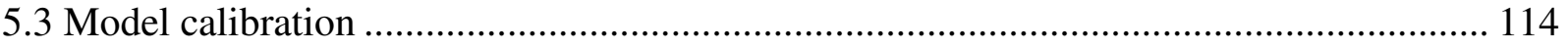

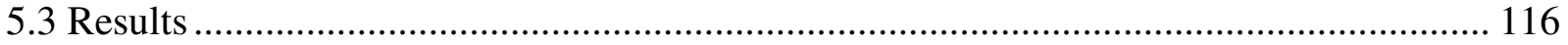

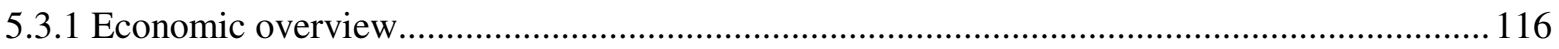




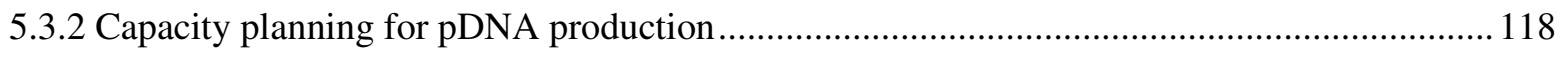

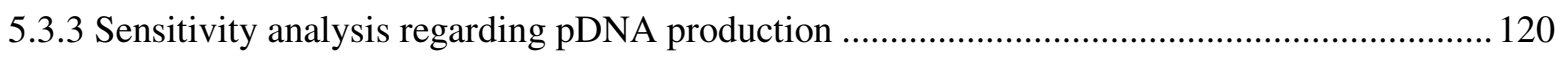

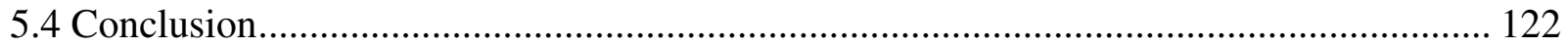

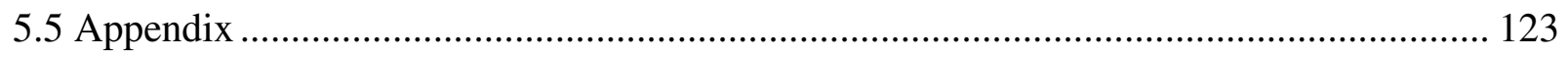

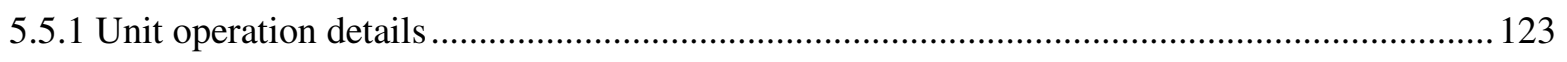

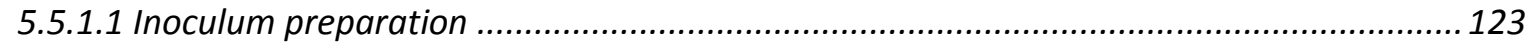

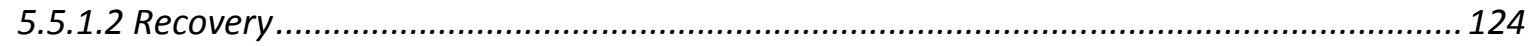

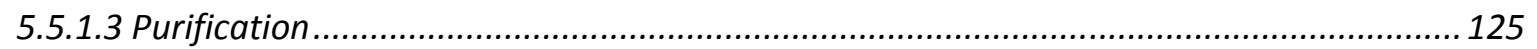

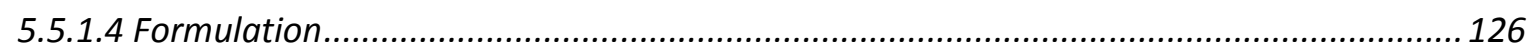

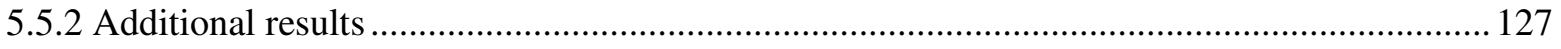

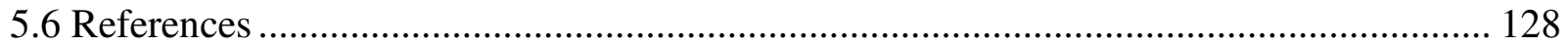

Conclusion and Future Work ...............................................................................139 


\section{LIST OF ABBREVIATIONS}

AIEC- Anion Exchange Chromatography

AMP- Accelerated Manufacture of Pharmaceuticals

BL1/BL2- Baseline process 1/ Baseline process 2

BP- Base pair

CDP-Cell/DNA/PEI ratio

$\mathrm{CHO}$ - Chinese Hamster Ovary

COGM- Cost of Goods Manufactured

COGS- Cost of Goods Sold

DARPA- Defense Advanced Research Projects Agency

DBC- Dynamic Binding Capacity

DCW- Dry Cell Weight

DLS- Dynamic Light Scattering

DOD- Department of Defense

DNA- Deoxyribo Nucleic Acid

EDTA- Ethylenediaminetetraacetic acid

FcyR- Heavy Chain Conserved Receptor

GAGs- Glycosaminoglycans

gDNA- Genomic DNA

HAMA- Human Anti-Mouse Antibodies

HEK- Human Embryonic Kidney

HIC- Hydrophobic Interaction Chromatography

IgG- Immuno Gamma Globulin

IVCD- Integral Viable Cell Density

kDa- Kilo Dalton

$\mathrm{mAB}(\mathrm{s})$ - Monoclonal Antibody

MCB- Master Cell Bank

MWCO- Molecular Weight Cut Off

pDNA- Plasmid DNA

PEI- Polyethylenimine

OD- Optical Density

r-protein(s)- Recombinant Protein

SE- Separation Efficiency

SEC- Size Exclusion Chromatography

SGE - Stable Gene Expression

SUT- Single Use Technology

TE- Tris-EDTA buffer

TGE- Transient Gene Expression

UF/DF- Ultrafiltration/ Diafiltration

VCD- Viable Cell Density

VH- Heavy Chain Variable Region

VL- Light Chain Variable Region 


\section{TABLE OF FIGURES}

Figure 1.1. Biologics demand in 2009. 5

Figure 1.2. Simplified, simulation model to achieve bio-defense production targets within a 12 week period. 6

Figure 1.3. Biomanufacuting capacity in North America, 2002 projected to 2015 .

Figure 1.4. Global capacity utilization for mammalian cell culture.

Figure 1.5. Antibody molecule with glycosylation profile. ___ 10

Figure 1.6. Process flow diagram of $\mathrm{CHO}$ cell culture manufacturing operations.

Figure 2.1. Overview of the transfection process.

Figure 2.2. Dose-dependent cytotoxicity and specific productivity of PEI mediated TGE.__ 32

Figure 2.3. Calculated tansport of polyplexes versus size. ___ 36

Figure 2.4. Calculated cell density effect on transfection. ___ 37

Figure 2.5. Calculated effect of agitation on polyplex mass transfer.__ 38

Figure 2.6. Particle size versus time.

Figure 2.7. Cell density effect on transfection. ___ 47

Figure 2.8. Agitation effect on transfection. ___ 49

Figure 2.9. Normalized time and temperature effect on transfection.__ 50

Figure 3.1. Protein specific variability on TGE. 69

Figure 3.2. Cell and media effects on TGE performance.

Figure 3.3. Acoustic filtration performance. ___ 73

Figure 3.4. Assessment of damage resulting from TFF operations.

Figure 3.5. Conditioned media effect on transfections.

Figure 3.6. Transfection of cells using scalable unit operations.

Figure 3.7. Fish bone diagram of the variables involved in TGE.

Figure 3.8. Comparison of reported CHO-TGE culture titers.

Figure 4.1. Process flow diagram for mAb production with SGE and TGE

Figure 4.2. Base-case flow sheet of large scale, TGE process. ___ 92

Figure 4.3. Simulation results from base-case model.

Figure 4.4. COGM break down for $304 \mathrm{mg} / \mathrm{L}$ process.

Figure 4.5. COGM under different capital cost structures and utilization scenarios.___ 99

Figure 5.1. General plasmid DNA production process. ___ 110

Figure 5.2. Plasmid production and purification flow sheet.____ 113

Figure 5.3. Cost break down per gram of pDNA. ___ 118

Figure 5.4. General process diagram for TGE. ___ 119

Figure 5.5. Project timeline for multiple pDNA production batches. ___ 120

Figure 5.6. Sensitivity analysis on pDNA production processes. ___ 121 


\section{LIST OF TABLES}

Table 1.1. Milestones for bio-defense markets 4

Table 1.2. Transient versus stable gene expression in mammalian cells 16

Table 1.3. Antibody products produced with PEI-mediated TGE processes in mammalian cells __ 20

Table 2.1 Large-scale CHO cell culture in stirred tanks __ 29

Table 2.2. Time scales for various transfection operations ___ 39

Table 2.3. Cell density effect on transfection___ 48

Table 3.1. Protein specific TGE variability ___ 70

Table 3.2. Transfection of cells using scalable unit operations ___ 80

Table 4.1. Capital investment costs for cell culture facilities producing antibodies ___ 93

Table 4.2. Base-case assumptions ___ 96

Table 4.3. Antibody production targets for bio-defense ___ 98

Table 5.1. Fermentation overview ___ 114

Table 5.2. Downstream key assumptions____ 115

Table 5.3. Base-case assumptions ___ 116

Table 5.4. Economic results overview __ 117

Table a5.1. Equipment overview __ 127

Table a5.2. Consumable overview __ 127 


\title{
CHAPTER 1. ACCELERATED MANUFACTURING OF LARGE- SCALE, FULL-LENGTH, HUMAN-LIKE GLYCOSYLATED ANTIBODIES FOR BIO-DEFENSE
}

\begin{abstract}
From the point of DNA sequence confirmation until production of meaningful clinical quantities of novel therapeutics, current manufacturing systems for many glycosylated proteins, such as monoclonal antibodies, require at least several months and often more than a year. Consequently, in the event of mass-casualty epidemics from new infectious agents, or poisonings from new toxins, current systems will fail to provide sufficient and timely quantities of certain emergency medical countermeasures. As the identity of many new biological threats are unlikely to be known in advance, pre-emptive manufacturing and stockpiling of countermeasures cannot always be performed. Preparedness for all biological catastrophes requires a radical solution to replace the current slow scale-up and manufacture of certain lifesaving medical countermeasures.
\end{abstract}

As medical countermeasures, antibodies have the potential advantage of providing immediate protection, but the disadvantage of requiring moderate to high dosing levels per person. While subunit vaccines and antibody fragments may be produced in bacteria, yeast, plant or insect cells, the majority of full-length antibody manufacturing processes utilize mammalian cells. This is due to their ability to carry out complex assembly and processing, including human-like glycosylation, and thus secrete fully active antibodies in the culture fluid, often at concentrations of $1 \mathrm{~g} / \mathrm{L}$ or higher. Subsequent recovery and purification is readily performed using industry standard approaches with high overall yields (70 - 80\%). Current 
clinical and commercial manufacturing methods use stable cell lines for protein expression, wherein the gene coding for the protein of interest is stably integrated into the host cell genome. The generation, identification, banking, testing, and scale-up of suitable stable clones generally takes many months. Because this development time is not compatible with emergency manufacturing, an alternative method for rapid production of medical counter measure antibodies is needed. One such potential technique is transient gene expression.

Transient gene expression is a common approach for production of research-grade antibodies. It is frequently used to generate milligram to gram quantities of material within two to three weeks of DNA sequence confirmation. In the past, transient systems have been considered for emergency production of large quantities of antibodies, but dismissed due to low titers, high cost of DNA, uncertain regulatory environment, and the lack of sufficient, available manufacturing capacity. Recent developments, however, have substantially enhanced the viability of such an approach. This article will explore these developments and investigate the use of transient gene expression for rapid production of antibody-based medical countermeasures.

\subsection{Recombinant protein production systems needed for catastrophic}

\section{biological events}

Despite advancements in the use of early detection systems, integrated epidemiologic surveillance, vaccination, and use of antimicrobial and antiviral agents, the final line of defense against a biological pathogen is the immune system of the exposed individual. Anti-microbial and anti-viral therapies may not work on all biological agents, especially resistant strains and 
toxin-based pathogens. Similarly, vaccination requires a window before protective responses are effective, often including multiple injections. Passive administration of immunotherapeutics, especially monoclonal antibodies (mAbs), can provide a state of immediate immunity that can last for weeks and possibly months. ${ }^{1,2}$

The market demand for bio-defense has been defined, at least in one aspect, by the Defense Advanced Research Projects Agency (DARPA) through their Accelerated Manufacture of Pharmaceuticals (AMP) program. ${ }^{3}$ As a starting point, these guidelines represent DARPA's estimate of the production requirements for emergency medical countermeasures sufficient to protect US military personnel ( $\sim 3$ million people). Compared to a civilian population, this quantity would translate to $1 \%$ of the total US population ( 300 million), and would only be sufficient for initial clusters of disease outbreak, early responders, and military and police forces. Thus, this 3 million dose estimate defines a low end of the market demand for biodefense medical countermeasures, and provides metrics against which one can assess alternative capabilities.

The AMP program is a three phase system intended to build manufacturing capability for both vaccines and antibody recombinant proteins (r-proteins). An interested party could apply for Phase 1 funding, which requires production of either $12 \mathrm{Kg}$ of antibody or $1.2 \mathrm{~g}$ of vaccine within a 90 day period. If successful, the party could apply for Phase 2 funding wherein a 10x expansion of production capabilities would be necessary to generate $120 \mathrm{~kg}$ of antibody or $12 \mathrm{~g}$ of vaccine within a 90 day period. The final phase requires an additional 10x expansion of production capability to generate $1200 \mathrm{~kg}$ of antibody or $120 \mathrm{~g}$ of vaccine within 90 days (Table 1.1). Currently, there are three different partnerships attempting to meet vaccine 
production targets, all based upon subunit vaccines made through bacterial, fungal and plant technologies. ${ }^{4}$ There has not been, however, any significant progress to date toward hitting the much more challenging antibody production targets.

\begin{tabular}{|c|c|c|}
\hline \multicolumn{3}{|c|}{$\begin{array}{l}\text { Table 1.1. Milestones for bio-defense } \\
\text { markets }\end{array}$} \\
\hline Phase & Antibody & Vaccine \\
\hline 1 & $12 \mathrm{Kg}$ & $1.2 \mathrm{~g}$ \\
\hline 2 & $120 \mathrm{Kg}$ & $12 \mathrm{~g}$ \\
\hline 3 & $1200 \mathrm{Kg}$ & $120 \mathrm{~g}$ \\
\hline
\end{tabular}

One of the reasons for the lack of success in rapid production of antibodies is an absence of private sector bio-manufacturing firms. This is, in part, due to difficult requirements in bio-defense markets. The Phase 3 production target of $1,200 \mathrm{Kg}$ of antibody is large compared to other biologic products and revenue streams are not predictable. The worldwide market for biologics in 2009 was $\$ 95$ billion with 130 biologic products, which is $11 \%$ of the total pharmaceutical market and $16 \%$ larger compared to the previous year. ${ }^{5}$ Of these 130 molecules, 27 biopharmaceutical products had sales in excess of $\$ 1$ billion of which 17 were manufactured by mammalian cell culture. Nine of these were antibody-based products, including full length antibodies, antibody fragments, and Fc-fusion proteins. Of the full-length antibodies, only three have production targets larger than those in Phase 3 (Figure 1.1). 


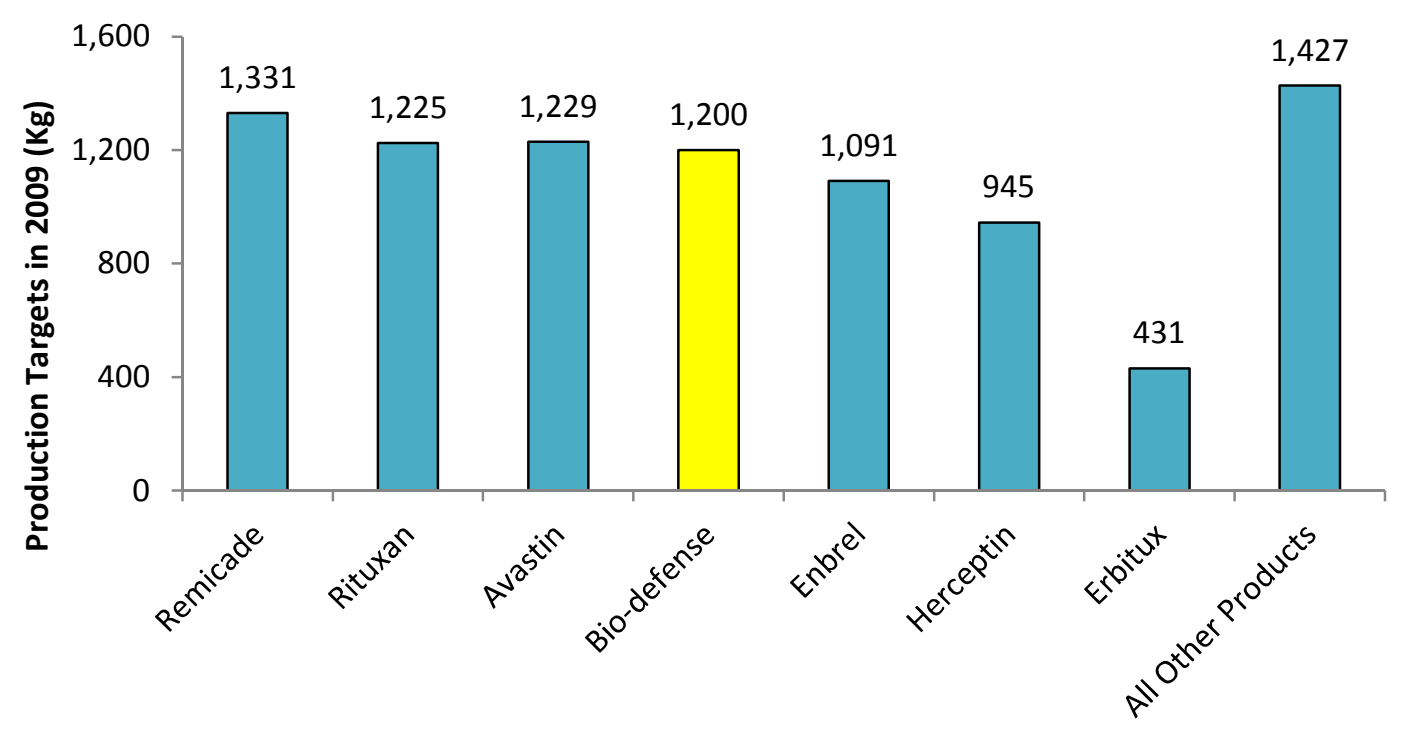

Figure 1.1. Biologics demand in 2009.

Estimated demand in 2009 for the top six monoclonal antibody products mammalian cell culture products. Adapted from Levine 2010. Requirements were forecasted from previously filed annual reports.

In order to estimate the possibility of manufacturing $1,200 \mathrm{Kg}$ of antibody material, a simplified, estimation model was constructed that evaluates manufacturing processes with a range of titers (50- $1500 \mathrm{mg} / \mathrm{L})$ and a range of bioreactor sizes $(500-25,000 \mathrm{~L})$. Antibody production output is shown in Figure 1.2. This estimation model assumes eight dedicated production reactors of any given size, production culture durations of 13 days, with a 1-day turnaround, resulting in a 2-week cycle time, and 70\% downstream yield. This model identified a number of configurations that are able to satisfy Phase 1 and Phase 2 goals for antibody production. For instance, eight $25,000 \mathrm{~L}$ reactors with a final titer of $100 \mathrm{mg} / \mathrm{L}$ would be sufficient to satisfy Phase 2 targets of $120 \mathrm{~kg}$. Similarly, a process with $1000 \mathrm{mg} / \mathrm{L}$ in eight 2,500 L bioreactors, which may consist of disposable bioreactors, would satisfy Phase 2 production targets. Phase 3 targets, however, would require a process with $1000 \mathrm{mg} / \mathrm{L}$ and a plant configuration of eight 25,000 L bioreactors. One such plant configuration, Genentech's 
Vacaville II plant, is currently sitting idle and could provide sufficient capacity for bio-defense production. ${ }^{6}$ Although not quite as large as the Vacaville II plant, there are additional largescale antibody production plants sitting idle elsewhere in the US.
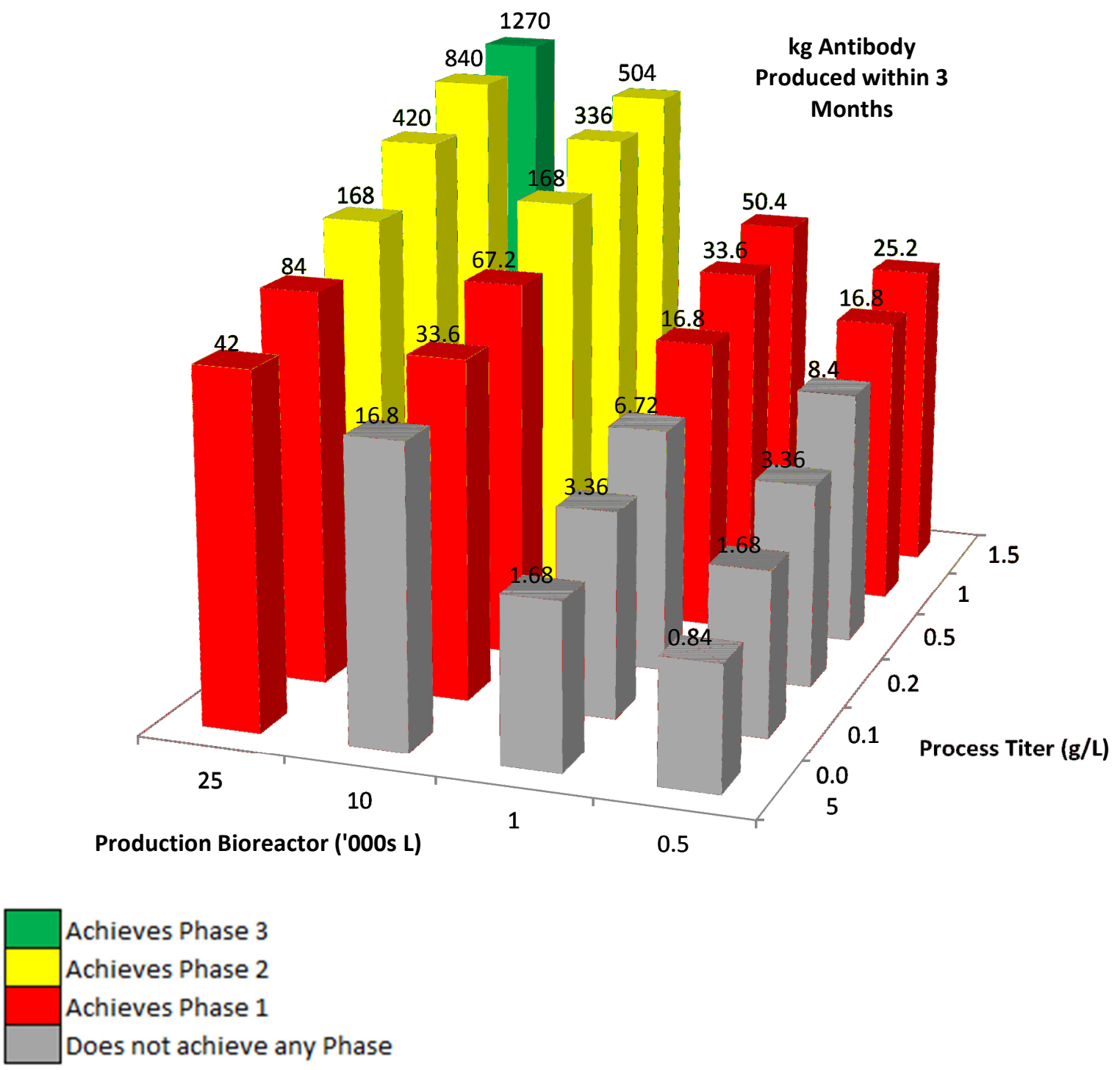

Figure 1.2. Simplified, simulation model to achieve bio-defense production targets within a 12 week period. Production model shows the number kg produced within a three month time frame. Production output is displayed above each condition. This estimation model assumes eight dedicated production reactors of any given size, production culture durations of 13 days, with a 1-day turnaround, resulting in a 2-week cycle time, and $70 \%$ downstream yield. 


\subsection{Capacity within the biopharmaceutical industry}

Employment of large scale bioreactors may be able to meet capacity requirements for bio-defense. Access to this capacity may occur in a number of fashions. One possibility would be through existing installed, stainless-steel bioreactors. The industry's proclivity for these reactors increased available capacity over the last decade, and based upon current project already underway, will lead to further increases in capacity over, at least, the next few years.

(Figure 1.3).

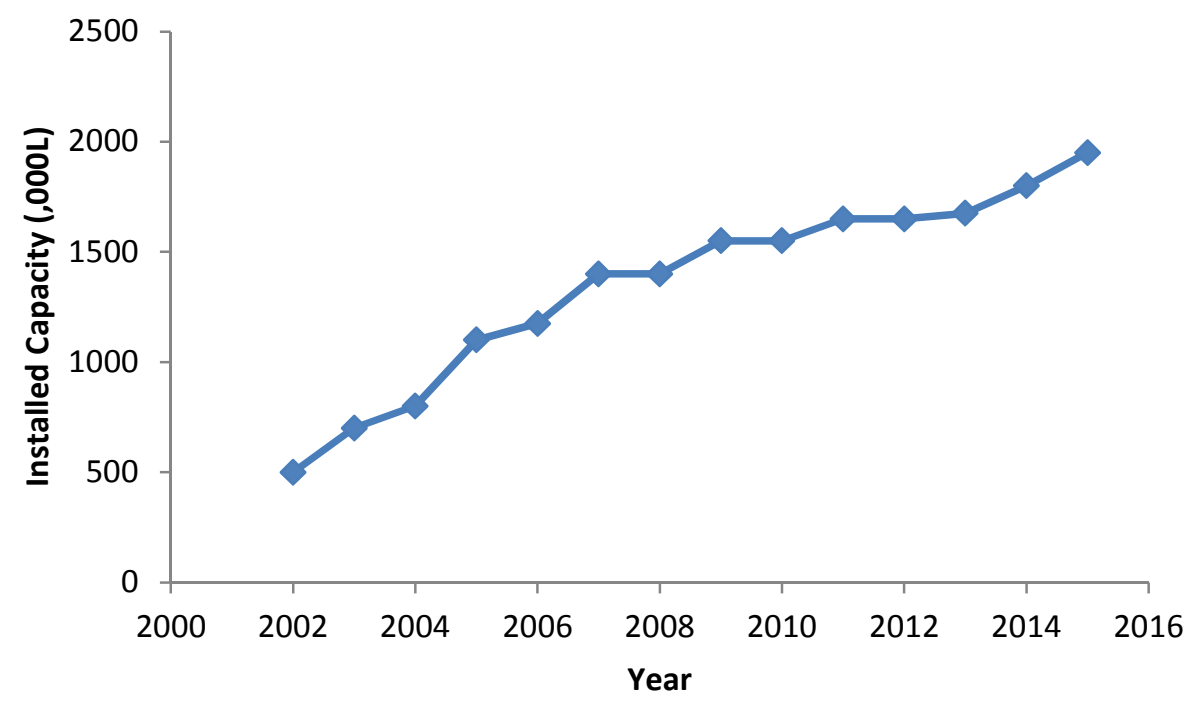

Figure 1.3. Biomanufacuting capacity in North America, 2002 projected to 2015.

Mammalian-based GMP clinical and commercial facilities. Disposable and roller bottles systems were excluded from analysis due to the difficulty assessing and forecasting their volume accurately. Adapted from Levine $2010^{5}$ and Reynolds $2010^{7}$.

Unless a new use is found, such as for medical-counter measure production, large-scale stainless steel bioreactor capacity will likely be underutilized for several years. Levine found 
that only $69 \%$ of installed mammalian cell bioreactor capacity is currently being used (Figure 1.4) $)^{5}$. There are two primary reasons for this moderate bioreactor utilization rate.

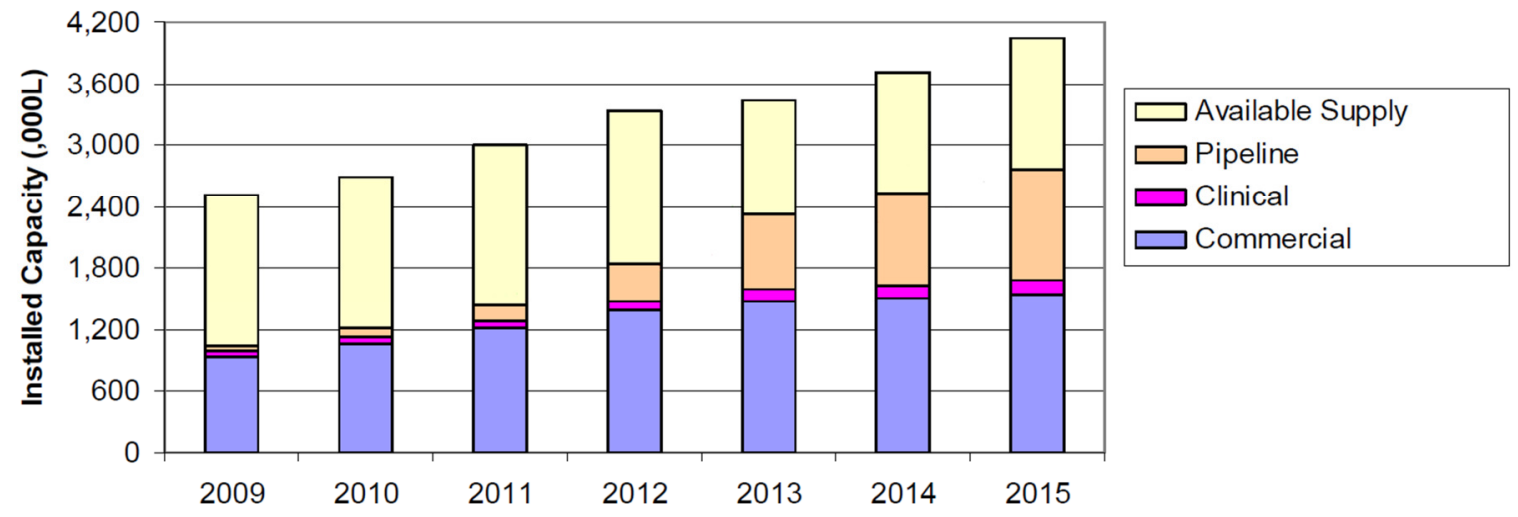

Figure 1.4. Global capacity utilization for mammalian cell culture. Adapted from Levine $2010^{5}$.

First, there have been dramatic advances in cell culture productivity. Commercial cell culture titers have been doubling similar to Moore's law, every 3.4 years. ${ }^{8}$ Commercial cell culture processes for clinical production now have titers in the range of 4-10 g/L. ${ }^{9-11} \mathrm{New}$, higher titer processes for established products are regularly approved and implemented for commercial production, resulting in reduced manufacturing plant time demands for those products.

Second, many firms adopt a risk adverse approach to managing capacity, due to both the skewed high cost of stocking out compared to the cost of carrying idle capacity, as well as the ethical considerations around potentially stocking out of a life-saving drug. Accordingly, many firms target the high end of market estimates, while assuming little or no gain in future titers, when they are sizing and designing manufacturing plants. ${ }^{12,13}$ 
Due to an abundance of installed stainless steel bioreactors, bio-defense production is possible within existing facilities. The $31 \%$ of capacity that is currently not being used within the industry could satisfy the demands of bio-defense under many scenarios.

Another option for bio-defense production is through the use of disposable bioreactors, or what is sometimes termed single-use-teachnology (SUT). Because of an escalation of interest in SUTs, there have been significant advances in both disopable design and cost. ${ }^{14,15}$ Compatible with nearly all aspects of antibody production, including upstream cultivation as well as downstream purification, SUTs are able to provide an end-to-end solution for

biomanufacturing. ${ }^{16-18}$ In addition, SUTs are able to be deployed in a variety of manufacturing locations, including military Forward Operating Bases (FOBs), which may include sterile warehouses, supply depots, or mobile manufacturing facilities. Such installations may result in on-site, on-demand manufacturing capacbilities. With a plethora of possibile capacity configurations, selection of a feasible cell culture process is essential. Selection of such a process includes determining an optimal host and expression system, which will be discussed below.

\subsection{Antibodies require complex assembly}

All human antibodies, or Immuno-Gamma globulins (IgG), contain a glycosylation site at an asparagine residue (N297) in the Fc domain (Figure 1.5). ${ }^{19}$ Other antibody isotypes often contain additional $\mathrm{N}$-linked and $\mathrm{O}$-linked glycans in the $\mathrm{Fc}$ domain and hinge region. In addition, $30 \%$ of human IgG antibodies contain N-linked glycosylation sites within the Fab domains, primarily attached within the variable regions ( $\mathrm{VH}$ and/or $\mathrm{VL}) .{ }^{20,21}$ 
A

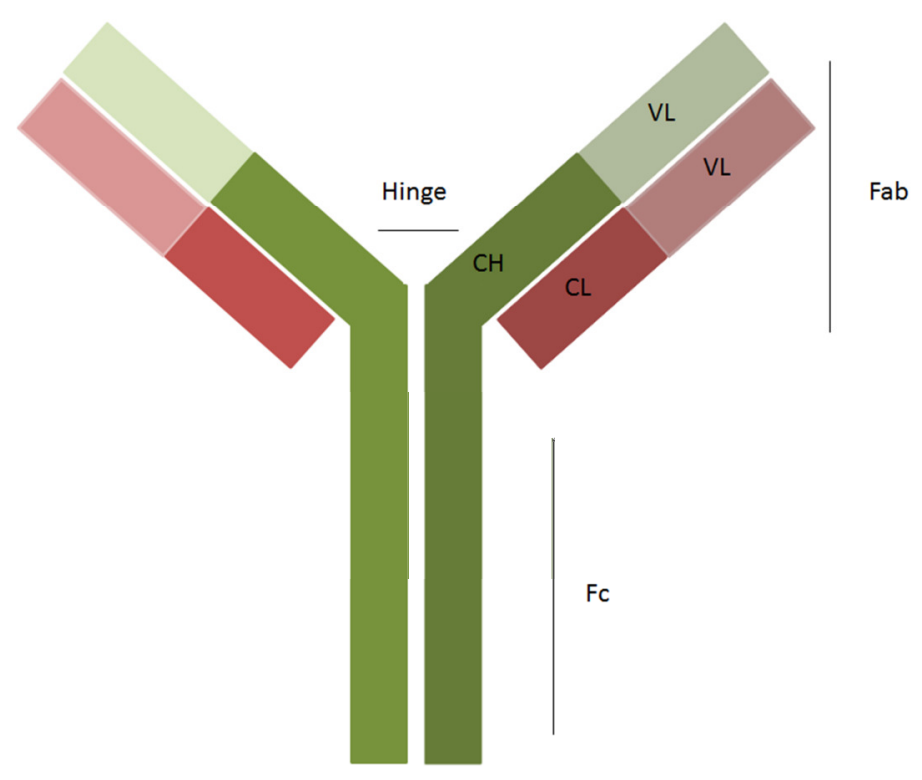

B
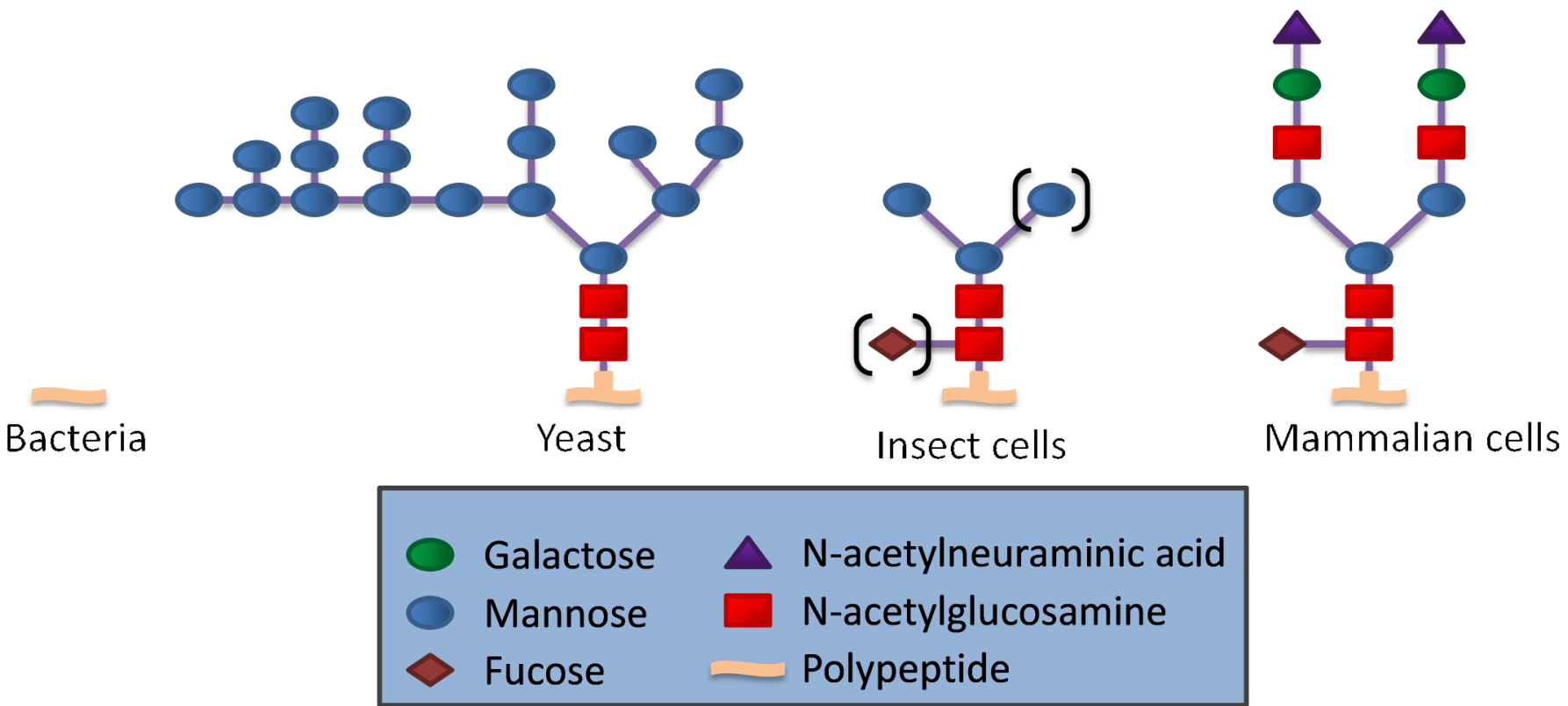

Figure 1.5. Antibody molecule with glycosylation profile.

A) Structure of the $\operatorname{IgG}$ molecule including variable $(\mathrm{V})$ and constant $(\mathrm{C})$ regions as well as heavy $(\mathrm{H})$ and light $(\mathrm{L})$ chain components. Figure adopted from Peterson et al. $2006^{45}$. B Glysocylation patterns between expression systems, adapted from Jena $2012^{46}$. 
There are a number of ways these glycosylation moieties modulate both In vivo potency and In vitro stability of an antibody. The glycan at N297 in the Fc domain can affect protein resistance to proteolysis and the propensity to aggregate In vitro. ${ }^{22,23}$ Early studies with human mouse chimeric IgG1 indicated that altered glycosylation can increase sensitivity to enzymatic digestion. ${ }^{24}$ Moreover, certain glycan patterns confer greater protection to proteolysis than others. $^{25,26}$ Similar to enzymatic digestion, the thermal stability of full-length antibodies decreases when glycosylation is removed. ${ }^{27}$

Glycosylation is also important for therapeutic efficacy. Upon antigen binding, antibodies form an immune complex which mediates the recruitment of complement proteins and triggers immune response signaling through $\mathrm{Fc}$ receptors $(\mathrm{Fc \gamma Rs}) .^{28}$ Antibodies destroy pathogenic cells through antibody-dependent cellular cytotoxicity (ADCC) and antibody dependent cell-mediated phagocytosis (ADCP). These mechanisms rely on the interaction between glycosylation of the antibody and the FcyRs. ${ }^{29-34}$ Often, proper glycosylation is critical for therapeutic outcome.

Glycan heterogeneity in therapeutic antibodies is affected by many factors, including expression system host (i.e. mammalian, plant, yeast, and transgenic animals), the particular cell line (e.g., CHO vs. NSO), culture milieu, and downstream processing. ${ }^{35}$ To date, all FDAapproved therapeutic antibodies have been produced in either $\mathrm{CHO}$ cells or in mouse myeloma cells (NSO or SP2/0). ${ }^{36}$ Mammalian cell expression systems, especially $\mathrm{CHO}$, have been preferred as their protein glycosylation machinery largely resembles those found in humans ${ }^{37,38}$ and they can be cultured to high densities in chemically-defined medium. Along these lines, certain mammalian expression systems such as $\mathrm{CHO}$ are preferred as others may induce undesired 
immunogenicity in humans, or reduce therapeutic efficacy. For example, Cetuximab ${ }^{\text {TM }}$ produced in the murine myeloma cell line $\mathrm{SP} 2 / 0$ is a chimeric mouse-human IgG1 monoclonal antibody that binds the epidermal growth factor receptor (EGFR). $22 \%$ of patients treated with Cetuximab $^{\text {TM }}$ had severe hypersensitivity reactions, characterized by human anti-mouse antibodies (HAMA), that were specific for the mouse produced glycan. ${ }^{39}$

While mammalian systems are the preferred expression system for glycosylated antibodies, $\mathrm{CHO}$ cells are preferred over other mammalian expression systems. There has been significant progress in rapid manufacturing using Human Embryonic Kidney (HEK) cell lines because of a natural episomal system that maintains plasmids more effectively than other cell lines. ${ }^{40,41}$ HEK, however, have been found to produce altered glyscoylation, while $\mathrm{CHO}$ have been shown to reproducibly produce human like glycosylation. ${ }^{42-44}$ Therefore, the use of $\mathrm{CHO}$ cells as the expression system is preferred for the production of full-length, human like glycosylated antibodies for bio-defense.

\subsection{Anti-infective antibody success}

Passive antibody preparations have been generated against a number of biological pathogens. These include many of the Class A, B, and C agents, such as RSV, Vaccinia, Hepatits B and C, Dengue, HIV, Ebloa, Nipah, Incluenza, Bacillus anthracis and its toxin, Yersinia pestis, Clostridium botulinum neurotoxin, and many others. ${ }^{47,48}$ Success of many of these molecules result from three inter-related characteristics. First, the antibody targets biologically relevant epitopes on the pathogen or toxin of interest with high affinity. Second, the antibody has a long

serum half-life. Last, the antibody leads to effective pathogen clearance. ${ }^{49,50}$ Antibody- 
mediated clearance of the antigen is typically associated with accumulation of the antibodyantigen complexes in the liver and/or spleen. ${ }^{51}$ Neutralization of bacterial toxins has been shown to be dependent on maintaining antibody interaction with FcyRs through proper glycosylation. ${ }^{52}$ In fact, one study demonstrated that an antibody preparation imparted significant protection against the botuliunum neurotoxin only when a full-length, humanglycosylated antibody was present. The authors hypothesized that the full- length antibody provided a clearance mechanism where toxin was removed from the system. ${ }^{53}$

\subsection{Rapid expression utilizing CHO}

Commercial cell culture expression systems utilize stable gene expression (SGE) platforms to produce r-protein. SGE processes include identification of the antibody DNA sequence, which is then cloned into a plasmid expression vector and transfected into $\mathrm{CHO}$ cells where the plasmid is stably integrated in the host genome. Cells are subjected to multiple rounds of amplification wherein the gene of interest is amplified and specific productivities are increased up to $25-50 \mathrm{pg} /$ cell-day or higher. Amplified cells are tested for stability and characterized through a battery of tests. Ultimately this strain selection process generates a clonal Master Cell Bank (MCB), which contains cells that will be used exclusively throughout commercial manufacture. Cells within the MCB typically have high rates of protein production, fast doubling times, and reproducible operating characteristics. ${ }^{54-56} \mathrm{MCB}$ generation is, however, a costly and lengthy process (from 4-12 months; Figure 1.6A). Once the MCB is generated, inoculum is created by expanding cell mass through a series of cultures. Expanded inoculum is cultivated in a production bioreactor, where media formulation and culture 
conditions are optimized for r-protein production. R-proteins are subsequently purified through centrifugation, filtration and column chromatography. These purification operations remove host cell proteins, host cell DNA, endogenous retrovirus, and other impurities, creating the drug substance. The process culminates in a final vialing step, often called fill/finish to generate the final product. ${ }^{57,58}$

A

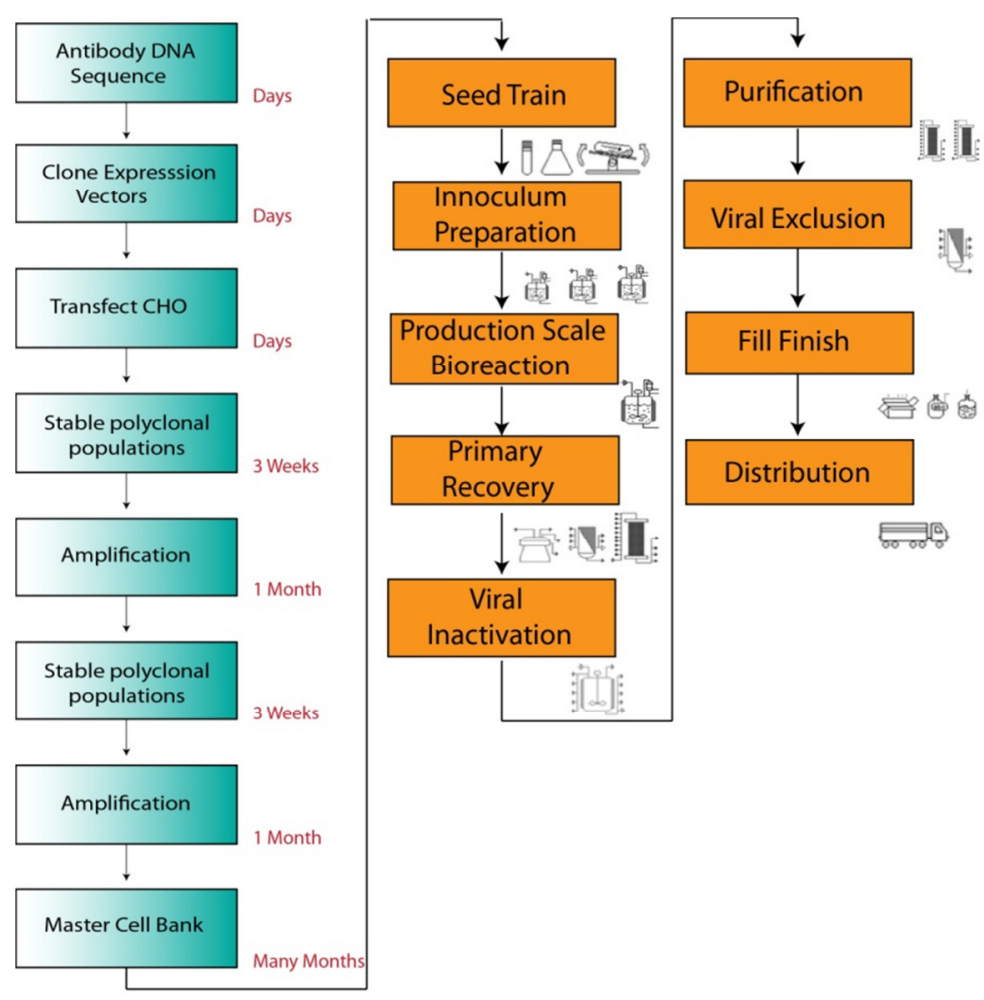




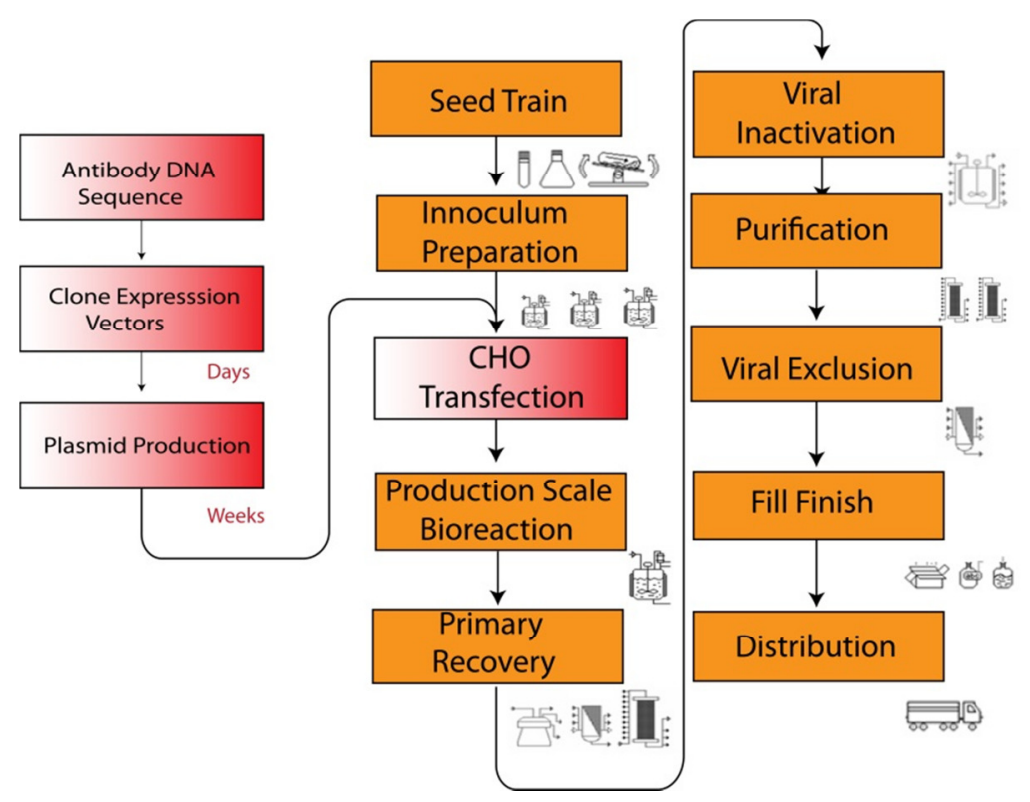

Figure 1.6. Process flow diagram of $\mathrm{CHO}$ cell culture manufacturing operations.

A) Stable gene expression and B) Transient gene expression. Shared operations are shown in orange while unique operations are shaded in either red or green

Transient gene expression (TGE) utilizes the same downstream platform as SGE, but does not require the timely development of a master cell bank (Figure 1.6B). Instead of an MCB, TGE relies on cultivation of an aggregate pool of transfected $\mathrm{CHO}$ cells, in which the gene of interest is maintained extra-chromosomally. As plasmid DNA is not maintained throughout subsequent generations, new pools of transfectants must be created for each batch of production. TGE is, therefore much more rapid than SGE, but suffers from low specific productivities, and thus, overall titer. In addition, the high cost of DNA increases the cost of goods manufactured (COGM) of drug substance. A comparison of the two different systems (Table 1.2) demonstrates the advantages and disadvantages of each system. 


\begin{tabular}{|l|l|}
\hline \multicolumn{2}{|l|}{ Table 1.2. Transient versus stable gene expression in mammalian cells } \\
\hline Transient expression & Stable expression \\
\hline $\begin{array}{l}\text { Expression of transfected genes are usually } \\
\text { within 16-96 h, but expression is not } \\
\text { propagated through subsequent generations }\end{array}$ & $\begin{array}{l}\text { Heterologous DNA is integrated into the host } \\
\text { genome and is stable throughout many } \\
\text { generations }\end{array}$ \\
$\begin{array}{l}\text { Transfection requires a large amount of plasmid } \\
\text { DNA }\end{array}$ & $\begin{array}{l}\text { Cell line development and testing requires an } \\
\text { extensive period (4-12 months) }\end{array}$ \\
$\begin{array}{l}\text { Expression level usually is relatively low } \\
\text { (5-100 mg/L) }\end{array}$ & $\begin{array}{l}\text { After amplification and high producer selection, } \\
\text { expression level is relatively high (1,000-10,000 } \\
\text { mg/L) }\end{array}$ \\
$\begin{array}{l}\text { Expression product is good for pre-clinical } \\
\text { assessment, but no clear guidelines for clinical } \\
\text { production }\end{array}$ & $\begin{array}{l}\text { Stable cells lines can be used for large scale } \\
\text { manufacturing leading to clinical trials and } \\
\text { commercialization }\end{array}$ \\
$\begin{array}{l}\text { It takes only a short period to expression of a } \\
\text { product for "Proof of Principal" demonstration }\end{array}$ & \\
\hline
\end{tabular}

\subsection{Current state of transient gene expression}

While transfection protocols have yet to be standardized, many components in the $r$ protein production process through TGE is similar to those found in SGE; including seed train expansion, harvest, purification, fill and finish. ${ }^{54}$ Transient systems provide the same high quality protein, just much more quickly. ${ }^{40}$ Several methods for gene transfer have been optimized for chemically defined transfection of animal cells, including both viral and non-viral methods.

Viral transient transfection includes the use of adeno-, alpha-, baculo-, lenti-, retro- and vaccina virus particles. Although these vehicles are very effective at delivering intact plasmid DNA into the nucleus, their use is limited due to limited DNA carrying capacity, lengthy processes for recombinant virus isolation, viral stock amplification and titration, bio-safety 
issues, and high cost of production. ${ }^{59}$ Furthermore, viral-based processes are not allowed in any of the current large scale cell cultures plants, such as those built and operated by biopharmaceutical manufacturing firms. This is because it is difficult to validate cleaning, generating significant turnaround time and increases contamination risk for subsequent nonviral based production.

Non-viral methods for transient gene expression can be separated into mechanical and non-mechanical. Mechanical methods include microinjection, electroporation and others. These methods have been shown to have extremely favorable transfection efficiency, which is defined as the percentage of intact plasmid DNA actively transcribed in the nucleus. However, these methods are currently not viable for large-scale cell culture because of both technical and economic reasons in their inability to scale above bench size.

Non-mechanical methods utilize calcium phosphate, cationic lipids, cationic polymers, and other nanoparticles, such as chitosan derivatives, to tightly condense DNA and form positively-charged complexes. Through electrostatic interaction with the negatively-charged cell membrane, DNA-complexes endocytose into the cytoplasm via endocytosis and eventually escape the endosomal vessicle. The DNA-complex can traffic through the cell's cytoplasm into the nucleus, or transnucleate, through various pores on the nuclear envelope or, more commonly, through the breakdown of the nuclear membrane during mitosis. During this process the DNA-complex dissociates to allow for transgene expression. Transfection efficiency is low for non-mechanical methods due to the many physico-chemical barriers the cell has developed over thousands of years of evolution to prevent foreign DNA uptake. ${ }^{60}$ However, transfection agents are believed to increase efficiency by facilitating the internalization into the 
cell and escape from endosomal/ lysosomal vesicles, as well as protecting DNA from cytoplasmic nucleic acid degredation. Each of the various transfection agents has distinct advantages and limitations, discussed below.

Developed in the late 70 's, calcium phosphate was the first transfection agent used in mammalian cells and has been subsequently optimized up to the $100-\mathrm{L}$ scale. Calcium phosphate's dependence on serum for transfection, as well as buffer exchange steps posttransfection, limit its use in large scale cell culture. ${ }^{61}$ Cationic lipid-based transfection (lipofection) has shown promise with high transfection efficiency; however, the cost of these compounds may exclude their use at large scale. Transfection methods employing cationic polymers seem to be the most actively used in the literature. Polyethelenimine (PEI) is currently the most widely used transfection agent because it is cost efficient, easy to handle and provides relatively high transfection efficiency as compared to alternative reagents. ${ }^{62}$

$\mathrm{PEI}$ is available in various configurations with average molecular weight ranging from $2-$ $750 \mathrm{kDa}$ in either branched or linear forms. The $25 \mathrm{kDa}$ linear PEI has been shown to be the optimal PEI for transfecting cells; its protocol and mechanism of delivery has been well studied. ${ }^{63,64}$ Briefly, PEI, with a high cationic charge density, condenses DNA to form a compact positively-charged particle. This particle is endocytosed, and escapes endosomal vesicles through the proton-sponge effect, in which basic nitrogen atoms become protinated and cause an influx of chloride ions which rupture the vesicle through osmotic swelling. ${ }^{65,66}$ Released plasmid DNA may transnucleate through complex methods mentioned above. Various cell types have been transfected using PEI at scales ranging from $1 \mathrm{ml}$ to $1000-\mathrm{L}$. Over the years PEI has 
proven itself to be one of the most cost effective and efficient means of DNA delivery into mammalian cells.

\subsection{Recent advances in TGE protocols}

The considerable and ever-increasing number of publications on transient transfection technologies employed for r-protein production reflects the success of this approach over the past decade. Mirroring the advances in commercial cell culture, significant process development has improved TGE titers (Table 1.3). Media development, strain modification and optimization of transfection protocols have produced process that generate up to $1 \mathrm{~g} / \mathrm{L}$ antibody quantities within two weeks. ${ }^{67}$ Many of these approaches maintain cell viability while decreasing growth rates. $^{68}$ Both hypothermia and media supplements to induce gene expression are methods that decrease growth rates, extend viability and increase titer. ${ }^{41}$ In addition, increased cell density during transfection results in both a greater utilization of DNA and produces cells with higher specific productivities. ${ }^{69}$ 


\begin{tabular}{|l|l|l|l|}
\hline Table 1.3. Antibody products produced with PEI-mediated TGE processes in mammalian cells \\
\hline $\begin{array}{l}\text { Expression } \\
\text { (mg/L) }\end{array}$ & Cell & Process Reference \\
\hline 1000 & HEK 293* & $\begin{array}{l}\text { Fed-batch, high density transfection with } \\
\text { plasmid cocktail, hypothermia and gene } \\
\text { expression additives }\end{array}$ & 67 \\
\hline 300 & CHO-S & $\begin{array}{l}\text { Batch transfection at moderate densities, } \\
\text { optimized PEI/DNA/cell ratios, } \\
\text { hypothermia }\end{array}$ & 70 \\
\hline 90 & CHO DG44 & $\begin{array}{l}\text { Use of valproic acid, hypothermia, } \\
\text { moderate transfection densities }\end{array}$ & 71 \\
\hline 80 & CHO K1SV & Fed-batch with DMSO and LiAC* & 42 \\
\hline 80 & CHO-T & $\begin{array}{l}\text { Episomal replication system, batch } \\
\text { transfection at low density }\end{array}$ & 72 \\
\hline 25 & DG44 & Low density transfection & 73 \\
\hline 22 & DG44 & Disposable orbital bioreactors & 74 \\
\hline$*$ HEK-293 cells are high producers, yet glycosylate unfavorably; DMSO (dimethyl sulfoxide); LiAC \\
(Lithium Acetate)
\end{tabular}

\subsection{Conclusions}

Rapid manufacture of full-length, human-like glycosylated antibody based medical countermeasures is an unmet medical need. Because of improvements in titer, availability of installed stainless steel and SUT capacity, and improved process performance, TGE is a viable method to meet this need. Further investigation into large scale TGE production capabilities is necessary for an optimal bio-defense strategy.

\subsection{References}

1 Casadevall A. Passive antibody administration (immediate immunity) as a specific defense against biological weapons. Emerging Infectious Diseases 2002, 8 (8) 833-41 
2 Casadevall A. Antibody-based defense strategies against biological weapons. ASM News 2005, 71 (1) 28-33

3 Defense Advanced Research Projects Agency (DARPA). Accelerated manufacturing of pharmaceuticals. BAA06-31 2006

4 Tether T. Flexible manufacturing of pharmaceuticals for biological warfare defense. Subcommittee on Defense, Committee on Appropriations, United States House of Representatives. April $24^{\text {th }} 2010$

5 Levine H. L. 2010. A World of Biomanufacturing: Shortages or global glut? BioProcess Int. Conference. Vienna, May, 2010

6 Reynolds E B. Institutions, public policy and the product life cycle: The globalization of biomanufacturing and implications for Massachusetts. Doctor of Philosophy in Urban and regional studies. MIT, February 2010

7 Hunziker E. Roche: on course through rough seas. Tokyo, November 2009

8 Croughan M. S. The silver anniversary of clinical protein production from recombinant $\mathrm{CHO}$ cells. ECl Cell Culture Engineering conference, Australia, 2008

9 Omasa T.; Onitsuka M.; Kim W.D. Cell engineering and cultivation of chinese hamster ovary (CHO) cells. Current Pharmaceutical Biotechnol. 2010 (11) 233-40

10 Hacker D. L.; De Jesus M; Wurm F. M. 25 years of recombinant proteins from reactor-grown cells. Where do we go from here? Biotechnol. Advances 2009, (27) 1023-127

11 Jagschies G. Where is biopharmaceutical manufacturing heading? BioPharm Int. 2008, 21 (10) $71-82$

12 Yang P. Y. Bioproduction Workshop. Center for Biopharmaceutical Operations. University of California at Berkeley, May $21^{\text {st }} 2008$

13 Langer E. S. Managing biopharmaceutical manufacturing capacity in 2007, changes in demand and capacity projected through 2011. BioProcess Int. March, 2008

14 De Jesus M.; Wurm F. L. Manufacturing recombinant proteins in kg-ton quantities using animal cells in bioreactors. European J. of Pharma. and Biopharma. 2011, (78) 184-8

15 Langer E. S. Trends in single-use bioproduction, what users are saying. BioProcess Int. March, 2009 
16 Eibl R. Kaiser S.; Lombriser R.; Eibl D. Disposable bioreactors: the current state-of-the-art and recommended applications in biotechnology. Appl. Microbiol. Biotechnol. 2010, (86) 41-9

17 Giroux D. Single-use bioreactors with unparalleled mixing, scalability, and ease of use. BioProcess Int. 2010, 8 (7) 130

18 DePalma A. Single-use equipment on cusp of industrialization. Genetic Engineering \& Biotechnol. News 2012, 32, (1)

19 Jefferis R. Glycosylation of recombinant antibody therapeutics. Biotechnol. Prog. 2005 (21) 11-6

20 Walsh $G$ and Jefferis R. Post-translational modification in the context of therapeutic proteins. Nat. Biotechnol. 2006, (24) 1241-52

21 Liu H.; Gaza-Bulsecon G.; Faldu D.; Chumsae C.; Sun J. Heterogeneity of monoclonal antibodies. J. Pharm Sci. 2008, 97 (7) 2426-47

22 Wu S. J.; Luo J.; O’Neil K. T.; Kang J.; Lacy E. R.; Canziani G.; Baker A.; Huang M.; Tang Q. M.; Raju T. S.; Jacobs S. A.; Teplyakov A.; Gilliland G. L.; Feng Y. Structure-based engineering of a monoclonal antibody for improved solubility. Prot. Eng. Design and Selection 2010, 23 (8) 64351

23 Kayser V.; Chennamsetty N.; Voynov V.; Forrer K.; Helk B.; Trout B. L. Glycosulation influences on the aggregation propensity of therapeutic monoclonal antibodies. J. Biotechnol. 2011,6 (1) 38-44

24 Wright $A$ and Morrison S. L. Effect of glycosylation on antibody function: implications for genetic engineering. Trends Biotechnol. 1997, 12 (1) 26-32

25 Raju T. S. and Scallon B. J. Glycosylation in the Fc domain of TgG increases resistance to proteolytic cleave by papain. Biochem. Biophys. Res. Commun. 2006 (341) 797-803

26 Raju T. S. Impact of Fc glycosylation on monoclonal antibody effector functions and degredation by proteases. Current Trends in Monoclonal Antibody Development and Manufacturing Biotechnology: Pharmaceutical Aspects, 2010, XI (6) 249-69

27 Mimura Y.; Church S.; Ghirlando R.; Ashton P. R.; Dong S.; Goodall M.; Lund J.; Jefferis R. The influence of glycosylation on the thermostability and effector function expression of human IgG1-Fc: properties of a series of truncated glycoforms. Mol. Immun. 2000, 37 (12) 697-706

28 Jefferis R. Recombinant antibody therapeutics: the impact of glycosylation on mechanisms of action. Trends Pharmacol. Sci. 2009 (30) 356-62 
29 Wright A.; Tao M. H.; Kabat E. A.; Morrison S. L. Antibody variable region glycosylation: position effects on antigen binding and carbohydrate structure. EMBO J. 1991, 10 (10) 2717-23

30 Solá $\mathrm{R}$ and Griebenow. Glycosulation of therapeutic proteins: an effective strategy to optimize efficacy. BioDrugs 2010, 24 (1) 9-21

31 Krapp S.; Mimura Y.; Jefferis R.; Huber R.; Sondermann P. Structural analysis of human IgG-Fc glycoforms reveals a correlation between glycosylation and structural integrity. J. Mol. Biol. 2003, 325 (5) 979-89.

32 Jefferis R. Glycosylation as a strategy to improve antibody based therapeutics. Nat. Rev. Drug. Discov. 2009 (8) 226-34

33 Bruhns P.; lannascoli B.; England P.; Mancardi D. A.; Fernandez N.; Jorieux S.; Daēron M. Specificity and affinity of human Fcy receptors and their polymorphic variants for human IgG subclasses. Blood 2009, 113 (16) 3716-25

34 Beck A; Wagner-Rousset E.; Bussat M. C.; Lokteff M.; Klinguer- Hamour C.; Haeuw J. F.; Goetsch L.; Wurch T.; Van Dorsselaer A.; Corvaiä N. Trends in glycosylation, glycoanalysis and glycoengineering of therapeutic antibodies and Fc-fusion proteins. Curr. Pharm. Biotechnol. 2008 (9) 482-501

35 Sethuraman N. and Stadheim T. A. Challenges in therapeutic glycoprotein production. Curr. Opin. Biotecnol. 2006, 17 (4) 341-6

36 Hossler P.; Khattak S. F.; Li Z. J. Optimal and consistent protein glycosylation in mammalian cell culture. Glycobiology 2009, 19 (9) 936-49

$37 \mathrm{Li} \mathrm{H}$. and d'Anjou M. Pharmacological significance of glycosylation in therapeutic proteins. Current Opinion in Biotechnol. 2009, (20) 678-84

38 Verma R.; Boleti E. George A. J. T. Antibody engineering: comparison of bacterial, yeast, insect and mammalian expression systems. J. Immun. Meth. 1998, 216 (1) 165-81

39 Chung C. H.; Mirakhur B.; Chan E.; Le Q. T.; Berlin J.; Morse M.; Murphy B. A.; Satinover S. M.; Hosen J.; Mauro D.; Slebos R. J.; Zhou Q. W.; Gold D.; Hatley T.; Hicklin, D. J.; Platts-Mills T. A. E. Cetuximabinduced anaphylaxis and IgE specific for galactose-alpha-1,3-galactose. N. Engl. J. Med. 2008 358, (11)1109-17

40 Durocher Y.; Perret S.; Kamen A. High-level and high-throughput recombinant protein production by transient transfection of suspention-growing human 293-EBNA1 cells. Nucleic Acids Research, 200230 (2) e9 
41 Geisse S. and Fux C. Recombinant protein production by transient gene transfer into mammalian cells. Chapter 15 in Methods in Enzymology 2009, (463) 223-38

42 Ye J.; Kober V.; Tellers M.; Naji Z.; Salmon P.; Markusen J. F.. 2008. High-Level Protein Expression in Scalable CHO Transient Transfection. Biotechnol. Bioeng. 2009 (103) 542-51

43 Zeck A.; Pohlentz G.; Schlothauer T,; Peter-Katalinić J.; Regula J. T. Cell type-specific and site directed N-glycosylation pattern of FcyRIIla. J. Proteome Res. 2011, 10 (7) 3031-9

44 Galbraith D. J.; Tait A. S.; Racher A. J.; Birch J. R.; James D. C. Control of culture environment for improved polyethylenimine-mediated transient production of recombinant monoclonal antibodies by CHO cells. Biotechnol. Prog. 2006 (22) 753-62

45 Peterson E.; Owens S. M.; Henry R. L.; Monoclonal antibody form and function: Manufacturing the right antibodies for treating drug abuse. AAPS Journal. 2006; 8 (2) E383-90

46 Jena BioSciences. Macromolecular Crystallography. Catalong No. 3. 2012

47 Reichert J. M. and Dewitz M. C. Anti-infective monoclonal antibodies: perils and promise of development. Nat. Rev. Drug Discov. 2006 (5) 191-5

48 Berry J. D. and Gaudet R. G. Antibodies in infectious diseases: polycloncals, monoclonals, and niche biotechnology. New Biotechnol. 2011, 28 (5) 489-501

49 Marks J. D. Deciphering antibody properties that lead to potent botulinum neurotoxin neutralization. Movement Disorders 2004, 19 (S8) S101-8

50 Reichert J. M.; Rosenweig C. J.; Faden L. B.; Dewitz M. C. Monoclonal antibody successes in the clinic. Nat. Biotechnol. 2005 (23) 1073-8

51 Daēron M. Fc receptor biology. Annu. Rev. Immunol. 1997, (15) 203-34

52 Abboud N.; Chow S. K.; Saylor C.; Janda A.; Ravetch J. V.; Scharff M. D.; Casadevall A. 2010. A requirement for FcyR in antibody mediated bacterial toxin neutralization. J. Exp. Med. 2010, 207 (11) 2395-405

53 Sepulveda J.; Mukherjee J.; Tzipori S.; Simpson L. L.; Shoemaker C. B. Efficient serum clearance of botulinum neurotoxin achieved using a pool of small antitoxin binding agents. Infection and Immunity 2010, 756-63

54 Wurm F. M. and Bernard A. Large-scale transient expression in mammalian cells for recombinant protein production. Curr. Opin. Biotechnol. 1999, 10 (2) 156-9 
55 Chu L. and Robinson D. K. Industrial choices for protein production by large-scale cell culture. Current Opin. in Biotechnol. 2010, 12 (2) 180-7

56 Li F.; Vijayasankaran N.; Shen Y.; Kiss R.; Amanulla A. Cell culture processes for monoclonal antibody production. MAb. 2010, 2(5) 466-77

57 Wurm F. M. 2004. Production of recombinant protein therapeutics in cultivated mammalian cells. Nat. Biotechnol. 2004, 22 (11) 1393-8

58 Kelly B. Very Large Scale Monoclonal Antibody Purification: The Case for Conventional Unit Operations. Biotechnol. Prog. 2007, 23, 995-1008

59 Varga CM, Tedford NC, Thomas M, Klibanov AM, Griffith LG, Lauffenburger DA (2005) Quantitative comparison of polyethylenimine formulations and adenoviral vectors in terms of intracellular gene delivery processes. Gen Ther 12:1023-1032

60 Wiethoff C. M. and Middaugh C. R. Barriers to nonviral gene delivery. J Pharm Sci 2003, 92(2) 203-17

61 Jordan M.; Schallhorn A.; Wurm F. M. Transfecting mammalian cells: optimization of critical parameters affecting calcium-phosphate precipitate formation. Nucleic Acids Res. 1996, 24 (4) 596-601

62 Fischer D.; Bieber T.; Li Y.; Elsasser H. P.; Kissel T. A novel non-viral vector fornDNA delivery based on low molecular weight, branched polyethylenimine: effect of molecular weight on transfection efficiency and cytotoxicity. Pharm. Res. 1999, 16 (8) 1273-9

63 Boussif O.; Lezoualch F.; Zanta M. A.; Mergny M. D.; Scherman D.; Demeneix B.; Behr J. P. A versatile vector for gene and oligonucleotide transfer into cells in culture and in vivo: polyethylenimine. Proc. Natl. Acad. Sci. 1995, 92 (16) 7297-301

64 Bertschinger M.; Backliwal G.; Schertenleib A.; Jordan M.; Hacker D. L.; Wurm F. M. Disassembly of polyethylenimine-DNA particles in vitro: implications for polyethyleniminemediated DNA delivery. J. Control Release 2006, 116 (1) 96-104

65 Akinc A.; Thomas M.; Klibanov A. M.; Langer R. Exploring polyethylenimine-mediated DNA transfection and the proton sponge hypothesis. J. Gene. Med. 2005, 7 (5)657-63

66 Thomas M. and Klibanov A. M. Non-viral gene therapy: polycation-mediated DNA delivery. Appl. Microbiol. Biotechnol. 2003, 62 (1) 27-34

67 Backliwal G, Hildinger M,Chenuet S, Wulhfard S, Jesus MD, Wurm FM. Rational vector design an multi-pathway modulation of HEK 293E cells yield recombinant antibody titers exceeding 1 
g/I by transient transfection under serum-free conditions. Nucleic Acids Research 2008, 36 (15) e96

68 Geisse S. Reflections of more than 10 years of TGE approaches. Protein Expression and Purification 2009 (64) 99-107

69 Baldi L.; Hacker D. L.; Adam M.; Wurm F. M. Recombinant protein production by large-scale transient gene expression in mammalian cells: state of the art and future perspectives. Biotechnol. Lett. 2007, 29 (5) 677-84

70 Rajendra Y.; Kiseljak D.; Baldi L.; Hacker D. L.; Wurm F. M. A simple high-yielding process for transient gene expression in CHO cells. J. Biotechnol. 2011 (153) 22-6

71 Wulhfard S.; Baldi L.; Hacker D. L.; Wurm F. M. Valporic acid enhances recombinant mRNA and protein levels in transiently transfected Chinese hamster ovary cells. J. Biotechnol. 2010, $148(2-3) 128-32$

72 Codamo J. Hou J. J. C.; Hughes B. S.; Gray P. P.; Munro T. P. Efficient mAb production in CHO cells incorporating PEI-mediated transfection, mild hypothermia and the co-expression of XBP1. J Chem Technol Biotechnol. 2011 (86) 923-34

73 Pham P. L.; Kamen A.; Durocher Y. Large-scale transfection of mammalian cells for the fast production of recombinant protein. Mol. Biotechnol. 2006, 34 (2) 225-37

74 Muller N.; Derouazi M.; Tilborgh F. V.; Wulhfard S.; Hacker D. L.; Jordan M.; Wurm F. M. Scalable transient gene expression in Chinese hamster ovary cells in instrumented and noninstrumented cultivation systems. Biotechnol. Lett. 2007, 29 (5) 703-11 


\title{
CHAPTER 2. ENGINEERING CONSIDERATIONS FOR LARGE SCALE TRANSIENT GENE EXPRESSION OF MONOCLONAL ANTIBODIES IN CHO CELL CULTURE
}

\author{
Abstract \\ Transient gene expression could potentially provide sufficient quantities of full-length, human- \\ like monoclonal antibodies as medical countermeasures in the event of mass casualty biological \\ catastrophe. This rapid method of protein production has been scaled to hundreds of liters to \\ provide gram scale quantities of research-grade protein, yet further increases in scale are \\ needed to fulfill rapid response needs. Many transient operations parallel those found in stable \\ gene expression, which have been successfully scaled up to $25,000 \mathrm{~L}$. This work aims to \\ characterize aspects of transient gene expression that are distinct from those found in stable \\ expression and key to the scale-up of TGE production. A concentration dependent transport \\ model was constructed to evaluate potential mass transfer limitations which may be \\ encountered upon scale-up. As a critical component of this model, PEI/DNA particles were \\ characterized through dynamic light scattering and were found to be larger and more complex \\ than previously reported. The mass transport model helped explain certain complex trends that \\ involve trade-offs between the cytotoxicity of PEI/DNA polyplexes and the specific productivity \\ of transfected cells. The model also predicted the impact of mixing and diffusion limited \\ polyplex transport upon scale up to industrial sized bioreactors.
}




\subsection{Introduction}

Transient gene expression (TGE) has become a standard method for rapid production of milligram to gram quantities of recombinant protein ( $r$-protein). The need for $r$-proteins with post-translational modifications, including monoclonal antibodies, has fostered the development of mammalian-cell based transient expression systems (Durocher and Butler 2009). ${ }^{1}$ While transfection protocols have yet to be standardized, suspension-adapted mammalian cells, especially Chinese hamster ovary (CHO) and Human Embryonic Kidney- 293 (HEK-293) cells, have dominated the literature. For HEK-293 cells, titers up to $1 \mathrm{~g} / \mathrm{L}$ monoclonal antibody have been reported (Backliwal et al. 2008), ${ }^{2}$ while CHO processes report 20-300 mg/L in batch cultures (Rajendra et al. 2011; Pham et al. 2006; Baldi et al. 2007; Galbraith et al. 2006). ${ }^{3-6}$ Many of these processes employ high density cultures $\left(20^{*} 10^{6}\right.$ cells $\left./ \mathrm{ml}\right)$, direct addition of plasmid DNA and linear $25 \mathrm{kDa}$ polyethylenimine (PEI), followed by a feed of both production media and additives to increase gene expression. These high-density methods, however, have not been scale-up to bioreactors larger than a few liters. Current TGE protocols do not meet rapid response needs of bio-defense, and an unmet medical need still exists.

Stable gene expression (SGE) in $\mathrm{CHO}$ cells, on the other hand, has been employed for dozens of FDA-approved therapeutic molecules including monoclonal antibodies at large scales (Geisse 2009). ${ }^{7}$ Production processes have been rigorously characterized and optimized up to the 25,000 L scale. Critical operations in SGE r-protein production include; expansion of inoculum from frozen cell vials, media exchange of spent media prior to production phase (for some processes), cell cultivation in production bioreactors, which includes: $\mathrm{pH}$ control with base addition, DO control with sparged gas, removal of $\mathrm{CO} 2$ with sparged gas, nutrient addition 
(fed-batch), and backpressure control (Table 2.1). For many cell cultures operations, TGE employs the same techniques as SGE, and is therefore likely to be successfully scaled without difficulty. There are, however, differences encountered between the two expression methods, Table 2.1 identifies these similarities and differences. One goal of this study was to investigate how the operations unique to TGE may be affected by scale and predict the success of largescale TGE production.

Table 2.1. Large-scale CHO cell culture in stirred tanks

\begin{tabular}{|c|c|c|}
\hline Unit Operation & SGE & TGE \\
\hline $\begin{array}{l}\text { Expansion of inoculum } \\
\text { from frozen cell vials up to } \\
5000-\mathrm{L}\end{array}$ & Well established & Likely same as SGE \\
\hline $\begin{array}{l}\text { Media exchange of spent } \\
\text { media prior to production } \\
\text { phase }\end{array}$ & $\begin{array}{c}\text { Successfully employed at } \\
2400-L \text { N-1 scale for } \\
\text { certain processes }\end{array}$ & $\begin{array}{c}\text { Possible scale-up to larger } \\
\text { systems }\end{array}$ \\
\hline $\begin{array}{c}\text { Cell cultivation in } \\
\text { production bioreactor up } \\
\text { to } 25,000 \text {-L Scale }\end{array}$ & Well established & Likely same as SGE \\
\hline $\begin{array}{l}\mathrm{pH} \text { control with bulk } \\
\text { mixing of added base }\end{array}$ & Well established & Likely same as SGE \\
\hline $\begin{array}{l}\text { DO control with sparged } \\
\text { gases (air and oxygen) }\end{array}$ & Well established & Likely same as SGE \\
\hline $\begin{array}{c}\text { Removal of } \mathrm{CO}_{2} \text { with } \\
\text { sparged gasses }\end{array}$ & Well established & Likely same as SGE \\
\hline $\begin{array}{l}\text { Nutrient additions } \\
\text { through fed-batch }\end{array}$ & Well established & Likely same as SGE \\
\hline Backpressure control & Well established & Likely same as SGE \\
\hline $\begin{array}{l}\text { Transfection of cells with } \\
\text { pDNA and PEI at 2500- } \\
\text { 5000-L Scale }\end{array}$ & N/A & $\begin{array}{l}\text { Explored in this article } \\
\text { using engineering analysis } \\
\text { and experimentally using } \\
\text { scale down models }\end{array}$ \\
\hline $\begin{array}{l}\text { Cultivation of recently } \\
\text { transfected cells at scales } \\
\text { up to } 25,000-\mathrm{L}\end{array}$ & N/A & $\begin{array}{c}\text { Recently transfected cells } \\
\text { may be more shear- } \\
\text { sensitive than standard } \\
\text { SGE CHO }\end{array}$ \\
\hline
\end{tabular}

TGE unit operations that differ from standard SGE include media exchange of spent media prior to production, transfection of cells with plasmid DNA and PEI, and maintenance of transfected cells. Media exchange has been employed at the 2,400 L scale for commercial 
production of certain r-proteins and is not likely to differ for transient systems. Similarly, cultivation of transfected cells is most likely not significantly different from high density SGE cultivation beyond a possible increase in shear sensitivity. Transfection of cells is the primary step that may be affected by scale. Transfection at larger scales may be influenced by a number of factors including DNA/PEI nanoparticle formation, (polyplex formation), bulk mixing, polyplex transport to the surface of the cell, and hydrodynamic forces acting on the cells during transfection.

Many of these interrelated phenomena are impacted by aeration and agitation and are critical factors for animal cell cultivation. Scale-up tradeoffs between various agitation and aeration regimes have been rigorously studied for stable cell culture (Dusting et al. 2006; Garcia-Ochoa and Gomez 2009; Zhang et al. 2010) ${ }^{8-10}$ Increases in scale typically result in both an increase in heterogeneity of shear forces, fluid velocities, circulation times in stagnant zones, and mixing times, as well as a decrease in the smallest Kolmogorov eddy length (Lara et al. 2006; Xing et al. 2009; Tissot et al. 2010). ${ }^{11-13}$

PEI-mediated TGE is composed of a number of steps, illustrated in Figure 2.1. The steps are a combination of both chemo-physical phenomena that can be modeled using concentration dependent mass transfer equations, and biological processes that are related to cell physiology and health. Scale-up of mixing and agitation equipment for large-scale transfections could impact process performance at the cellular level in a number of ways. These factors could influence transfection by altering: (1) the complex formation rates; (2) mass transfer of polyplexes from the culture medium to the cell surface; (3) internalization rates of polyplexes; (4) the hydrodynamic stresses on the cell; or (5\&6) the physiological health of cells 
in less defined ways. Many of these effects occur simultaneously, resulting in tradeoffs and intermediate optima.

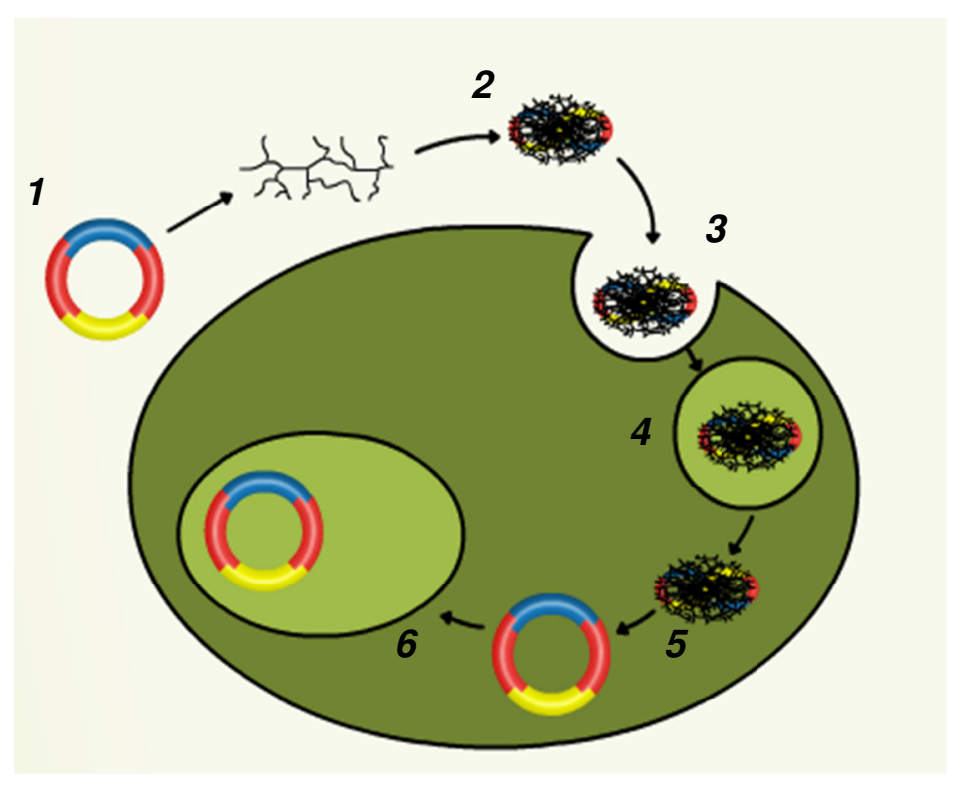

Figure 2.1. Overview of the transfection process.

(1) DNA condensation through electrostatic interactions with transfection agent. (2) This interaction will eventually form a stable polyplex. (3) Polyplexes transport to the surface of the cell and are internalized through various nonspecific endocytosis mechanisms. (4) Complexes eventually escape endocytotic vesicles through the proton sponge effect. (5) DNA is liberated from the complex. (6) Intact DNA is transported to the nucleus through complex, and unclear mechanisms. Once plasmid DNA enters the nucleus it is transcribed and translated for protein production.

\subsubsection{Optimal DNA per cell}

One important aspect of transfection is the amount of DNA entering each cell. Too much DNA entry and cytotoxic effects are observed. (Fischer et al. 1999; Godbey et al. 2001; Godbey and Mikos, 2001; Godbey et al. 2001; Putnam and Langer, 1999; Rajendra et al. 2011; Biollin et al. 2011). ${ }^{4,38-43}$ This cytotoxicity is caused either by foreign gene responses, cellular membrane disruption, endosomal swelling and rupture, or autophagy (Fischer et al. 1999; Beyerke et al. 2010; Gao et al. 2011). ${ }^{38,44,45}$ While too much DNA entry to the cell is cytotoxic and suboptimal, too little DNA entering the cell is also suboptimal. Too little DNA entering the 
cell does not provide a cell with sufficient capability to produce protein in high levels (high specific productivity, $Q_{p}$ ). Therefore, there is an optimal range of the amount of DNA entering each cell, shown in Figure 2.2.

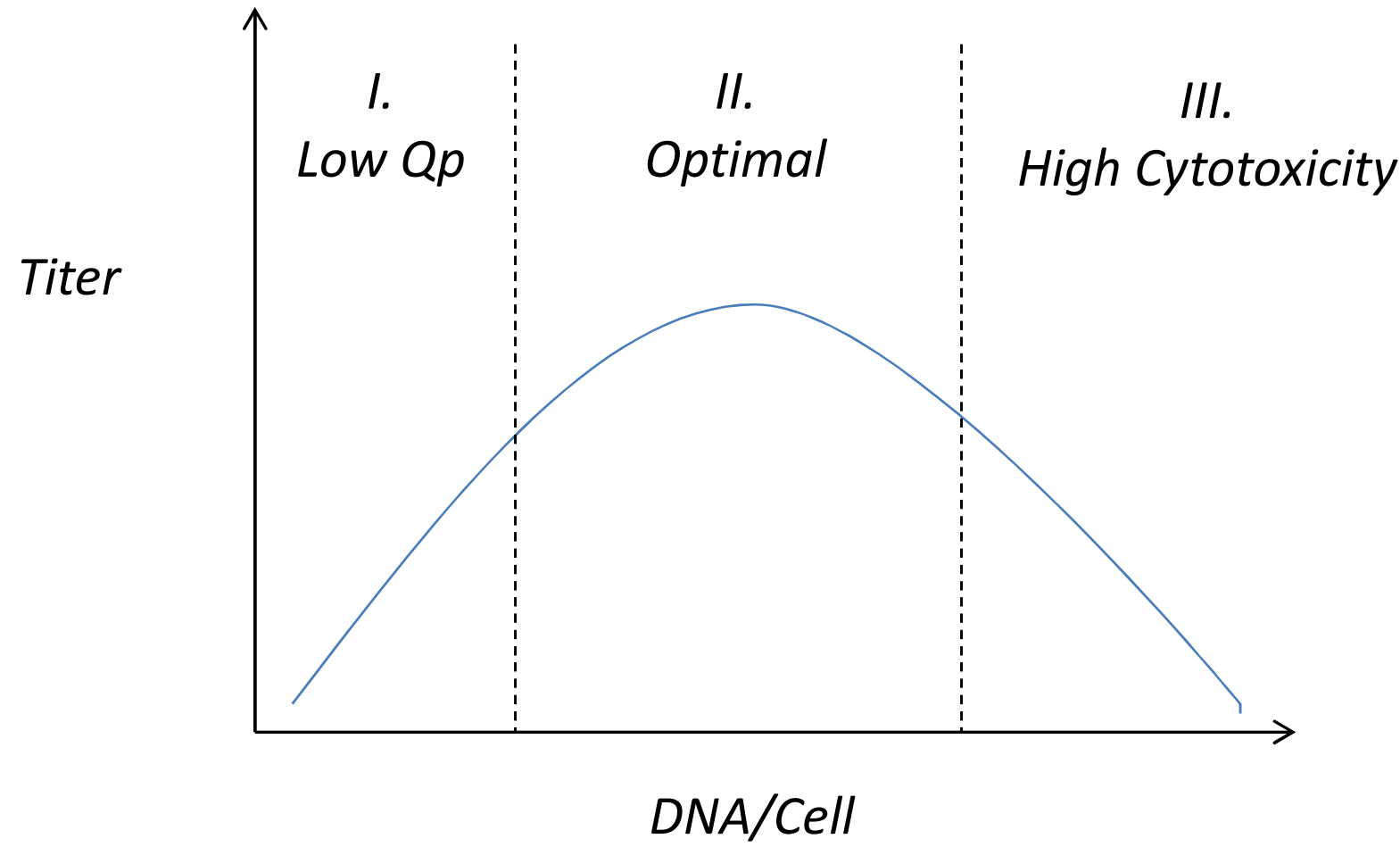

Figure 2.2. Dose-dependent cytotoxicity and specific productivity of PEI mediated TGE.

The blue line represent the results from transfections. Each section on the graph represent a scenario characterized by either I. Too little DNA/cell and transfected cells lack sufficient productivity; II. an optimal transfection paradigm; III. Too much DNA/cell and transfected cells die.

\subsubsection{Transport}

The amount of DNA entering the cell is a function of the hydrodynamic environment that surrounds the cell. DNA found in the bulk culture fluid is internalized by a cell only when in proximity to the surface of the cell. DNA particles are transported to the surface of a cell in a concentration dependent manor by a combination of diffusive and convective forces. One goal of this study was to construct a mass transport model and investigate the scalability of TGE. 
While a number of phenomenological observations have been made governing the kinetics and mechanics of PEI mediated gene transfer, a phenomenological model including hydrodynamic effects on mass transfer has not been proposed. Viral mediated gene transfer, on the other hand, has been studied for over 50 years and several complex-attachment based mass transfer models have been proposed (Tang and Szoka 1997; Orgis et al. 1998; Goula et al. 1998; Godbey et al. 1999. Bertschinger et al. 2008; Hufnagel et al. 2009; Han et al. 2009; Palumbo et al. 2012). ${ }^{14-21}$ Transport of viral particles from the bulk culture fluid to the cell is a relatively slow process compared to the transport of proteins or nutrients, due to larger particle sizes and lower diffusivity coefficients. It is now generally accepted that virus-cell contact can be represented by a simple diffusion controlled process through an exponential decay function with various corrective factors (Chillakuru et al. 1991; Mittereder et al. 1996; Nyberg-Hoffman et al. 1997; Chuck et al. 1996; Gilbert et al. 2007; Tayi et al. 2010). ${ }^{22-27}$ This work similarly employed an expediential decay function based off of the size of polyplex in a turbulent cell culture vessel to explain results from transfection experiments in shaker flasks and predict the scalability of transfection.

\subsubsection{Model construction}

Concentration dependent mass transfer analysis was conducted for a model system composed of a homogeneous suspension of $\mathrm{CHO}$ cells in chemically defined media in a stirred tank bioreactor agitated by an impeller (e.g., Rushton or pitched-blade), which rotates at a set stirrer speed. Most studies involving macroscopic diffusion of spherical, membrane-adsorbing particles assume diffusion occurs in a semi-infinite stagnant film around each cell and that 
adsorption on the cell surface is both instantaneous and irreversible. Therefore the diffusivity coefficient $\left(D_{\mathrm{F}}\right)$ can be calculated through the Stokes-Einstein equation (Doran 1995) ${ }^{30}$

$$
D_{F}=\frac{k_{B} T}{6 \pi \eta r}
$$

Where $k_{B}$ is the Boltzmann's constant $\left(1.38^{*} 10^{-23} \mathrm{JK}^{-1}\right), T$ is the absolute temperature $\left(310^{\circ} \mathrm{K}\right), \eta$ is the fluid viscosity for protein-free medium $\left(7.1 * 10^{-3} \mathrm{~g} / \mathrm{cm}-\mathrm{sec} \text {; Anunins and Henzler 1988) }\right)^{31}$ and $r$ is the particle radius. For a PEI/DNA complex suspended in a turbulent vessel, mass transport of the complex from the bulk medium to the cells can be described by a dimensionless Sherwood number (Doran, 1995). ${ }^{30}$ For transport to spheres such as cells in turbulent vessels, one can use the following equation put forth by (Sano et al. 1974; Chaudhari and Ramachandran 1980)..$^{31,32}$

$S h=2+0.4\left(\frac{\varepsilon D_{c}{ }^{4}}{D_{F} v^{2}}\right)^{1 / 3}$

Where Sh is the Sherwood number, $\varepsilon$ is the average power dissipation per unit mass ( assumed to be $100 \mathrm{~cm}^{2} / \mathrm{sec}^{3}$ ), $D_{c}$ is the diameter of a CHO cell (assumed to be $15 \mu \mathrm{m}$ ) and $v$ is the kinematic viscosity $\left(7.03 * 10^{-3} \mathrm{~cm}^{2} / \mathrm{sec}\right)$. For liquid phase transport, the Sherwood number can be written as the ratio of overall to diffusive mass-transfer rates through the boundary layer to a spherical cell, or

$S h=k_{L} \frac{D_{c}}{D_{F}}$

Where $k_{L}$ is the liquid phase mass transfer coefficient. Near the cell-liquid interface, the fluid velocity is reduced and a boundary layer develops. If the particle is immediately internalized by the cell $\left(C_{i}=0\right)$, the concentration difference between the bulk liquid and the phase interface drives mass transfer of the particle from the liquid to the cell within time $\Delta t$, described by 
$C_{0}=C_{0,1} e^{-k_{L} a(\Delta \mathrm{t})}$

Where $C_{0}$ is the concentration of the particle in the bulk liquid and $C_{i}$ is the particle concentration at the cell surface, $a$ is the liquid-solid interfacial area per unit volume described by $a=4 \pi D_{c}^{2} X$, where $X$ is the cell density in the fluid $\left(20^{*} 10^{6}\right.$ cell $\left./ \mathrm{ml}\right)$. Therefore the rate of change of the complex concentration in a turbulent, vessel between two time points $\left(t_{1}\right.$ and $t_{2}$, where $t_{2}>t_{1}$ ) can be mathematically represented by

$C_{0}=C_{0,1} e^{-\frac{S h D_{F}}{2 D_{C}} 4 \pi D_{C}^{2} X\left(t_{2}-t_{1}\right)}$

For simplification, the half-life of polyplexes in the bulk media can be estimated as

$k_{d}=\frac{\ln 2}{\frac{\operatorname{ShD}_{\mathrm{F}}}{2 D_{c}} 4 \pi \mathrm{D}_{\mathrm{c}}^{2} X}$

These equations were simulated using Microsoft Excel 2010 using best parameter estimates from experimental observations. After constructing the model, mass transport of polyplexes was calculated while varying certain parameters, such as polyplex size, cell density, and agitation in order to investigate their effect on transfection.

\subsubsection{Calculate polyplex size effect on mass transport}

The size of the polyplex would alter its diffusivity coefficient. Using Equation 1, a range of polyplex diffusivity coefficients were calculated. Polyplex diameters of $60-2000 \mathrm{~nm}$ were modeled, whose $D_{F}$ ranged from $5.33 * 10^{-9}$ to $1.60 * 10^{-10} \mathrm{~cm}^{2} / \mathrm{sec}$. This range of $D_{F}$ was used to calculate mass transfer rates based off of a Sherwood analysis with Equation 6 . The Sherwood number was 2.4 with an assumed power input of $100 \mathrm{~cm}^{2} \mathrm{~s}^{-1}$. A substantial increase in half-life, or $K_{d}$, was observed with increasing polyplex size (Figure 2.3). This $K_{d}$ represents the time scale 
when half of the plasmids arrive at the cell surface and was calculated to be between 30 seconds and 5 minutes with larger polyplexes arriving at a slower rate than smaller polyplexes.

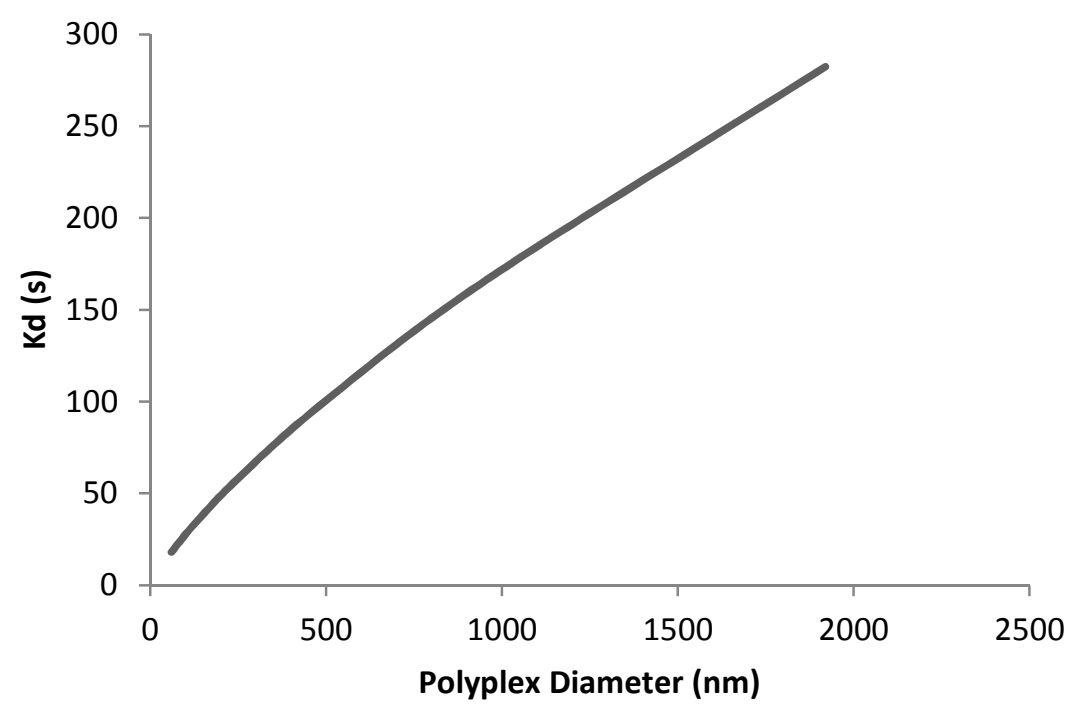

Figure 2.3. Calculated tansport of polyplexes versus size.

Calculated effect of polyplex size of mass transfer rates using assumptions listed in model construction section.

\subsubsection{Calculate cell density effect on mass transport}

Many groups have investigated the ratio of Cell/DNA/PEI and found conflicting optimal ranges (Codamo et al. 2010, Backliwal et al. 2008, Rajendra et al. 2011). ${ }^{3,437}$ In order to understand cell concentration's effect on transfection, mass transport of polyplexes to the cell surface was modeled by varying cell density from 1 to 30 million cells per $\mathrm{ml}$ (Figure 2.4). While holding DNA:PEl constant and varying cell concentration, polyplex per cell changes or $X$ in Equation 6. Low density cultures have large time scales $\left(K_{d}\right)$ for polyplex transport, approximately 1 hour, whereas high density cultures have much shorter time scales, under two minutes. There was a steep decline in $K_{d}$ as the cell density increased between 1 and 10 million cells per $\mathrm{ml}$. Increases beyond 10 million cells per $\mathrm{ml}$, displayed a marginal decreases in $\mathrm{K}_{\mathrm{d}}$. These observations indicate that a polyplex diffusion limitation may exist during transfections. 
An observation that highest titer transfection processes employ high density transfections further confirms the mass transport model. (Backliwal et al. 2008). ${ }^{4}$

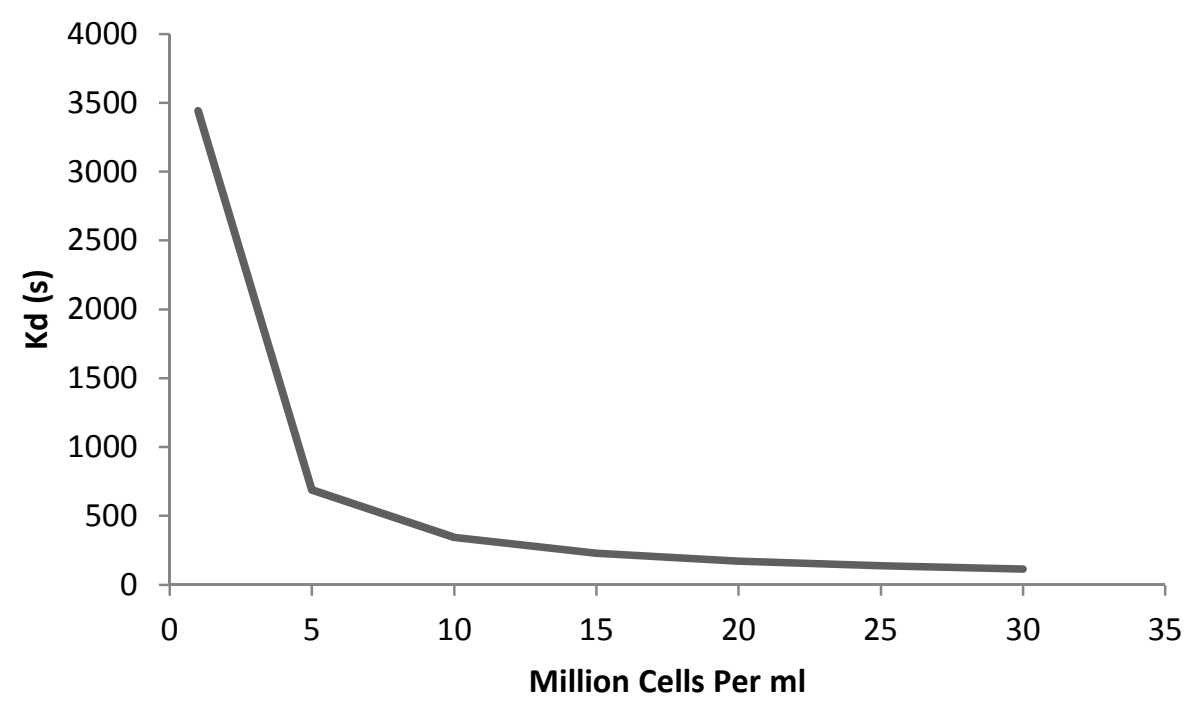

Figure 2.4. Calculated cell density effect on transfection.

Mass transport of polyplexes were modeled using a range of cell densities $(X)$ using equation 6.

\subsubsection{Calculate agitation effect on mass transport}

Increase in agitation would affect polyplex formation rates as well as increase the convective force driving mass transport. Increase in agitation would increase power dissipation per unit mass $(\varepsilon)$, thus influence the Sherwood number Equation 3. $\varepsilon$ has not been rigorously calculated for $125 \mathrm{ml}$ shaker flasks, but approximate values have been predicted between 5 and $35 \mathrm{~W} \mathrm{~m}^{-3}$ (Barrett et al. 2010). In a $30 \mathrm{ml}$ culture, the associated $\varepsilon$ values range from 1500 and $10500 \mathrm{~cm}^{2} \mathrm{~s}^{-3}$. A wide range of values for $\varepsilon$ were modeled and the half-life of complexes in the bulk media was predicted using Equation 6 (Figure 2.5). There was an exponential relationship between agitation and time scale of complex arrival at the cell surface. Increases in agitation enhance mass transport during transfection. 


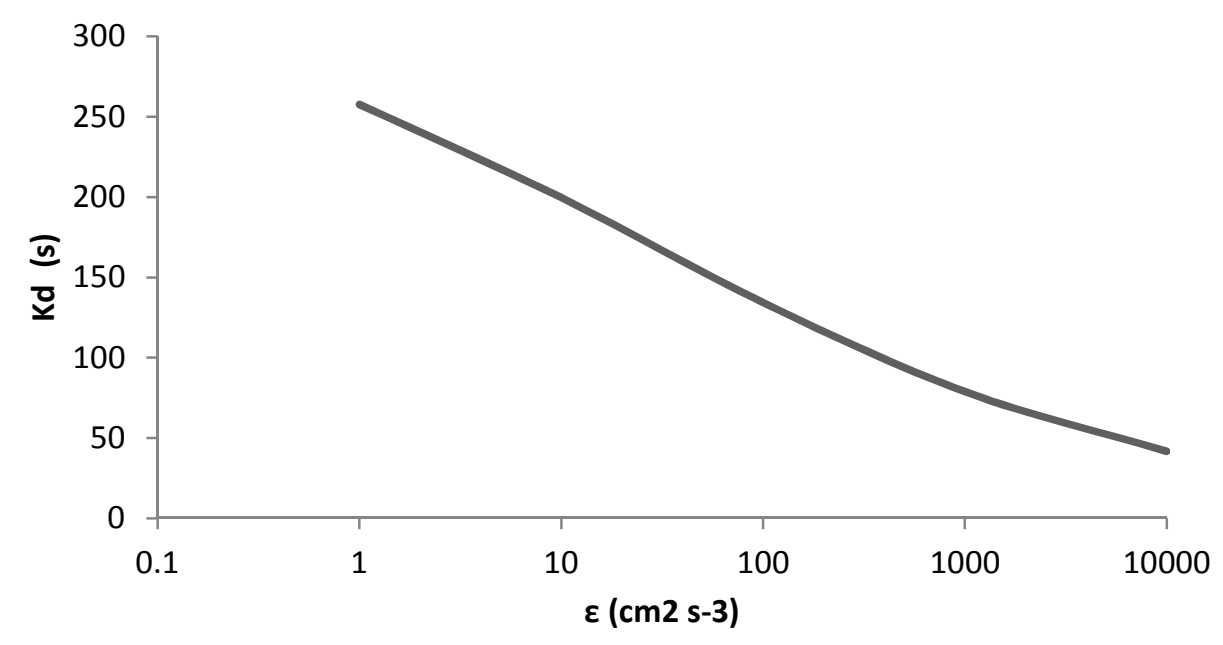

Figure 2.5. Calculated effect of agitation on polyplex mass transfer.

A $30 \mathrm{ml}$ shaker flask with a range of power dissipation rates was used to model the mass transfer rate of a $600 \mathrm{~nm}$ polyplex.

\subsubsection{Bulk mixing and scale-up considerations}

Bulk mixing is important to ensure a macroscopic-level homogenous concentration of nutrients, cells, gases and polyplexes through the bioreactor. In shaker flasks, time scales for mixing are very short $(<0.1 \mathrm{~min})$. Larger bioreactors $\left(1-100 \mathrm{~m}^{3}\right)$, however, have much larger mixing times, on the order of 0.5-2 minutes (Doran 1995). ${ }^{30}$ Bulk mixing is most likely not a limitation of polyplex transport in shaker flasks, but may affect mass transport in larger bioreactors. A comparison of mixing times at various scales is illustrated in Table 2.2. Using equation 6 with a range of sizes for polyplexes, we calculated the ratio of times scales, which indicate time scales of bulk mixing in industrial bioreactors is larger than the time scale of diffusion for the smallest size polyplexes, and is equivalent to that for medium sized polyplexes. Therefore, bulk mixing time is a parameter that must be considered for large scale bioreactors. Nevertheless, the time scales for the biological processes related to transfection, such as polyplex uptake, intracellular polyplex trafficking, transnucleation and transcription are much 
greater than 30 minutes, and much longer than the times scales for bulk mixing or diffusion of the polyplex from the medium to the cell. Therefore, the slower mixing upon scale-up of agitation and aeration for larger scale bioreactors most likely would not negatively affect the transfection process.

Table 2.2. Time scales for various transfection operations

\begin{tabular}{|ccc|}
\hline Pulk mixing of transfection & Condition & Time \\
reagents & Shakers & $<0.1 \mathrm{~min}$ \\
\cline { 2 - 3 } & Lab-scale Bioreactors & $<0.5 \mathrm{~min}$ \\
\cline { 2 - 3 } & Industrial Bioreactors $\left(1-25 \mathrm{~m}^{3}\right)$ & $0.5-2.0 \mathrm{~min}$ \\
\hline $\begin{array}{c}\text { Diffusion of polyplex from } \\
\text { media to cell, immediate } \\
\left.\text { absorption (with } \mathbf{C}_{\mathbf{i}}=\mathbf{0}\right)\end{array}$ & polyplex size $=1200 \mathrm{~nm}$ & $<3 \mathrm{~min}$ \\
\cline { 2 - 3 } & polyplex size $=600 \mathrm{~nm}$ & $<1.5 \mathrm{~min}$ \\
\hline $\begin{array}{c}\text { Biological processes related to } \\
\text { transfection (uptake, } \\
\text { intracellular trafficking, etc...) }\end{array}$ & polyplex size $=70 \mathrm{~nm}$ & $<0.5 \mathrm{~min}$ \\
\hline
\end{tabular}

\subsection{Materials and methods}

\subsubsection{Plasmid constructs}

The 8118 base pair plasmid used in this study was p6G4V11N35E.choSD.10 (ATCC -HB-11722), which encodes for a humanized IgG antibody. Plasmids were purchased from a commercial vendor (Nature Technology Corporation, Lincoln NA).

\subsubsection{Cell culture}

Experiments were conducted with Freestyle CHO-S cells (Life Technologies, San Diego, CA), a $\mathrm{CHO}$ line derived from $\mathrm{CHO}-\mathrm{K} 1$ that is pre-adapted to chemically defined, suspension culture (Deaven \& Petersen 1973; D'Anna 1996; D'Anna et al. 1997). ${ }^{28-30}$ Cells were cultured in either 
chemically defined ProCHO5 media (Lonza, Basel, Switzerland) supplemented with $4.1 \mathrm{mM} \mathrm{L-}$ glutamine, HT supplement (Life Technologies) or OptiCHO media (Life Technologies) supplemented with $8 \mathrm{mM}$ L-glutamine. Cells were passaged every 3-4 days at densities ranging from $0.3 * 10^{6}$ cells $/ \mathrm{ml}$ to $5.0 * 10^{6}$ cells $/ \mathrm{ml}$ (more dense passaging was used for inoculum expansion). Cells were cultivated in $125 \mathrm{ml}$ shaker flasks (Corning) operated at $30 \mathrm{mls}$ of culture volume, placed in a large, humidified incubator (Thermofisher) at $37^{\circ} \mathrm{C}, 8 \% \mathrm{CO}_{2}$. The shaker cultures were agitated on a rotary shaker (New Brunswick) at $130 \mathrm{rpm}$.

\subsubsection{Shaker flask transfections}

Cells were transfected in $125 \mathrm{ml}$ shaker flasks using a modified XLG protocol (Backliwal et al. 2008). Expanded inoculum was centrifuged prior to transfection and, if not otherwise specified resuspended at a cell density of $20^{*} 10^{6}$ cells $/ \mathrm{ml}$ in ProCHO5 media. DNA was added to a final concentration of $50 \mu \mathrm{g} / \mathrm{ml}$ directly to the cells. This was immediately followed by addition of the appropriate amount of a $1 \mathrm{mg} / \mathrm{ml}$ solution of $25-\mathrm{kDa}$ polyethyleneimine (PEl; Polysciences) to a final concentration of $100 \mu \mathrm{g} / \mathrm{ml}$. 3 hours after transfection, cells were diluted with fresh media supplemented with $3.8 \mathrm{mM}$ valproic acid to final cell density of $4 * 10^{6}$ cells $/ \mathrm{ml}$. Cultures were performed in triplicate and maintained with agitation at $31^{\circ} \mathrm{C}$ for up to 10 days.

\subsubsection{Cell, protein and metabolite analysis}

Viable cell density (VCD), viability, and cell size were determined using a Beckman Coulter ViCell Viability Analyzer (Beckman Coulter). Supernatant samples were centrifuged, and then stored at $-80^{\circ} \mathrm{C}$ for further analysis. Integrated viable cell density, determined from the sum of interval contributions, where each contribution was calculated using:

$\frac{V C D_{t 2}+V C D_{t 1}}{2} *(t 2-t 1)$ 
Where $\mathrm{VCD}_{\mathrm{tx}}$ is the viable cell density at time $\mathrm{x}$ in million cells per $\mathrm{ml}$, and $\mathrm{t}$ is the time in hours.

The antibody $(\lg G)$ concentration in the culture medium was determined by sandwich ELISA as

previously described (Meissner et al., 2001; Pick et al. 2002). ${ }^{28,29}$ In short, goat anti-human Fc (Sigma, St. Louis, MN) was used for coating the ELISA - plates, and the synthesized IgG protein was detected with horse radish peroxidase (HRP)-conjugated goat anti-human IgG-Fc (Sigma). OPD (Sigma) was used as a substrate for the HRP. Absorption was measured at $450 \mathrm{~nm}$ using a microplate reader (SPECTRAmax340; BioRad, Herceles, CA). Specific productivity $\left(Q_{p}\right)$ was calculated as titer/IVCD.

\subsubsection{Polyplex sizing}

Polyplex size was determined by dynamic light scattering (DLS). Complexes were formed in a 50 $\mathrm{ml}$ falcon tube (BD biosciences, San Jose, CA, USA) with $25 \mu \mathrm{g}$ DNA and $50 \mu \mathrm{g}$ PEI in a volume of $500 \mathrm{ml}$ of either water, or ProCHO5 media. Samples were subjected to agitation on an orbital rotating platform for five minutes before aliquoting into a cuvette and measuring size with a Malvern Nanosizer (Brookhaven, Holtsville, NY, USA). Laser wavelength was $514.5 \mathrm{~nm}$ and carried out at a fixed angle of $90^{\circ}$. Measurement times were automatically calculated by the nanosizer. The approximate molecular weight (MW) of DNA mass was calculated using an online nucleic acid algorithm for double stranded DNA from (Life Technologies).

\subsection{Results and discussion}

\subsubsection{Particle size of DNA/PEI complexes in room temperature agitated media}

In order to characterize DNA/PEI transfection particles in cell culture, polyplex size in ProCHO5 culture medium was examined as a function of agitation in spin tubes. Polyplexes 
were formed by agitating a DNA/PEl/media solution for 5 minutes at either 100 or $200 \mathrm{rpm}$ in conical falcon tubes at room temperature before measuring with DLS. Neither media with just PEI nor media with just DNA provided measureable particles. Therefore, any observed particles in DNA/PEI/media were the result of DNA/PEI complexes. As a control, polyplexes were tested in water and were $60 \pm 7 \mathrm{~nm}$ (Figure 2.6A). This result is in good agreement with the $57 \pm 14 \mathrm{~nm}$ size particles determined by other light scattering measurements (Blessing et al. 2001) ${ }^{33}$ and $70 \pm 10 \mathrm{~nm}$ size particles determined by two photon fluorescence correlation spectroscopy (Clamme et al. 2003). ${ }^{34} \mathrm{~A}$ much more dynamic range of complex size was observed in cell culture media however. Polyplex particle size changed in time with a general trend of decreasing diameters. Moderately-agitated transfection complexes (100 rpm, Figure 2.6B) ranged from 1000-500 $\mathrm{nm}$ in diameter, whereas, highly-agitated complexes (200 rpm, Figure 2.6C) had a wider size range of $1300-200 \mathrm{~nm}$. The time scale of the decreasing polyplex size can be characterized by the time the polyplex shrank to $50 \%$ from their original size. This was roughly 10 minutes for the highly-agitated complexes, and over 30 minutes for the moderatelyagitated complexes. The variability of polyplex diameter was low throughout the time course, as the $R^{2}$ to a $3^{\text {rd }}$ degree polynomial best fit line was $>90 \%$, indicating that polyplexes were monodisperse. 
A

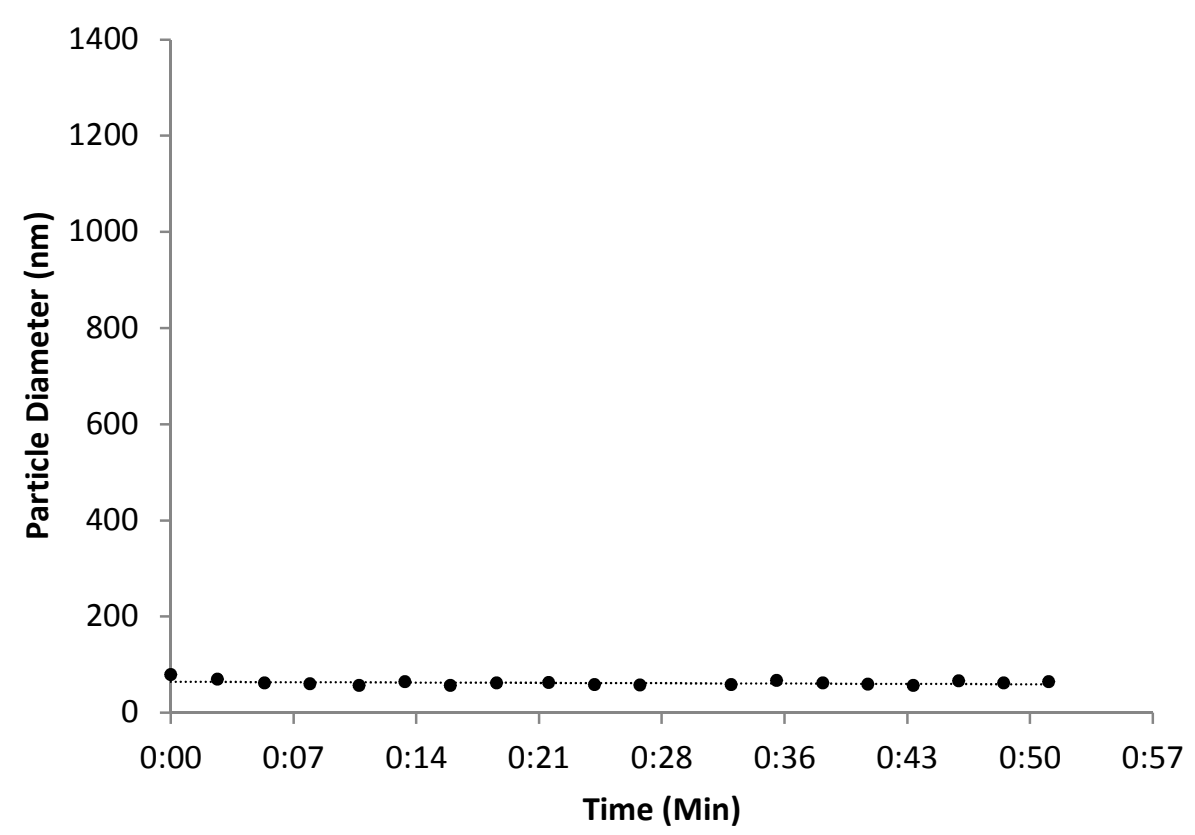

B

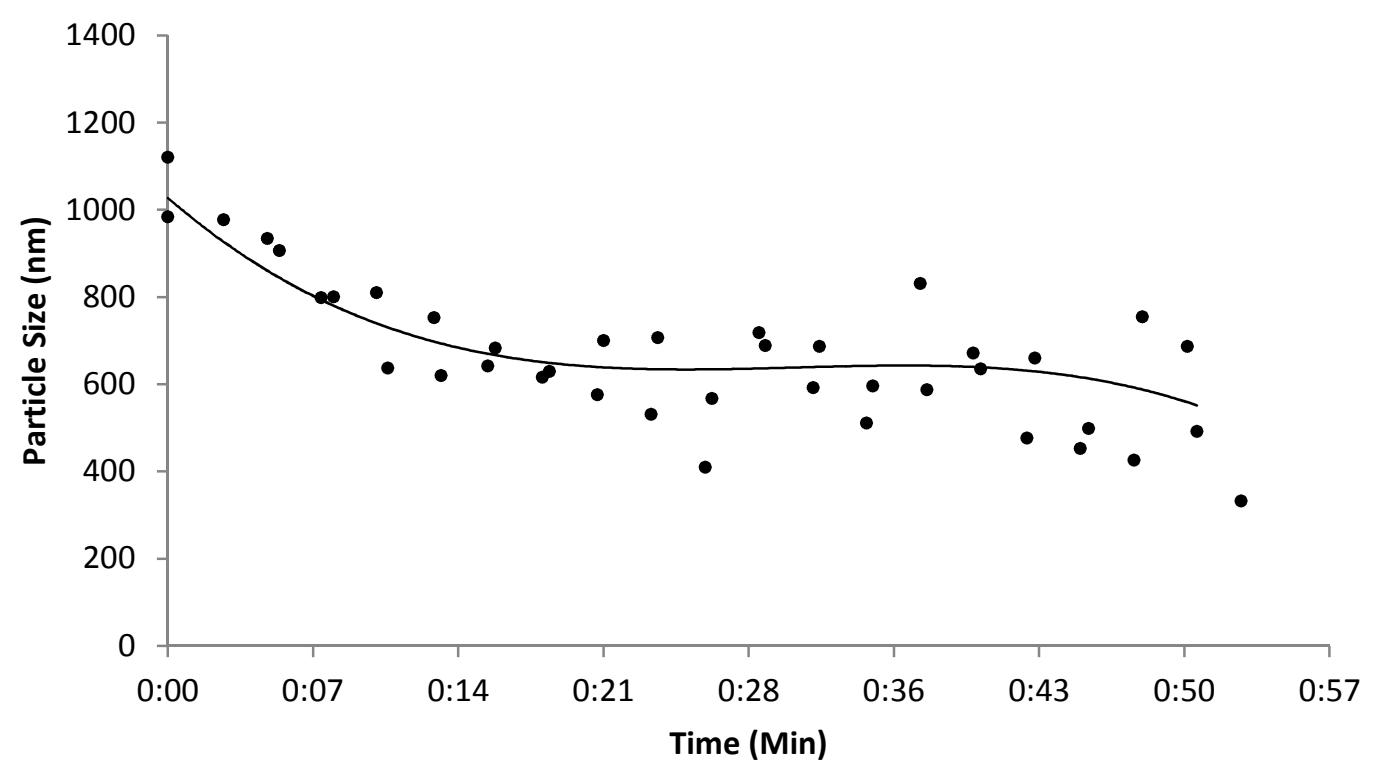




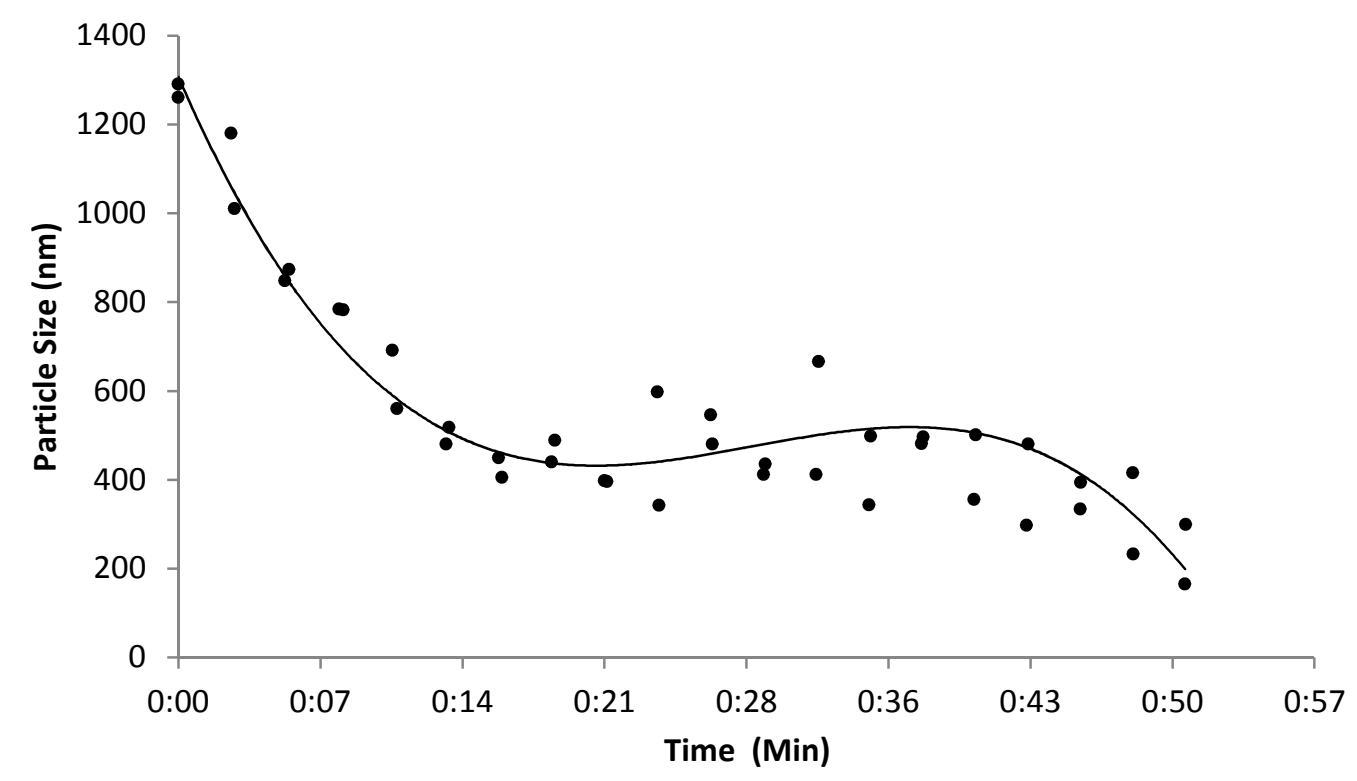

Figure 2.6. Particle size versus time.

Each dot in A-C represents one DLS measurement of $25 \mu \mathrm{g}$ of DNA and $50 \mu \mathrm{g}$ of PEI incubated in $500 \mathrm{ml}$ of solution. Polyplexes were formed in A) High agitation, $200 \mathrm{rpm}$ for 5 minutes in water B) Moderate agitation, 100 rpm for $5 \mathrm{~min}$ in ProCHO media C) or High agitation 200 rpm for $5 \mathrm{~min}$ in ProCHO media

The authors hypothesize that DNA and PEI molecules interact mainly through electrostatic interactions which have competing binding sites with charged species found in culture media. Intracellular proteins have been shown to displace PEI and DNA from polyplexes (lida et al. 2007)..$^{35}$ In a similar fashion, media components likely form transitory bonds with polyplexes. During the incubation process, polyplexes can either form more compact complexes and further condense DNA, or aggregate to form larger multimeric complexes (Tros de Ilarduya et al. 2010). ${ }^{36}$ Aggregation of plasmids and PEI would form heterodisperse complexes. Although a large change in complex size with time was observed, variability at each individual time point was low. The trend of decreasing size of polyplexes indicates that PEI and DNA form more compact complexes in time. Bound media components are likely displaced by intra-polyplex 
interactions. The time scale observed for this phenomenon was dependent on agitation and ranged from 10-30 minutes.

Forming optimal size polyplexes is an important component for a successful transfection. Observations from these experiments indicate mixing and agitation during the polyplex formation step influence polyplex size. Heterogeneities in mixing environment may negatively affect the formation of optimal polyplexes. Therefore, scale-up of TGE could be impacted by the ability to form optimal polyplexes in large bioreactors. However, the use of preformed complexes may alleviate this concern (Schaeger and Christensen 1999; Finsinger et al. 2000; Fukumoto et al. 2010; Raymond et al. 2011; Fliedl and Kaisermayer 2011; Jang et al. 2006).

\subsubsection{Cell density effect on transfection}

In order to experimentally investigate the transfection process, $125-\mathrm{ml}$ shaker flasks were transfected with variable cell densities. Cell density at transfection was tested at $25 * 10^{6}$ cells $/ \mathrm{ml}, 12.5 * 10^{6}$ cells $/ \mathrm{ml}$, and $6.25 * 10^{6}$ cells $/ \mathrm{ml}$. Each culture was transfected under similar conditions with the absolute concentration of PEI $(100 \mu \mathrm{g} / \mathrm{ml})$, and DNA $(50 \mu \mathrm{g} / \mathrm{ml})$ held constant across conditions. Transfection resulted (Figure 2.7, Table 2.3) in a linear decrease in integrated cell viability (IVCD) with a decrease in cell density. IVCD was a result of initial cell concentration, cell maintenance and growth. Transfected cells grew throughout the culture in the $25 * 10^{6}$ cells $/ \mathrm{ml}$ treatment group, for the first three days in the $12.5 * 10^{6}$ cells $/ \mathrm{ml}$ treatment group, and not at all in the $6.25 * 10^{6}$ cells $/ \mathrm{ml}$ treatment group. Viability was similar to growth and had a linear increase with an increase in cell density. These viability and growth 
observations, although limited, were consistent with a cyototoxic effect related to the number of polyplexes per cell.

Titer and $\mathrm{Q}_{\mathrm{p}}$ were however, not linearly related to cell density. Final titer of cultures was similar among the 6.25 and 25 transfection cultures, while there was a significant increase in titer in the 12.5 transfection culture. These three conditions match to the three different sections outlined in Figure $\mathbf{2 . 2}$ and demonstrate the complex window of optimal polyplexes per cell. From the experimental conditions tested, the best ratio was $4 \mu \mathrm{g}$ DNA/ $10^{6}$ cells and $0.5 \mu \mathrm{g}$ DNA/ $\mu$ g PEI.

A

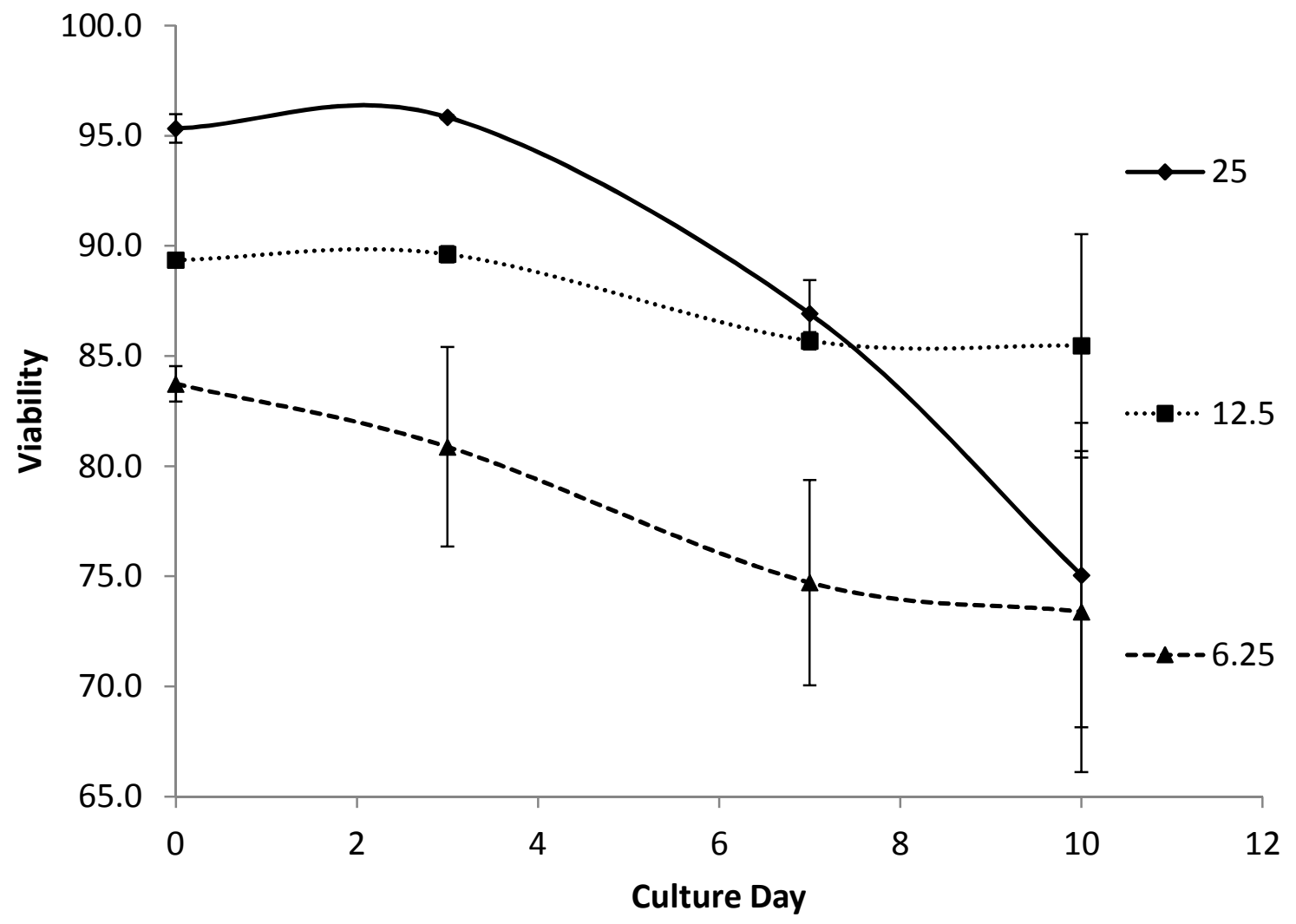


B

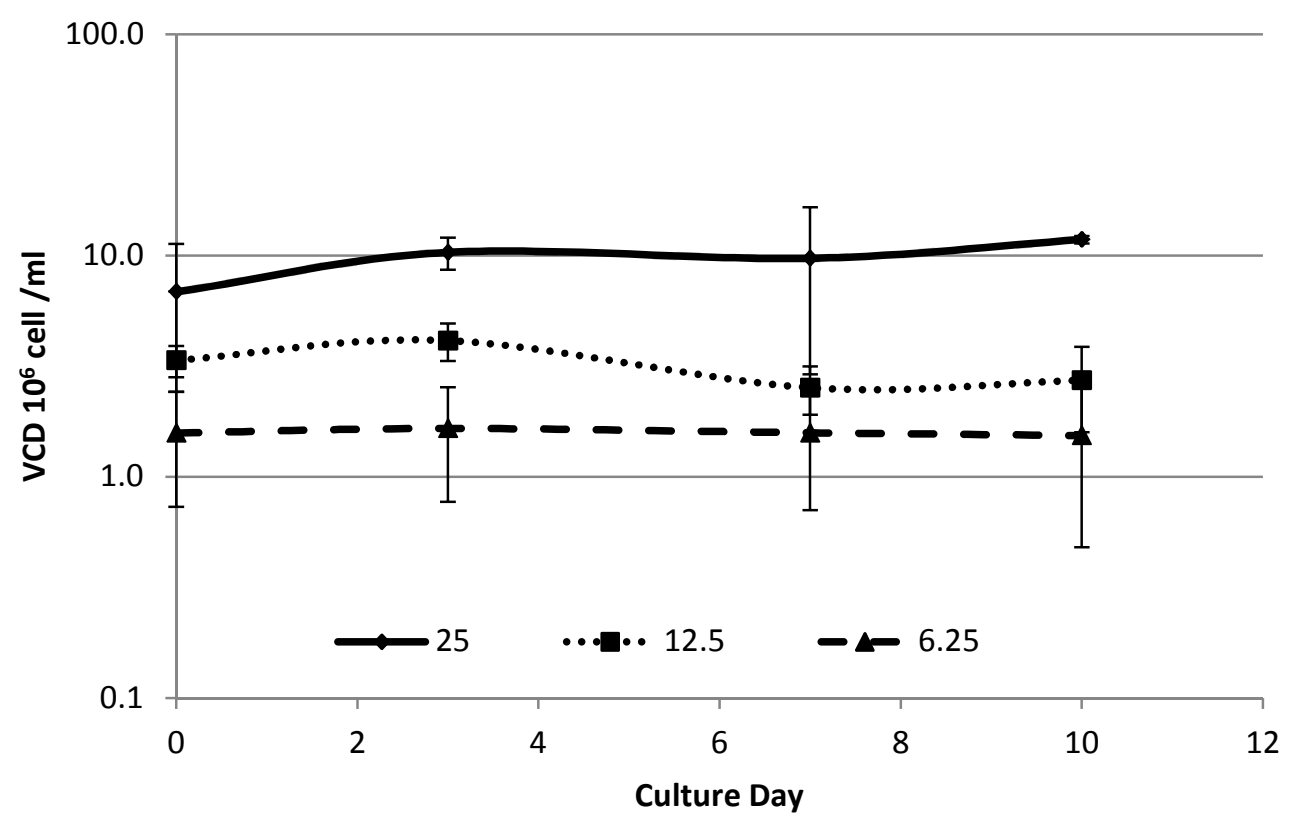

C

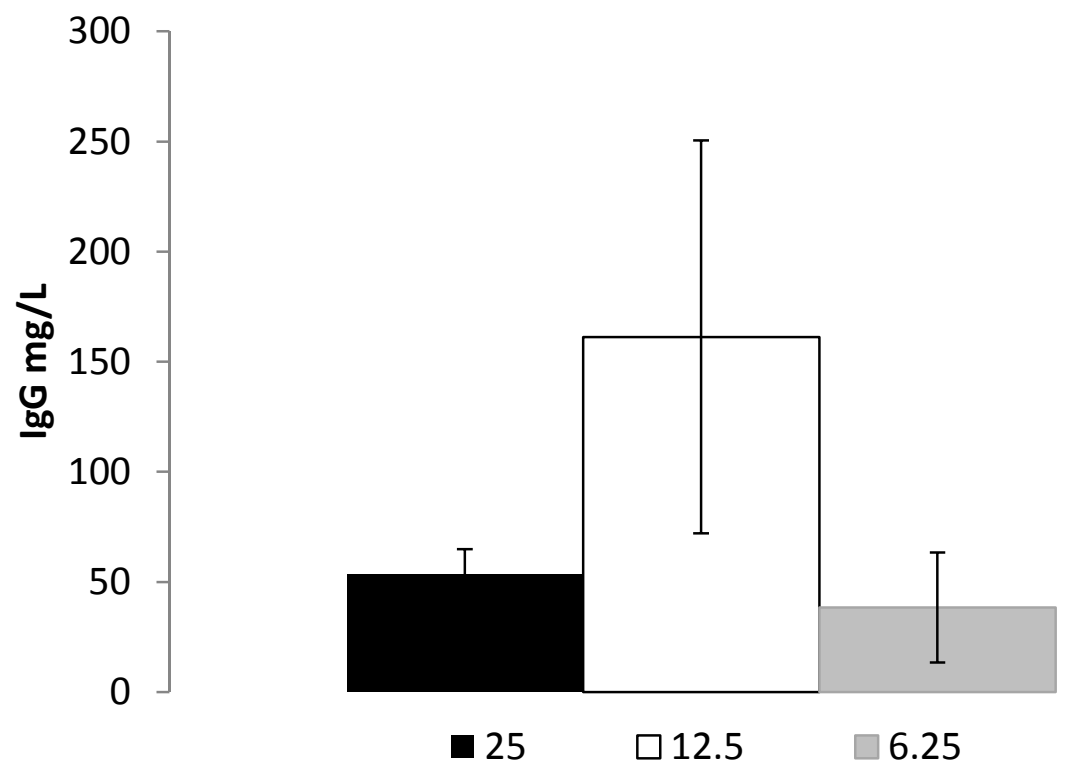

Figure 2.7. Cell density effect on transfection.

Cell mass was diluted into $25,12.5$ and $6.25 * 10^{6}$ cells $/ \mathrm{ml}$ during transfection, then transfected under identical conditions. A) Viability B) Viable cell density and C) Final titer. Error bars represent one standard deviation ( $\mathrm{n}=3)$. 
Table 2.3. Cell density effect on transfection

Culture Condition

\begin{tabular}{|c|c|c|c|}
\cline { 2 - 4 } \multicolumn{1}{c|}{} & $\mathbf{2 5}$ & $\mathbf{1 2 . 5}$ & $\mathbf{6 . 2 5}$ \\
\hline Titer & $53 \pm 11$ & $160 \pm 89$ & $38 \pm 25$ \\
\hline IVCD & $98 \pm 37$ & $32 \pm 7.5$ & $16 \pm 9$ \\
\hline Qp & $0.54 \pm 0.11$ & $4.9 \pm 2.8$ & $2.3 \pm 1.6$ \\
\hline
\end{tabular}

\subsubsection{Agitation}

Figure 2.5 calculated an exponential relationship to mass transport and agitation. A direct agitation study was conducted in shaker flasks in order to investigate the effects of agitation during transfection. 125-ml shaker cultures were transfected using the XLG protocol. Cultures were agitated at various speeds during the three hour transfection incubation period immediately following the addition of PEI and DNA at a temperature of $37^{\circ} \mathrm{C}$. The rotating platform used to agitate the cultures, housed within the same incubator, ranged from 110, 150, 180 and 210 rpms. Three hours after transfection, cultures were moved to a hypothermic incubator $\left(31^{\circ} \mathrm{C}\right)$ and cultivated at $130 \mathrm{rpm}$ for the remainder of the culture ( 8 days). These cultures displayed a positive correlation between agitation and volumetric productivity until the highest agitation condition (Figure 2.8). The viability of the $210 \mathrm{rpm}$ condition after transfection 
was very low, and too few viable cells remained for further investigation (Data not shown). It is important to note, that non-transfected cells cultivated under these conditions do not experience any cytotoxic effects, even at the highest agitation speed. Increases in rpm from 110 to 180 could have increased the amount of DNA/cell into a more optimal range. Further increase in rpm to 210 could have pushed DNA/cell into the cytotoxic range. Alternatively, or in combination, the transfected cells could be sensitive to the hydrodynamic forces at $210 \mathrm{rpm}$. Although limited, these results are consistent with the optimal DNA/cell hypothesis.

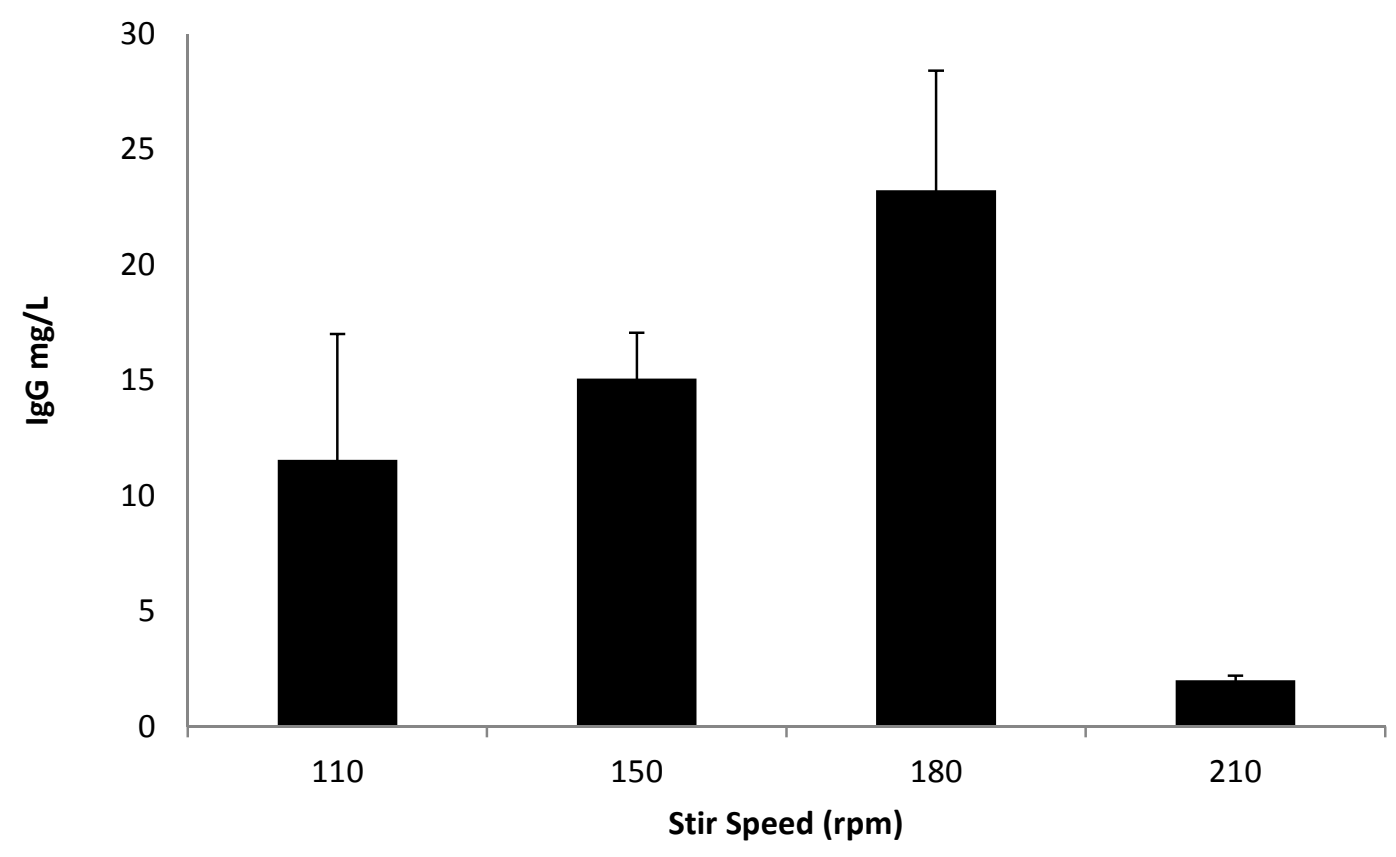

Figure 2.8. Agitation effect on transfection.

CHO culture was centrifuged and resuspended in ProCHO media. DNA and PEI were directly added to cultures using the XLG protocol then incubated at $37^{\circ} \mathrm{C}$ at $110,150,180$ or $210 \mathrm{rpms}$ for three hours on a shaking platform before being housed in a hypothermic incubator. Titer was assayed 8 days after transfection. Error bars represent one standard deviation in analytical measurement $(\mathrm{n}=3)$. 


\subsubsection{Incubation effect on transfection}

In order to understand the effect of transfection incubation time cells were transfected with identical concentration of cells, DNA and PEI but were subject to either 90 or 360 minutes of incubation at a temperature of $37^{\circ} \mathrm{C}$. Cells were then fed a bolus of fresh medium fortified with $3.8 \mathrm{mM}$ valproic acid after transfection and maintained at $31^{\circ} \mathrm{C}$. Increases in incubation time lead to an increase in both cytotoxicity and specific productivity of transfected cells. (Figure 2.9). Cytotoxicity in the 360 minute incubation condition was $25 \%$ higher than in the 90 minute condition, where as specific productivity was only $5 \%$ higher. Longer incubation times increases the amount of polyplex transport to the surface of the cell and thus internalized DNA.

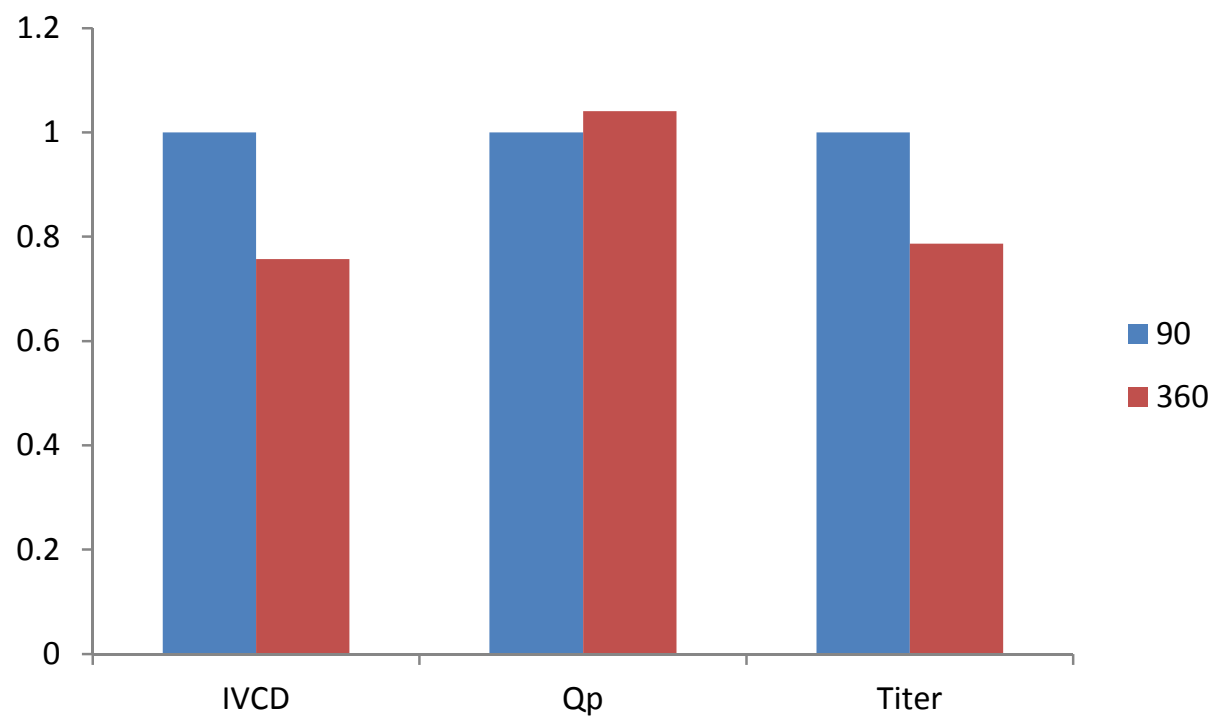

Figure 2.9. Normalized time and temperature effect on transfection.

Cells were transfected with $20 * 10^{6}$ cells $/ \mathrm{ml}, 50 \mu \mathrm{g}$ DNA $/ \mathrm{ml}$ and $100 \mu \mathrm{g}$ PEI $/ \mathrm{ml}$. Transfections were incubated for either 90 minutes or 360 minutes at $37^{\circ} \mathrm{C}$. 


\subsubsection{Polyplex internalization}

Once the polyplex adsorbs to the cell surface, it is internalized through ATP dependent protein complexes. This cellular uptake is a complicated phenomenon that includes a number of distinct internalization pathways (Sahay et al. 2012). Polyplexes formulated with $25 \mathrm{kDa}$ PEI likely rely on a combination of macropinocytosis and clathrin-mediated endocytosis (Kircheis et al. 2001; Hufnagel et al. 2009; Wong et al. 2010; Ulasov et al. 2011). Scale-up may affect polyplex internalization in a number of ways. As the cell's ability to import the polyplex is a function of the particles size, scale-up may affect particle formation. Moreover, endocyosis rates may be impacted by agitation. Polyplexes interact with the plasma membrane through unstable electrostatic interactions. Increases in agitation would lead to larger shear forces. These forces could possibly disrupt these adsportive interactions and impair internalization. The conflicting relationship between increased mass transfer and decreased internalization rate has previously been observed for cationoic lipid based gene transfer (Harris and Giorgio 2005; Fujiwara et al. 2006). In those studies, an applied shear stress increased the mass transfer rate to the surface of the cell, but destabilized the absorptive interactions between cell and lipoplex. Scale-up employing a constant $\varepsilon$ (power/volume) may likely avoid inhibitory effects of increased dissociation of polyplexes from cell surface.

\subsubsection{Intracellular polyplex transport and cellular metabolism}

Intracellular transport of polyplexes is a complicated biological process, and has been associated with the physiological health of the cell (Carpentier et al. 2007). ${ }^{46}$ Of most importance is the state of the cell in the cell cycle, as nuclear import of pDNA is enhanced 
during mitosis (Grosjean et al. 2002; Geisse 2009). ${ }^{7,47}$ Cell metabolism during transfection is difficult to investigate due to the rapid time frame of gene-transfer, thus has not been studied. During this process, however, scale-up of agitation and aeration equipment may impact cell metabolism. One potential problem during scale-up is an increase in maximum shear stress, as the ratio of maximum local to average power dissipation increases in large bioreactors. Mixing regimes employed for large scale bioreactors do not produce shear forces that impair cell function in stable cell culture (Chisti 1993) ${ }^{48}$. Therefore, increased shear stress at larger scales is not likely to negatively impact cultivation of cells. However, as PEI binds to the cell membrane, differences in shear sensitivity between stably transfected cells and transiently transfected cells may be altered. Studies on mechanisms of death in PEI mediated gene transfer indicate mainly the intrinsic apoptotic pathway (mitochondrial signaling) as the mechanism of post-transfection cell death (Beyerle et al. 2010). ${ }^{49}$ Shear forces in cell culture often induce cell death through other pathways (Al-Rubeai and Singh 2003) ${ }^{50}$. Protein production machinery, have been shown to be altered with increasing levels of shear (Frangos et al. 1988; Senger and Karim 2003). ${ }^{51,52}$ Investigations into the shear sensitivity of transiently transfected cells are warranted.

Many of the findings in the present study were not able to be explained solely through mass transport. They may have been impacted by factors not included in this analysis, such as intracellular trafficking rate, DNA replication rates, cell cycle transition rates, lysosomal activity rates and endocyotic machinery activities. Altered metabolism has been observed with changes in temperature, especially a delayed onset of apoptosis and a reduced growth rate (Moore et al. 1997; Rode et al. 1997; Ducommun et al. 2002). ${ }^{53-55}$ Scale-up may affect transfected-cell 
metabolism, although the ability for large-scale bioreactors to successfully accommodate the demands of high-cell density, stable cultures suggest that it will not be a limiting factor.

\subsection{Future Work}

Ultimately, this work has predicted the possibility of achieving large scale transfections. In order to scale transfection, transport of polyplexes from the medium to the cell should be taken into consideration. This includes an optimum number of plasmids entering into each cell, which is a function of cell concentration, cell/PEI/DNA ratio and agitation. Additional work may entail investigation into transfection with incubation times less than 90 minutes, which may demonstrate mass transport limitations in shaker flasks. In addition, pilot scale studies should be conducted to investigate the validity of these findings and generate protocols for rapid production of very large quantities of recombinant protein.

\subsection{References}

Al-Rubeai M, Singh RP (1998) Apoptosis in cell culture. Current Opin Biotechnol 9 (2):152-156

Arscott PG, Li A, Bloomfield VA. Condensation of DNA by trivalent cations. 1. Effects of DNA length and topology on the size and shape of condensed particles. Biopolymers 1990; 30: 619630.

Ausubel FM, Brent R, Kingston RE, Moore DD, Seidman JG, Smith JA et al (2002) Current protocols in molecular biology. John Wiley \& Sons, New Jersey

Backliwal G, Hildinger M, Chenuet S, Wulhfard S, De Jesus M, Wurm FM (2008) Rational vector design and multi-pathway modulation of HEK 293E cells yield recombinant antibody titers exceeding $1 \mathrm{~g} / \mathrm{l}$ by transient transfection under serum-free conditions. Nucleic Acids Res 36:e96 
Baldi L, Muller N, Picasso S, Jacquet R, Girard P, Thanh HP, Derow E, Wurm FM (2005) Transient gene expression in suspension HEK-293 cells: application to large-scale protein production. Biotechnol Prog 21:148-153

Baldi L, Hacker DL, Adam M, Wurm FM (2007) Recombinant protein production by large-scale transient gene expression in mammalian cells: state of the art and future perspectives. Biotechnol Lett 29:677-684

Barrett TA, Wu A, Zhang H, Levy MS, Lye GJ, (2010) Microwell engineering characterization for mammalian cell culture process development. Biotechnol. Bioeng. 105: 260-275

Bertschinger M, Backliwal G, Schertenleib A, Jordan M, Hacker DL, Wurm FM (2006) Disassembly of polyethylenimine- DNA particles in vitro: implications for polyethylenimine mediated DNA delivery. J Control Release 116:96-104

Beyerle A, Irmler M, Beckers J, Kissel T, Stoeger T (2010) Toxicity pathway focused gene expression profiling of PEI-based polymers for pulmonary applications. Mol Pharm 7(3):727-37

Blessing T, Kursa M, Holzhauser R, Kircheis R, Wagner $E(2001)$ Different strategies for formation of pegylated EGF-conjugated PEI/DNA complexes for targeted gene delivery. Bioconjug. Chem. 12:529-537

Boussif O, Lezoualch F, Zanta MA, Mergny MD, Scherman D, Demeneix B, Behr JP (1995) A versatile vector for gene and oligonucleotide transfer into cells in culture and in vivo: polyethylenimine. Proc Natl Acad Sci USA 92: 7297-7301

Brunner S, Sauer T, Carotta S, Cotten M, Saltik M, Wagner E (2000) Cell cycle dependence of gene transfer by lipoplex polyplex and recombinant adenovirus.GeneTher 7:401-407

Brus C, Petersen H, AignerA , Czubayko F, Kissel T (2004) Efficiency of polyethylenimines and polyethyleniminegraft-poly (ethylene glycol) block copolymers to protect oligonucleotides against enzymatic degradation. Eur. J. Pharm. Biopharm. 57 :427-430

Capecchi MR (1980) High efficiency transformation by direct microinjection of DNA into cultured mammalian cells. Cell 22:479-488

Carpentier E, Paris S, Kamen AA, Durocher $Y$ (2007) Limiting factors governing protein expression following polyethylenimine-mediated gene transfer in HEK293-EBNA1 cells. J Biotechnol 128:268-280

Chan P, Kurisawa M, Chung JE, Yang YY (2007) Synthesis and characterization of chitosan-gpoly(ethylene glycol)-folate as a non-viral carrier for tumor-targeted gene delivery, Biomaterials 28:540-549 
Chillakuru R, Ryu D, Yilma T. 1991. Propagation of recombinant vaccinia virus in HeLa cells: Adsorption kinetics and replication in batch cultures. Biotechnol Prog 7:85-92.

Chisti Y (1993) Animal cell culture in stirred bioreactors: Observations on scale-up. Bioprocess Engineering 9:191-196

Cebrián V, Martín-Saavedra F, Yagüe C, Arrubebo M, Santamaría J, Vilaboa N (2011) Sizedependent transfection efficiency of PEI_coated gold nanoparticles. Acta Biomaterialia 7:36453655

Chu YW, Wang R, Schmid I, Sakamoto KM (1999) Analysis with flow cytometry of green fluorescent protein expression in leukemic cells. Cytometry 36:333-339

Chuck As, Clarke MF, Palsson BO (1996) Retroviral infection is limited by Brownian motion. Hum Gene Ther 7:1527-1534

Chuck AS, Palsson BO (1996) Consistent and high rates of gene transfer can be obtained using flow-through transduction over a wide range of retroviral titers. Hum Gene Ther 7(6):743-750.

Clamme JP, Azoulay J, Mély Y (2003) Monitoring of the formation and dissociation of polyehtylenimine/DNA complexes by two photon fluorescence correlation spectroscopy. Biophysical J 84:1960-1968

Derouazi M, Girard P, Van Tilborgh F, Iglesias K, Muller N,Bertschinger M, Wurm FM (2004) Serum-free large-scale transient transfection of $\mathrm{CHO}$ cells. Biotechnol Bioeng 87:537-545

Doran PM (1995) Bioprocess engineering principles. $7^{\text {th }}$ Edi, Elsevier Ltd, Oxford, UK

Ducommun P, Rueux PA, Kadouri A, von Stockar U, Marison IW (2002) Monitoring of temperature effects on animcal cell metabolism in a packed bed process. Biotechnol Bioeng 77 (7):838- 842

Dunlap DD, Maggi A, Soria MR, Monaco L (1997) Nanoscopic structure of DNA condensed for gene delivery. Nucleic Acids Res 25:3095-3101

Dusting J, Sheridan J, Hourigan K (2006) A fluid dynamics approach to bioreactor design for cell and tissue culture. Biotechnol Bioeng 94 (6) 1196-1208

English TJ, Hammer DA. 2004. Brownian adhesive dynamics (BRAD) for simulating the receptormediated binding of viruses. Biophys J 86: 3359-3372

English TJ, Hammer DA. 2005. The effect of cellular receptor diffusion on receptor-mediated viral binding using Brownian adhesive dynamics (BRAD) simulations. Biophys J 88:1666-1675 
Erbacher P, Zou S, Bettinger T, Remy JS (1998) Chitosan-based vector/ DNA complexes for gene delivery: biophysical characteristics and transfection ability. Pharm Res 15: 1332-1339.

Finsinger, D, Remy JS, Erbacher P, Koch C, Plank C, (2000) Protective copolymers for nonviral gene vectors: synthesis, vector characterization and application in gene delivery. Gene Ther. 7:1183-1192

Forbes DJ (1992) Structure and function of the nuclear-pore complex. Annu Rev Cell Biol 8:495527

Fliedl L, Kaisermaye C (2011) Transient gene expression in HEK293 and vero cells immobilised on microcarriers. J Biotechnol 153 (2) 15-21

Frangos JA, Mclntire LV, Eskin SG (1988) Shear stress induced stimulation of mammalian cell metabolism. Biotechnol Bioeng 32 (8): 1053-1060

Fukumoto Y, Obata Y, Ishibashi K, Tamura N, Kikuchi I, Aoyama K, Hattori Y, Tsuda K, Nakayama, $\mathrm{Y}$, Yamaguchi N (2010) Cost-effective gene transfection by DNA compaction at pH 4.0 using acidified, long shelf-life polyethylenimine. Cyotechnol 62 (1) 73-82

Furtbauer E, Sauer T, Kursa M, Wagner E (2002) Overcoming the nuclear barrier: cell cycle independent nonviral gene transfer with linear polyethylenimine or electroporation. Mol Ther 5:80-86

Gao X, Yao L, Song Q, Zhu L, Xia Z, Xia H, Jiang X, Chen J, Chen H (2011) The association of autophagy with polyethylenimine-induced cytotoxicity in nephritic and hepatic cell lines. Biomaterials 32(33):8613-25

Garcia-Ochoa F, Gomex E (2009) Scale-up and oxygen transfer rate in microbial processes: an overview. Biotechnol Adv 27:153-176

Garcia-Ramirez M, Subirana JA. Condensation of DNA by basic proteins does not depend on protein composition. Biopolymers 1990; 34: 285-292

Geisse S. and Fux C. Recombinant protein production by transient gene transfer into mammalian cells. Chapter 15 in Methods in Enzymology 2009, (463) 223-38

Geisse S (2009) Reflections on more than 10 years of TGE approaches. Protein Expression and Purification 64:99-107.

Gilbert PA, Kamen A, Bernier A, Garnier A (2007) A simple macroscopic model for the diffusion and adsorption kinetics of r-Adenovirus. Biotechnol Bioeng. 98:239-251 
Girard P, Porte L, Berta T, Jordan M, Wurm FM (2001) Calcium phosphate transfection optimization for serum-free suspension culture. Cytotechnology 35:175-180

Girard P, Derouazi M, Baumgartner G, Bourgeois M, Jordan M, Jacko B, Wurm FM (2002) 100liter transient transfection. Cytotechnology 38:15-21

Godbey WT, Wu KK, Mikos AG (1999) Tracking the intracellular path of poly(ethylenimine)/DNA complexes for gene delivery. Proc Natl Acad Sci USA 96:5177-5181

Gottschalk S, Cristiano RJ, Smith LC, Woo SL. Folate receptor mediated DNA delivery into tumor cells: potosomal disruption results in enhanced gene expression. Gene Therapy 1994; 1: 185191

Goula D, Remy JS, Erbacher P, Wasowicz M, Levi G, Abdallah B, Demeneix BA (1998) Size, diffusibility and transfection performance of linear PEI/DNA complexes in the mouse central nervous System. Gene Ther. 5:712-717

Grosjean F, Batard P, Jordan M, Wurm FM (2002) S-phase synchronized CHO cells show elevated transfection efficiency and expression using CaPi. Cytotechnology 38:57-62

Grosse S, Thevenot G, Monsigny M, Fajac I (2006) Which mechanism for nuclear import of plasmid DNA complexed with polyethylenimine derivatives? J Gene Med 8:845-851

Han X, Sun L, Fang Q, Li D, Gong X, Wu Y, Yang S, Shen BQ (2007) Transient expression of osteopontin in HEK 293 cells in serum-free culture. Enzyme Microb Technol 41: 133-140

Han X, Fang Q, Yao F, Wang X, Wang J, Yang S, Shen BQ (2009) The heterogeneous nature of polyethylenimine-DNA complex formation affects transient gene expression. Cytotechnology 60:63-75

Harris SS, Giorgio TD (2005) Convective flow increases lipoplex delivery rate to in vitro cellular monolayers. Gene Ther 12:512-520

Hlavacek WS, Wofsy C, Perelson AS. 1999. Dissociation of HIV-1 from follicular dendritic cells during HAART: Mathematical analysis. Proc Natl Acad Sci USA 96:14681-14686.

Hufnagel H, Hakim P, Lima A, Hollfelder F (2009) Fluid phase endocytosis contributes to transfection of DNA by PEI-25. Molecular Therapy 17 (8) 1411-1417

lida T, Mori T, Katayam Y, Niidome T (2007) Overall interaction of cytosolic proteins with the PEI/DNA complex. J Controlled Release 118:364-369

James MB, Giorgio TD (2000) Nuclear-associated plasmid, but not cell-associated plasmid, is correlated with transgene expression in cultured mammalian cells. Mol Ther 1 (4):339-346 
Jang J, Bengali Z, Houchin TL, Shea LD (2006) Surface adsorption of DNA to tissue engineering scaffolds for efficient gene delivery. J Biomed Mater Res A. 77 (1): 50-58

Kaiser SC, Löffelholz C, Werner S, Eibl D (2011) CFD for Characterizing Standard and single-use stirred cell culture bioreactors: Computational fluid dynamics technologies and applications, Ed Minin IV, Minin OV. InTech

Kircheis R, Wightman L, Wagner E (2001) Design and gene delivery activity of modified polyethylenimines. Adv Drug Del Rev 53:341-358

Kichler A, Leborgne C, Coeytaux E, Danos O (2001) Polyehtylenimine-mediated gene delievery: a mechaninsitic study. J Gene Med. 3:135-144

Kopatz I, Remy JS, Behr JP (2004) A model for non-viral gene delivery: through syndecan adhesion molecules andpowered by actin. J Gene Med 6:769-776

Kunath K, von Harpe A, Fischer D, Peterson H, Bickel U, VoigtK, Kissel T (2003) Low-molecularweight polyethylenimine as a non-viral vector forDNAdelivery: comparison of physicochemical properties, transfection efficiency and in vivo distribution with high-molecular-weight polyethylenimine. J Control Release 89:113-125

Lara AR, Galindo E, Ramirez, Palomares LA (2006) Living with heterogeneities in bioreactors. Mol Bio 34:355-381

Löfås S, Johnsson B (1990) A novel hydrogel matrix on gold surfaces in surface plasmon resonance sensors for fast and efficient covalent immobilization of ligands. J Chem Commun 21:1526-1528

Lungwitz U, Breunig M, Blunk T, Gopferich A (2005) Polyethylenimine- based non-viral gene delivery systems. Eur J Pharm Biopharm 60:247-266

Mannisto M, Ronkko S, Matto M, Honkakoski P, Hyttinen M, Pelkonen J, Urtti A (2005) The role of cell cycle on polyplex- mediated gene transfer into a retinal pigment epithelial cell line. J Gene Med 7:466-476

Moore A, Mercer J, Dutina G, Donahue CJ, Bauer KD, Mather JP, Etcheverry T, Ryll T (1997) Effects of temperature shift on cell cycle, apoptosis and nucleotide pools in $\mathrm{CHO}$ cell batch cultures. Cytotechnology 23:47-54

Nie H, Lee L, Tong H, Wang C (2008) PLGA/chitosan composites from a combination of spray drying and supercritical fluid foaming techniques: new carriers for DNA delivery. J. Control. Release 129:207-214 
Nyberg-Hoffman C, Shabram P, Li W, Giroux D, Aguilar-Cordova E. 1997. Sensitivity and reproducibility in adenoviral infectious titer determination. Nat Med 3:808-811.

Ogris M, Steinlein P, Kursa M, Mechtler K, Kircheis R, Wagner E (1998) The size of DNA/transferrin-PEI complexes is an important factor for gene expression in cultured cells. Gene Ther. 5:1425-1433

Palumbo R. N.; Zhong X.; Wang C. Polymer-mediated DNA vaccine delivery via bystander cells requires a proper balance between transfection efficiency and cytotoxicity. J. Controlled Release 2012, (157) 86-93

Plum GE, Arscott PG, Bloomfield VA. Condensation of DNA by trivalent cations. 2 Effects of cation structure. Biopolymers 1990; 30: 631-643.

Prokop A, Rosenberg MZ (1989) Bioreactor for Mammalian Cell Culture. Advances in Biochemical Engineering. Biotechnology, Edi: A. Fiechter, Sprirlger-Verlag, Berlin, Heidelberg,39: 30-67

Rajendra Y.; Kiseljak D.; Baldi L.; Hacker D. L.; Wurm F. M. A simple high-yielding process for transient gene expression in CHO cells. J. Biotechnol. 2011 (153) 22-6

Rode M, Ber T, Gjøen T (1997) Effect of temperature on endocytosis and intracellular transport in the cell line SHK-1 derived from salmon head kidney. Biochem Physiol 117A (4):531-537

Sahay G, Alakhova DY, Kabanov AV (2010) Endocytosis of naomedicines. J Controlled Release 145:182-195

Salman H, Zbaida D, Rabin Y, Chatenay D, Elbaum M (2001) Kinetics and mechanism of DNA uptake into the cell nucleus. Proc Natl Acad Sci USA 98 (13) 7247-7252

Schlaeger EJ, Christensen K (1999) Transient gene expression in mammalian cells grown in serum-free suspension culture. Cytotechnology 30:71-83

Senger RS, Karim MN (2003) Effect of shear stress on intrinsic CHO culture state and glycosylation of recombinant tissue-type plasminogen activator protein. Biotechnol Prog. 4:1199-1209

Stettler M, Zhang X, Hacker DL, Jesus MD, Wurm FM (2007) Novel orbital shake bioreactors for transient production of CHO derived IgGs. Biotechnol Prog 23: 1340-1346.

Smith K, Sharp D. 1960. Interaction of virus with cells in tissue cultures I: Adsorption on and growth of vaccinia virus in L cells. Virology 11:519- 532. 
Sun X, Goh PE, Wong KT, Mori T, Yap MG (2006) Enhancement of transient gene expression by fed-batch culture of HEK 293 EBNA1 cells in suspension. Biotechnol Lett 28: 843-848

Sun X, Hia HC, Goh PE, Yap MG (2008) High density transient gene expression in suspensionadapted 293 EBNA1 cells. Biotechnol Bioeng 99:108-116

Tang MX, Szoka FC (1997) The influence of polymer structure on the interactions of cationic polymers with DNA and morphology of the resulting complexes. Gene Ther. 4: 823-832

Tayi VS, Bowen BD, Piret JM (2010) Mathematical model of the rate-limiting steps for retrovirus-mediated gene transfer into mammalian cells. Biotechnol. Bioeng. 105: 195-209

Tissot S, Farhat M, Hacker DL, Anderlei T, Kühner M, Comninellis C, Wurm F (2010) Determination of a scale-factor from mixing time studies in orbitally shaken bioreactors. Biochem Eng 52:181-186

Ulasov AV, Khramtsov YV, Trusov GA, Rosenkranz AA, Sverdlov ED, Sobolev AS (2011) Properties of PEI_based polyplex nanoparticles that correlate with their transfection efficiency. Mol Ther 19 (1):103-112

Valentine R, Allison A. 1959. I. Theory of adsorption and experiments on the attachment of particles to non-biological surfaces. Biochimica Biophysica Acta 34:10-23

Varga C, Wickham T, Lauffenburger D. 2000. Receptor-mediated targeting of gene delivery vectors: Insights from molecular mechanisms for improved vehicle design [In Process Citation]. Biotechnol Bioeng 70:593-605.

Varga CM, Tedford NC, Thomas M, Klibanov AM, Griffith LG, Lauffenburger DA (2005) Quantitative comparison of polyethylenimine formulations and adenoviral vectors in terms of intracellular gene delivery processes. Gen Ther 12:1023-1032

Wagner E, Cotten M, Foisner R, Birnstiel ML (1991) Transferrin-poly- cation DNA complexes: the effect of polycations on the structure of the complex and DNA delivery to cells. Proc Natl Acad Sci USA 88: 4255-4259

Wickham T, Granados R, Wood H, Hammer D, Shuler M. 1990. General analysis of receptormediated viral attachment to cell surfaces. Biophys J 58:1501-1516.

Wolfert MA, Schacht EH, Toncheva V, Ulbrich K, Nazarova O, Seymour LW (1996) Characterization of vectors for gene therapy formed by self-assembly of DNA with synthetic block co-polymers. Hum Gene Ther 7: 2123-2133

Wong AW, Baginski TK, Reilly DE (2010) Enhancement of DNA Uptake in FUT8-Deleted CHO Cells for Transient Production of Afucosylated Antibodies. Biotechnol. Bioeng. 106: 751-763 
Xing Z, Kenty BM, Li ZJ, Lee SS (2009) Scale-up analysis for a CHO cell culture process in large scale bioreactors. Biotechnol Bioeng 103:733-746

Ye J.; Kober V.; Tellers M.; Naji Z.; Salmon P.; Markusen J. F.. 2008. High-Level Protein Expression in Scalable CHO Transient Transfection. Biotechnol. Bioeng. 2009 (103) 542-51

Zhang H, Wang W, Quan C, Fan S (2010) Engineering considerations for process development in mammalian cell cultivation. Curr Pharma Biotechnol 11:103-112. 


\title{
CHAPTER 3. OPTIMAL TRANSIENT GENE EXPRESSION SYSTEMS FOR LARGE-SCALE PRODUCTION OF ANTIBODIES
}

\author{
Abstract \\ Transient gene expression in mammalian culture is a potential solution for rapid production of \\ recombinant proteins. The polycation polyethylenimine is a widely used reagent for milligram \\ to gram scale transfections as it is simple to use, cost effective, and provides relatively high \\ titers. As with most transfection reagents, PEI-mediated transfection involves the formation of \\ nanoparticles (polyplexes) which are obtained by its mixing with plasmid DNA. As the quality of \\ polyplexes, physiological condition of the cells, and cultivation method directly impact \\ transfection efficiency and productivity, formation of scalable processes is difficult. This study \\ sought to understand some of the factors in TGE processes that give rise to process variability \\ and generate an optimized TGE protocol. The final method included the use of CHO-S cells in \\ ProCHO5 media using an all-8 antibody. In addition, this process was implemented into a \\ scalable system using tangential flow filtration (TFF) for cell concentration and medium \\ exchange. This allowed transfection to occur in the same bioreactor as inoculum expansion. \\ Moreover, TFF bioreactors provided the highest titer reported in CHO-TGE cultures.
}

\subsection{Introduction}

The introduction of foreign genetic material into cultured eukaryotic cells without selection for stable integration of plasmids into the host genome has become a standard experimental procedure known as transient gene expression (TGE). For decades, transfections 
have been performed in cell biology labs on a small scale basis to analyze the effect of gene/protein perturbation and their effects on biological systems (Geisse 2009). TGE has allowed the production of small amounts of recombinant protein, often in crude supernatants and without sophisticated purification. This approach offers many advantages for researchers as it is rapid, simple and can be applied to a multitude of cell lines (Geisse and Fux 2009).

The first TGE approaches predominantly employed Human Embryonic Kidney-293 (HEK293) cells as the host cell line. More recently, large scale transient transfection protocols have also been established for Chinese Hamster Ovary (CHO) cells (Baldi et al. 2005; Jordan et al. 1998; Pham et al. 2003; Shi et al. 2005; Baldi et al. 2007). Due to their human like posttranslational modifications, $\mathrm{CHO}$ cells are the most commonly used expression host for biopharmaceutical production (Wurm 2004). Transient based CHO processes provide milligram to gram quantities of recombinant protein within weeks. This is in contrast to conventional approaches of generating stable cell lines that takes several months to develop (Wurm and Bernard 1999; Pham et al. 2006)

Polyethlenimine (PEI) is a cationic polymer used in gene transfer for a number of years (Boussif et al. 1995). PEl is available in various configurations, however, $25 \mathrm{kDa}$ linear PEI has been shown to be the best molecular weight and structure for TGE found to date (Bertschinger et al. 2008; Kopatz et al. 2004; Godbey et al. 1999). With a high cationic charge density, PEI condenses DNA to form a compact, positively-charged particle. This complex is endocytosed, and escapes endosomal vesicles through the proton-sponge effect. Basic nitrogen atoms become protonated and cause an influx of chloride ions which rupture the vesicle through osmotic swelling (Akinc et al. 2005; Thomas and Klibanov 2003). Plasmid DNA then travels to 
the nucleus where it is transcribed. How nuclear translocation of polyplexes occurs is not well characterized. As reported for other transfection agents, transnucleation is believed to be one of the major obstacles to high transfection efficiency (Carpentier et al. 2007; Bieber et al. 2002; Brunner et al. 2002; Escriou et al. 2001).

While transfection protocols have yet to be standardized, many studies have looked at increasing the effectiveness of transfection through increasing the number of cells expressing the gene (transfection efficiency) as well as the cell's specific productivity. Many factors involved in the transfection process have been studied, including cell/DNA/PEI ratios, yet there still remain significant gaps in the process understanding and optimization of transfection methods. One goal of this work was to identify an optimal system for r-protein production using off the shelf reagents.

In addition to a high titer, the TGE process developed in this work required scalability. The ability to scale is vital for processes to reduce the cost of manufacture and increase production through scales of economy. For $r$ - protein production by TGE, scales up to hundreds of liters have been successfully employed at commercial firms to produce research material. Most methods employed at these larger scales utilize low cell density cultures with no cell concentration or medium exchange employed as part of the transfection step. These processes do not require sterile cell-liquid separation, yet suffer from low titers. High titer processes, however, utilize high density cultures with cell concentration and medium exchange steps prior to transfection. All such protocols published to date, utilize external batch centrifugation, using lab-scale centrifuges, for media exchange and cell concentration (Wulhfard et al. 2008; Pham et al. 2006; Girard et al. 2002; Tuvesson et al. 2008). This method is typically limited in scale to 20 
liters or less, as cells are typically processed in batches of 6-L or less (i.e, $6 \times 1$-L bottles). There are a number of mammalian cell retention techniques for large scale cultures which have yet to be tested for transfection processes, including gravity settlers, tangential flow filters, acoustic filters, and hydrocyclones (Scheirer, 1988; Tokashiki and Takamatsu, 1993; Woodside et al., 1998; Castilho and Medronho, 2002). The goal of this work was to create an optimal TGE process that can demonstrate scalability to larger bioreactors.

\subsection{Materials and methods}

\subsubsection{Plasmid constructs}

Two plasmids were used in this study. The first, referred to here after as all-8, was p6G4V11N35E.choSD.10 (ATCC HB-11722), designed to coexpress variable light and heavy regions of the murine 6G4.2.5 monoclonal antibody with human constant regions. The second, referred to hereafter as PSEAP-Fc, was pFUSE-SEAP-hIgG1-Fc (InVivogen, Carlsbad, CA) which encodes for a secreted alkaline phosphatase moiety fused to a human IgG1-Fc backbone. Plasmids were either purchased (Nature Technology Corporation, Lincoln NA) or produced in Escherichia coli strain DH5a grown in Luria broth medium containing appropriate antibiotic. Plasmid DNA was isolated and purified using Giga-Prep kit (Qiagen) according to the manufacturer's protocol.

\subsubsection{Cell culture}

Experiments were performed with three different CHO cell lines. (1) CHO-K1 (ATCC: CCL-61), a parental CHO line (Puck et al. 1958); (2) DG44 ( Life Technologies, Hercules, CA), a dhfr- CHO line (Urlaub and Chasin 1980) that is pre-adapted to suspension culture and is frequently used in industry for stable gene expression (SGE) and (3) CHO-S (Life Technologies), a CHO line 
derived from $\mathrm{CHO}-\mathrm{K} 1$ that is pre-adapted to chemically defined, suspension culture (Deaven \& Petersen 1973; D'Anna 1996; D'Anna et al. 1997). CHO-K1 cells were cultured for at least one passage adhered to a T-flask (Corning). The cells were removed from the flask surface through trypsinization, placed in suspension culture in a shaker flask and subsequently grown in suspension culture. All cells were initially grown in DG44 media (Life Technologies), then cultured in either chemically defined ProCHO5 media (Lonza) supplemented with $4.1 \mathrm{mM}$ Lglutamine, HT supplement (Life Technologies) or OptiCHO media (Life Technologies) supplemented with 8mM L-glutamine. Cells were passaged every 3-4 days at densities ranging from $0.3 * 10^{6}$ cells $/ \mathrm{ml}$ to $5.0 * 10^{6}$ cells $/ \mathrm{ml}$ (more dense passaging was used for scale-up). Cells were cultivated in $125 \mathrm{ml}$ shaker flasks (Corning) operated at $30 \mathrm{mls}$ of culture volume, placed in a large, humidified incubator (Thermofisher) at $37^{\circ} \mathrm{C}, 8 \% \mathrm{CO}_{2}$. The shaker cultures were agitated on a rotary shaker (New Brunswick) at $130 \mathrm{rpm}$.

\subsubsection{Transfections in shaker flasks}

Transfections were a modified version of the XLG protocol (Backliwal et al. 2009). Cells were centrifuged prior to transfection and resuspended at a cell density of $20 * 10^{6}$ cells $/ \mathrm{ml}$ in ProCHO5 media. DNA was added to a final concentration of $50 \mu \mathrm{g} / \mathrm{ml}$ directly to the cells. This was immediately followed by addition of the appropriate amount of a $1 \mathrm{mg} / \mathrm{ml}$ solution of 25 kDa polyethyleneimine (PEl; Polysciences) to a final concentration of $100 \mu \mathrm{g} / \mathrm{ml}$. Four hours after transfection, cells were diluted with media to a cell density of $4 * 10^{6}$ cells $/ \mathrm{ml}$, and valproic acid (VPA, Sigma-Aldrich) was added to a final concentration of $3.8 \mathrm{mmol} / \mathrm{l}$. Cultures were performed in triplicate and maintained with agitation at $31^{\circ} \mathrm{C}$ for up to 10 days with $30 \mathrm{ml}$ final volume after dilution in a $125 \mathrm{ml}$ shaker flask (Corning). 


\subsubsection{Transfection in bioreactors}

Bioreactor transfections used the same Cell/DNA/PEI ratio as small scale. Cells were grown in either 1- or 3-L bioreactors (Applikon, Foster City, CA) in ProCHO5 media. Cells were maintained below $5 * 10^{6}$ cells $/ \mathrm{ml}$ in order to ensure exponential growth. Cultures were maintained at set points $37^{\circ} \mathrm{C}, 200 \mathrm{rpm}, \mathrm{pH}$ of 7.08 , and dissolved oxygen (DO) of $40 \%$ air saturation. Agitation was at $200 \mathrm{rpm}$ using the standard 3-bladed Applikon pitched-blade impeller. pH was maintained through addition of $\mathrm{CO}_{2}$ sparged gas or $1 \mathrm{~N}$ sodium bicarbonate (VWR). Dissolved oxygen levels were maintained through sparging with air, and if needed oxygen. Once sufficient cell mass was generated, cell were concentrated either through external centrifugation, acoustic perfusion, or tangential flow filtration. Satellite cultures were periodically pulled from the bioreactor aseptically then subsequently maintained as shaker cultures. Transfections were conducted using the same ratio of cell/DNA/PEI as shaker flask transfections. Transfected cells were maintained in the bioreactor at $31^{\circ} \mathrm{C}, 200 \mathrm{rpm}, \mathrm{pH}$ of 7.08 , and $\mathrm{DO}$ of $40 \%$ air saturation.

\subsubsection{Cell separation techniques}

\subsubsection{Centrifugation}

For centrifugation, cell suspension was centrifuged at 3k rpm for $8 \mathrm{~min}$ on a 5682 Benchtop Centrifuge (Forma), then resuspended in an appropriate volume of media.

\subsubsection{Acoustic perfusion}

Cells were separated from media by acoustic perfusion using a BioSep 10L system (AppliSens, Applikon). Operating parameters were $1 \mathrm{~min} / 3 \mathrm{secs}$ of operation/back-flush, respectively, at the highest frequency possible. The percentage separation efficiency (SE) was calculated based on the ratio of the cell concentrations in the outflow and reactor, i.e., SE $=100 *\left(\mathrm{X}_{\mathrm{vr}}-\mathrm{X}_{\mathrm{vp}}\right) / \mathrm{X}_{\mathrm{vr}}$ 
where SE is the separation efficiency (\%), $\mathrm{X}_{\mathrm{vr}}$ is the viable cell concentration in the bioreactor and $\mathrm{X}_{\mathrm{vp}}$ is the viable-cell concentration in the perfusion flow.

\subsubsection{Filtration}

Cell suspension was concentrated through filtration using a tangential flow filter (TFF). This consisted of a $100 \mathrm{kDa}$ MWCO hollow fiber (GE) operated with peristaltic pumps (Masterflex) at $75 \mathrm{ml} / \mathrm{m}^{2 *} \min$.

\subsubsection{Cell, protein and metabolite analysis}

Viable cell density (VCD), viability, and cell size were determined using a Beckman Coulter ViCell Viability Analyzer (Beckman Coulter). Lactate, ammonia, glucose, glutamine, glutamate, and $\mathrm{pH}$ were monitored using a Nova Biomedical Bioprofile 400 Analyzer (Nova Biomedical). Osmolality was measured using a micro osmometer (Advanced Instruments). Supernatant samples were centrifuged, then stored at $-80^{\circ} \mathrm{C}$ for further analysis. Specific growth rate $(\mu)$, in doublings per day, was calculated as change in VCD over a time interval $t_{1}$ to $t_{2}$ (Equation 1.)

$\mu=\frac{\ln \left(V C D_{2} / V C D_{1}\right)}{t_{2}-t_{1}}$

The IgG concentration in the culture medium was determined by sandwich ELISA as previously described (Meissner et al. 2001; Pick et al. 2002). In short, goat anti-human Fc (Sigma, St. Louis, MN) was used for coating the ELISA - plates, and the synthesized IgG fusion protein was detected with Horse Radish Peroxidase (HRP)-conjugated goat anti-human IgG-Fc (Sigma). OPD was used as a substrate for the HRP. Absorption was measured at $450 \mathrm{~nm}$ using a microplate reader (SPECTRAmax340; BioRad, Herceles, CA). 


\subsection{Results and discussion}

\subsubsection{Protein specific variability}

In order to create a model system for TGE, differences in protein expression were investigated. Measuring differences in protein expression are important to understand the inherent biological variability in a TGE process. For this effort, two plasmids of similar sizes that encode for IgG1 antibodies were testing in shaker cultures. One antibody targets the interleukin-8 (IL-8) protein while the other antibody is a SEAP fusion protein with a human Fc domain (pSEAP-Fc). Transfections were conducted holding all variables as similar as possible except for the particularly plasmid gene sequence. The change in gene sequence resulted in significantly different amounts of protein produced between the two conditions (Figure 3.1, Table 3.1). Upon harvest, there was a 14 -fold difference in volumetric productivity of these proteins $(p<0.01)$. There was also a log difference in specific productivity between the two proteins. The IVCD values differed by less than $50 \%$, indicating the protein specific expression rather than the number of expression cells elicited the observed differences.

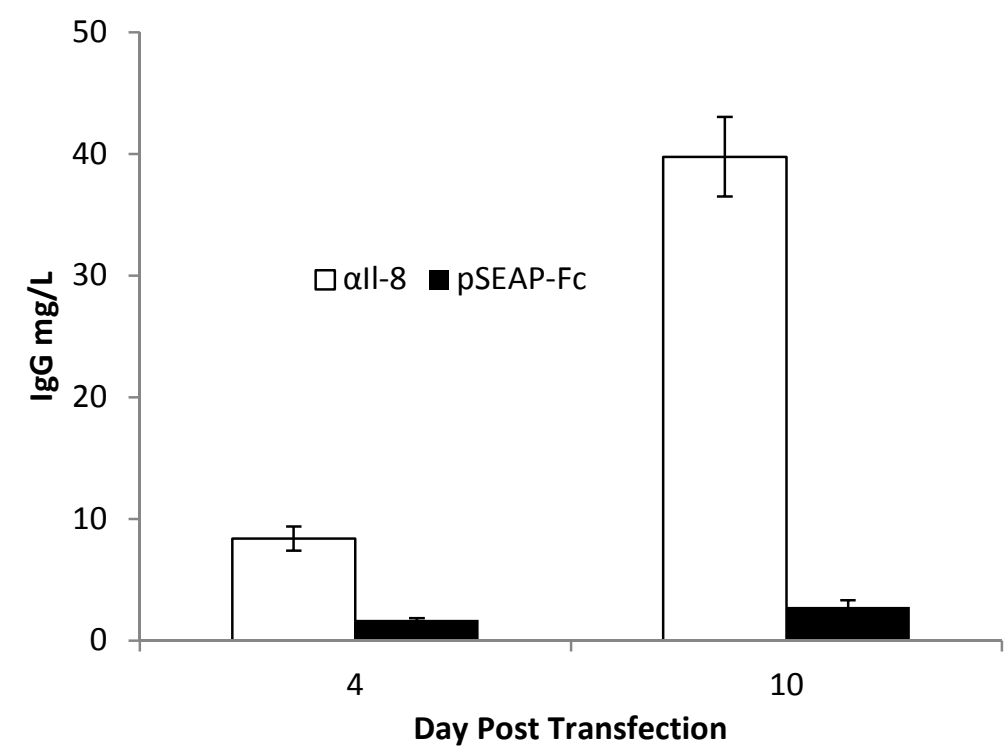

Figure 3.1. Protein specific variability on TGE. 
Shaker flask transfections of CHO-K1 using PEI and various DNA at similar ratios. Error bars represent one standard deviation $(n=3)$

\begin{tabular}{|l|c|c|c|}
\hline \multicolumn{4}{|c|}{ Table 3.1. Protein specific TGE variability } \\
\hline & Titer & IVCD & Qp \\
\hline all-8 & 39.77 & 31.89 & 1.27 \\
\hline SEAP & 2.76 & 22.84 & 0.12 \\
\hline
\end{tabular}

These observations are supported by other studies (Durocher et al. 2002; Girard et al. 2002; Baldi et al. 2005), which found protein expression levels varied between 1 and $20 \mathrm{mg} / \mathrm{L}$ at time of harvest (9 days) in 3-14 L bioreactors, using the same plasmid and transfection protocol. Moreover, fusion proteins have been found to often express with lower titers than standard IgGs (Suen et al. 2010; Cheng 2011). The observed protein specific variability found in this study indicates a novel protein may not express as well as model proteins or other antibodies. Nevertheless, improvements may be able to reduce this variability, such as the development of a specially designed plasmid for transient transfection. Such materials are currently being investigated (Durocher et al. 2002; Geisse and Henke 2005). Furthermore, the primary goal of this work centers on antibody production for immunotherapy.

\subsubsection{Cell-line and media variability}

In order to create a more efficient TGE process, cell line and media formulation were experimentally optimized. To investigate the specific $\mathrm{CHO}$ cell line and media effect on transfection, three similar $\mathrm{CHO}$ cell lines, CHO-S, CHO-K1 and DG44, were tested in a media formulated for transfection (ProCHO) as well as a richer growth media, OptiCHO. Transfections varied among cell lines and media formulations (Figure 3.2). A more minimal, ProCHO transfection media was universally more productive than the richer growth media for 
transfections. CHO-S was the most productive cell line, followed by CHO-K1 and DG44. DG44 was below the limit of quantification on the ELISA assay, but was above the limit of detection, indicating protein was expressed but at a very low level.

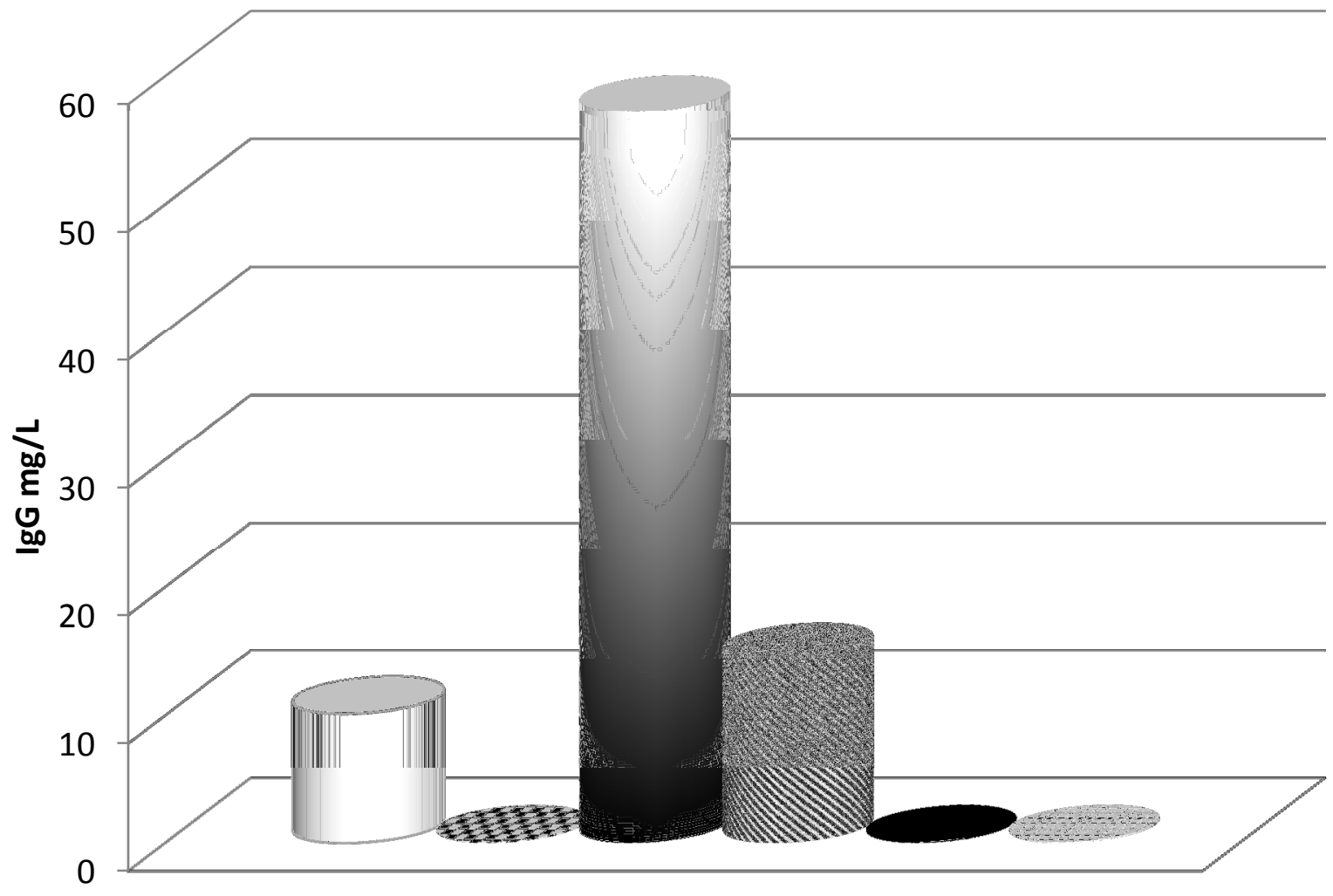

K1 in Pro $\quad \mathrm{K} 1$ in Opti $\quad \mathrm{S}$ in Pro $\mathbf{s}$ in Opti $\quad$ DG44 in Pro $\#$ DG4 in Opti

Figure 3.2. Cell and media effects on TGE performance.

CHO-S (S); CHO-K1 (K) and DG44 (DG44) were transfected in ProCHO media (Pro) or OptiCHO media (Opti) and titer was assessed on day 4.

Only in recent years have attempts to use $\mathrm{CHO}$ cells as hosts for transient transfection processes emerged. A number of $\mathrm{CHO}$ cell lines have been employed, derived from either $\mathrm{CHO}$ K1 wild-type cells or the DHFR-negative variants DG44 and DUKX-B11 (Gottesman 1987; Kao and Puck 1968; Urlaub 1980; Urlaub 1983). CHO cells have been described as prone to genotypic aberrations, and for the DG44 strain a genetic characterization has been recently 
performed in support of this view (Derouazi et al. 2006). Thus, it must be assumed that the different $\mathrm{CHO}$ strains in use in various laboratories may differ considerably in genotype as well as in behavior. Consistent with these studies, cell lines exhibited significant differences in expression in this study. Cell line differences could speculatively be related to either a lower cellular uptake of plasmid DNA, reduced nuclear import or lack of metabolic machinery to enhance expression. DG44, which lack the DHFR gene, exhibited the lowest titer of all cell lines. This metabolic disadvantage may have decreased this cell line's ability to express the protein transiently compared to other cell lines. The optimal system derived from these experiments includes the use of FreeStyle CHO-S cells in ProCHO5 media.

\subsubsection{Aseptic liquid-cell separation techniques}

Results from the media study indicate that ProCHO5 was the optimal transfection media. This advantage is in contrast to OptiCHO's favorable ability to support higher cell densities. An ideal process would expand inoculum in a growth-favorable media, then exchange the media to a more transfection-favorable one, such as ProCHO5. High titer processes often use this strategy but typically conduct these operations using batch centrifugation. This method does not scale above 10 's of liters. In order to develop more scalable systems for media exchange, a number of aseptic liquid-cell separation techniques were tested. These included an acoustic perfusion system and a tangential flow filtration system for transfection in 3-L bioreactors. 


\subsubsection{Acoustic perfusion}

Acoustic perfusion for media exchange in a 3-L bioreactor was not ideal. This was mainly due to the system having less than $50 \%$ separation efficiency during inocoulum expansion (Figure 3.3). This was likely due to gas bubble nucleation, growth, and release within the uptake line, resulting in disruption of cell capture by the acoustic filter. These results are similar for non-optimized systems reported in the literature (Woodside et al. 1998; Crowley et al. 2003; Gorenflo et al. 2005). While optimization of the acoustic system was possible, capacity limitations with this technology (upper limit of approximately 200 to 2000-L bioreactors; Voisard et al. 2003) motivated investigation in a different direction.

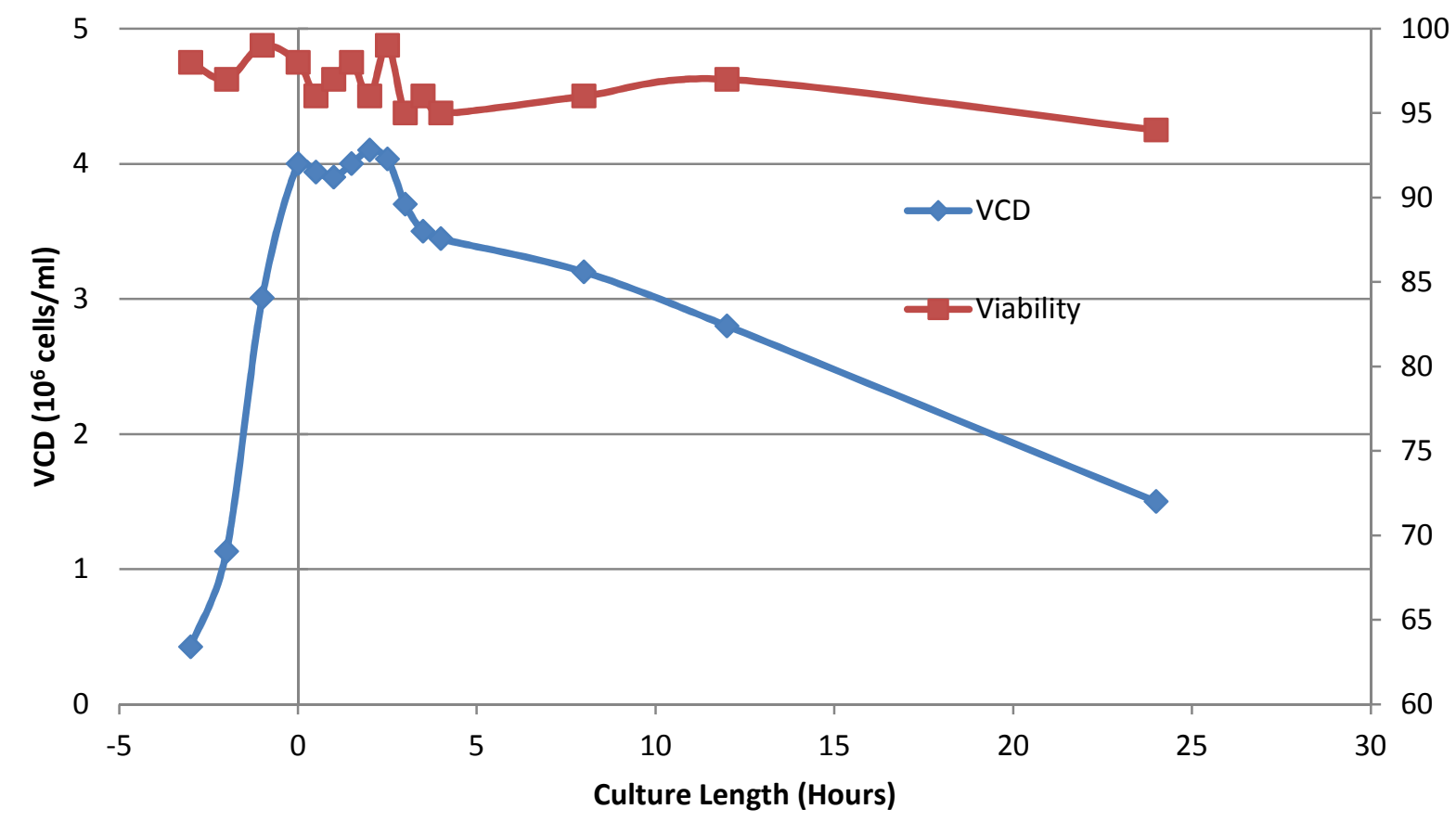

Figure 3.3. Acoustic filtration performance.

Culture was grown in a 3 -L bioreactor. Once cells reached $4 * 10^{6}$ cells/ $\mathrm{ml}($ time $=0)$, the filter was turned on and maintained for a 24 hour period. 


\subsubsection{Tangential flow filtration}

To evaluate the use of a TFF system, filtration induced cell damage had to first be assessed. A 3-L bioreactor was equipped with an autoclavable hollow fiber TFF system. Inoculum culture was expanded then filtered through the hollow fiber. Satellite cultures were pulled from the reactor before filtration began, after 4 hours of filtration, after 8 hours of filtration and after 12 hours of filtration. Satellite cultures were diluted to a similar density using spent media that was collected either from the bioreactor before filtration began (Hour 0 , 4,8 ) or from the permeate line (Hour 12). Satellite cultures were maintained in shaker flasks for 6 days and damage from filtration was assessed through the specific growth rate of the cultivated cells. If cell damage occurred, specific growth rates would have been consistently lower as filtration continued. This effect was not observed from the cultures pulled throughout operation (Figure 3.4), thus filtration did not induce cell damage. Differences between the various treatment groups were more likely a result of pipetting and analytical error rather than biologically significance. 


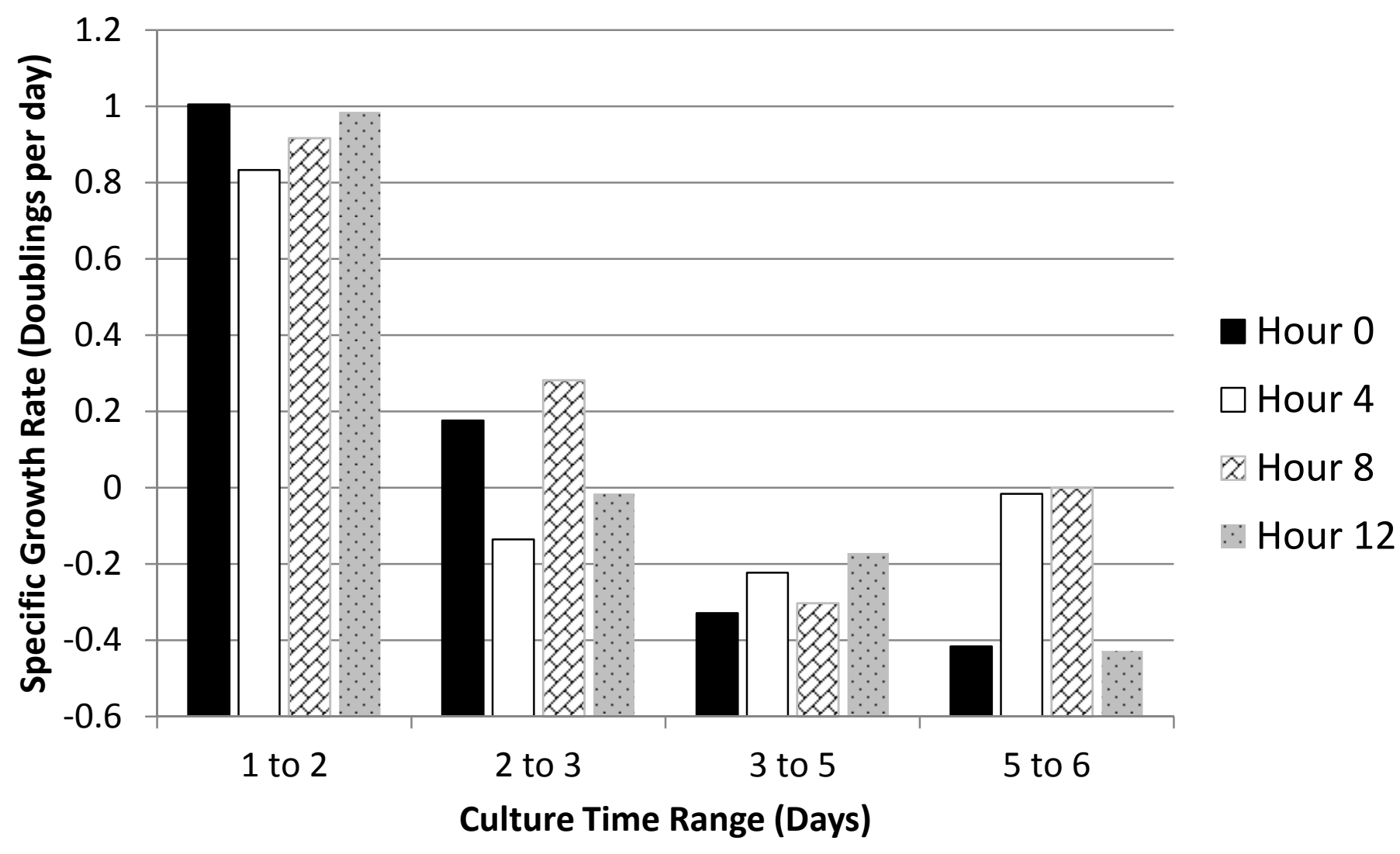

Figure 3.4. Assessment of damage resulting from TFF operations.

Expanded inoculum was filtered using an inline TFF system. Satellite cultures were pulled before operations began (black), 4 hours of filtration (white), 8 hours of filtration (checkered), and after 12 hours of filtration (grey). Cultures were diluted with spent media to a low density to allow cell growth. Specific growth rates were calculated using Equation 1.

Before the TFF system could be used for transfections, the amount of media exchange required to enable highly efficient processes was necessary. This effort was conducted by transfecting cells in fresh media, spent media and a 50-50 mixture of the two. Inoculum was expanded in 3-L bioreactor. Cells and spend media were removed on day 3 and separated through centrifugation. Cells were resuspended in the various media compositions then transfected in shaker flasks. There was a significant difference in titer for conditioned media 
$(p<0.01)$, while such a trend was not observed in the 50-50 case (Figure 3.5$)$. These experiments indicate that a simple $2 x$ concentration step using filtration, prior to transfection, followed by dilution with fresh medium back up to the original volume, after transfection, may be sufficient to enable high volumetric productivity processes.

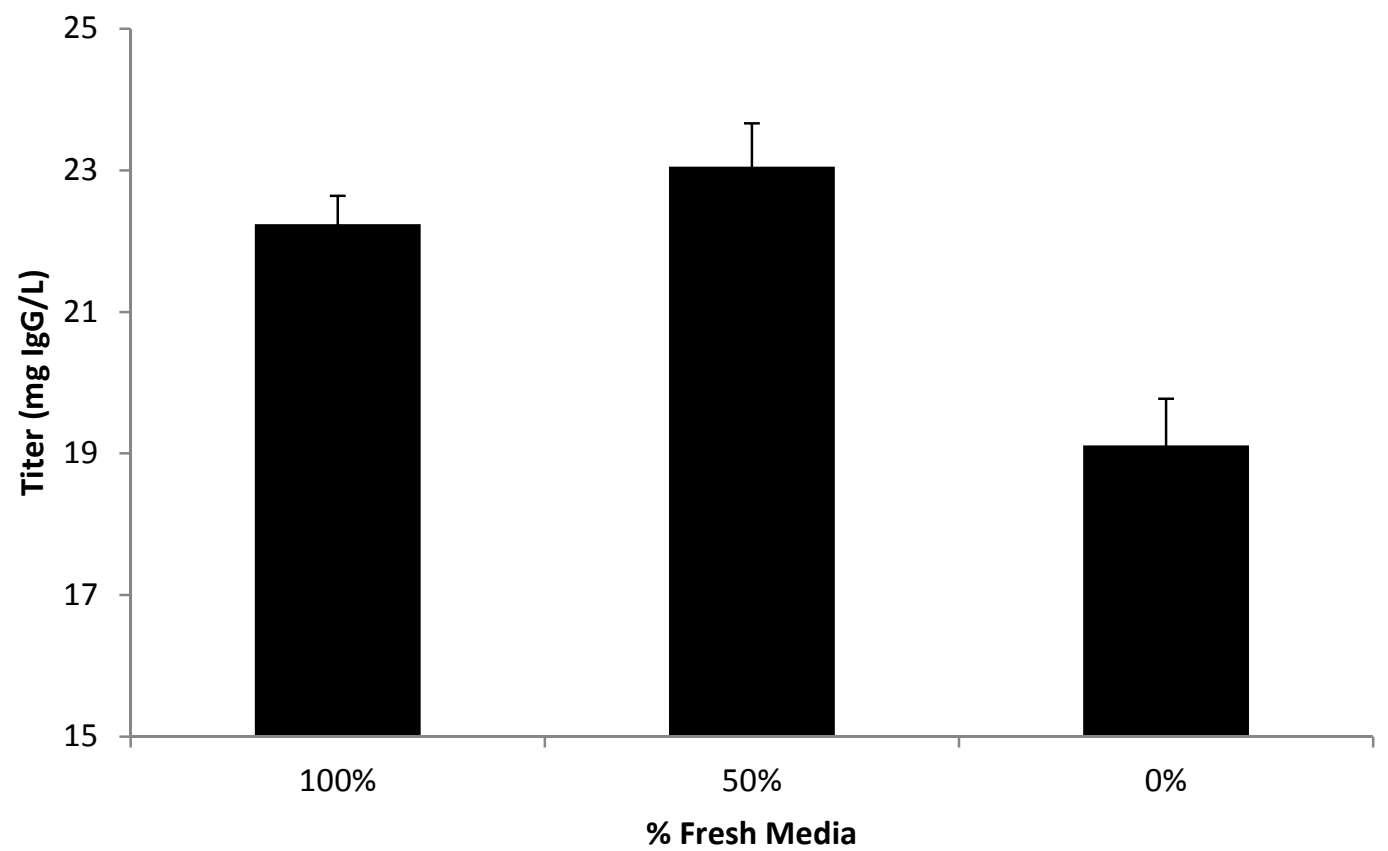

Figure 3.5. Conditioned media effect on transfections.

Transfections were carried out in $125 \mathrm{ml}$ shaker flasks with fresh media, conditioned media or a 50-50 mix of the two. Error bars represent one standard deviation of the mean $(n=3)$

This study found that media formulation significantly affected protein concentration at harvest. This is consistent with previous studies, which have examined a diverse set of media formulations (Codamo et al. 2010). In addition, these experiments observed the use of $100 \%$ conditioned media during transfection resulted in a reduced titer. This observation is also consistent with reported studies in literature (Schlaeger and Christensen 1999; Tuvesson et al. 
2008). Previous studies found that the use of $25 \%$ or more conditioned media in low-celldensity resulted in reduced protein concentrations 72 hours post-transfection. The high-celldensity system in these experiments demonstrate up to $50 \%$ conditioned medium could be used without negatively impacting titer.

Media's influence on transfection is thought to be attributed to the cellular debris accumulation due to cell death, charged species secreted by viable cells, and charged components within the basal media. Cells produce autocrine factors that can have an influence on cell growth (Ozturk and Palsson 1990) and glycosaminoglycans (GAG's) that facilitate cell-cell communication. These molecules accumulate in the medium and it is believed that they might interfere with the transfection process. GAG's in particular, are anionic-polysaccharides commonly found linked to extracellular matrix proteins, so called proteoglycans (PG's), and perform vital roles in cell signaling and cell-cell communication (Linhardt and Toida 2004). Cationic lipid-mediated gene transfer has been found to be inhibited by secreted cellular proteins, in particular PG's (Belting and Petersson 1999). PG's form complexes with cationic lipids/DNA particles, leading to the release of DNA and intracellular accumulation of lipid-PG complexes. This results in inhibition of DNA uptake and a significant reduction in reporter-gene expression (Belting and Petersson 1999; Belting et al. 2005; Gardner et al. 2007). These findings support the observation that use of high levels of conditioned medium can have a negative effect on protein expression.

This study also found that $50 \%$ conditioned media did not significantly reduce protein levels. Tuvesson et al. (2008) found that the use of more than $25 \%$ conditioned media during transfections impairs transfections. These studies however used low density transfections. 
Therefore the concentration of inhibiting species during transfections in this study was likely not high enough to significantly impair transfection. The use of $50 \%$ conditioned media, or a $1 x$ media exchange was found to be sufficient to remove inhibiting components within the media.

The use of rich media, however, has the advantage of supporting high density cultures. Production media in commercial cell culture often can support cell densities in the tens of millions of cells per $\mathrm{ml}$. ProCHO5, however, is only able to support $5^{*} 10^{6}$ cells per $\mathrm{ml}$, and is not ideal for production culture.

\subsubsection{Filtration}

To test the ability for TFF to aseptically separate cells from liquid prior to transfection, a modified 3-L bioreactor was fitted with an inline $100 \mathrm{kDa}$ MWCO hollow fiber unit. Inoculum was expanded in the 3-L bioreactor. When sufficient cell mass was generated, satellite cultures were pulled, centrifuged, resuspended, then transfected and grown in shaker flasks (Cen/Shake set). Subsequent to pulling of the satellite cultures for Cen/Shake set, cross-flow filtration of the cells in the bioreactor was initialized and cells were concentrated $2.5 \mathrm{x}$ without loss in viability and a high separation efficiency $(<98 \%)$. Cells were then fed 2 volumes of fresh media and concentrated down to transfection density. Satellite cultures were pulled from the bioreactor and then transfected and maintained in shaker flasks (Fil/Shake set). Cells remaining in the bioreactor were transfected and subsequently maintained in the bioreactor (Reactor set). After cells were fed, satellite cultures from the bioreactor were pulled and cultivated in a shaker flask (Reactor/Shaker set). Transfection results are shown in Figure 3.6 and Table 3.2. The shaker transfected cultures had significantly lower viability compared to the cultures transfected in the 
bioreactor. In addition, the centrifuged cultures had significantly lower viability compared to other treatment groups. VCD and IVCD demonstrated similar trends, indicating transfections in shaker flasks were more cytotoxic than in the bioreactor. In addition, the bioreactor maintained a higher viable-cell-mass than any other culture (IVCD of 68.3). Titer was similar among the centrifuged and filtered cells, indicating TFF as a separation technique was successful. Titer differences were significant between the shaker transfected cells and the bioreactor cells maintained in the shaker flask $(p<0.01)$. The reactor, on the other hand had the highest titer with $304 \mathrm{mg} / \mathrm{L}$. Specific productivity varied over 4 fold between the cultures, where the centrifuged culture had the highest $Q_{p}$ of $10.7 \mathrm{pg} / \mathrm{cell}$ day. The lowest $\mathrm{Qp}$ was the Reactor/Shaker set (2.78 pg/cell day).

\section{A}

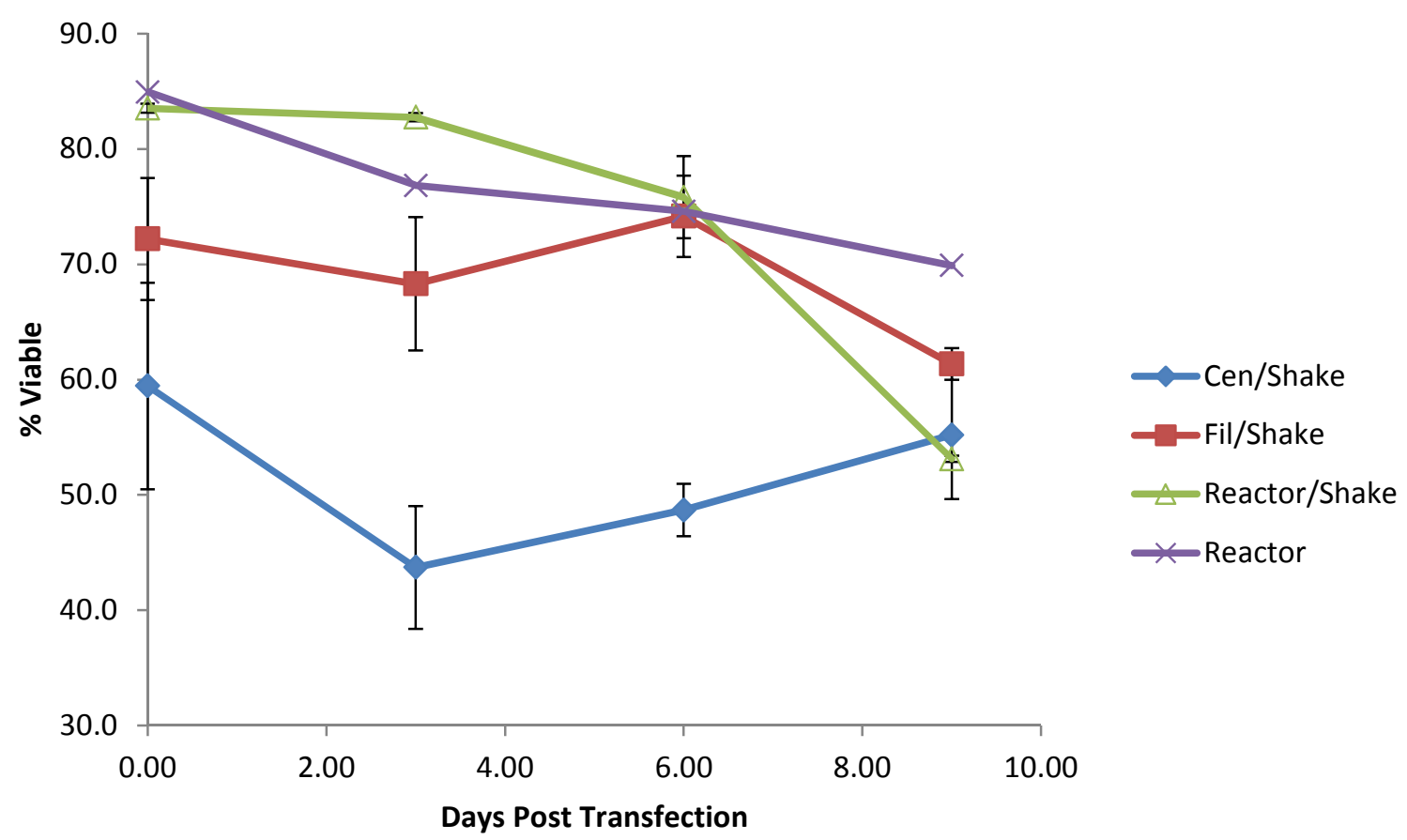




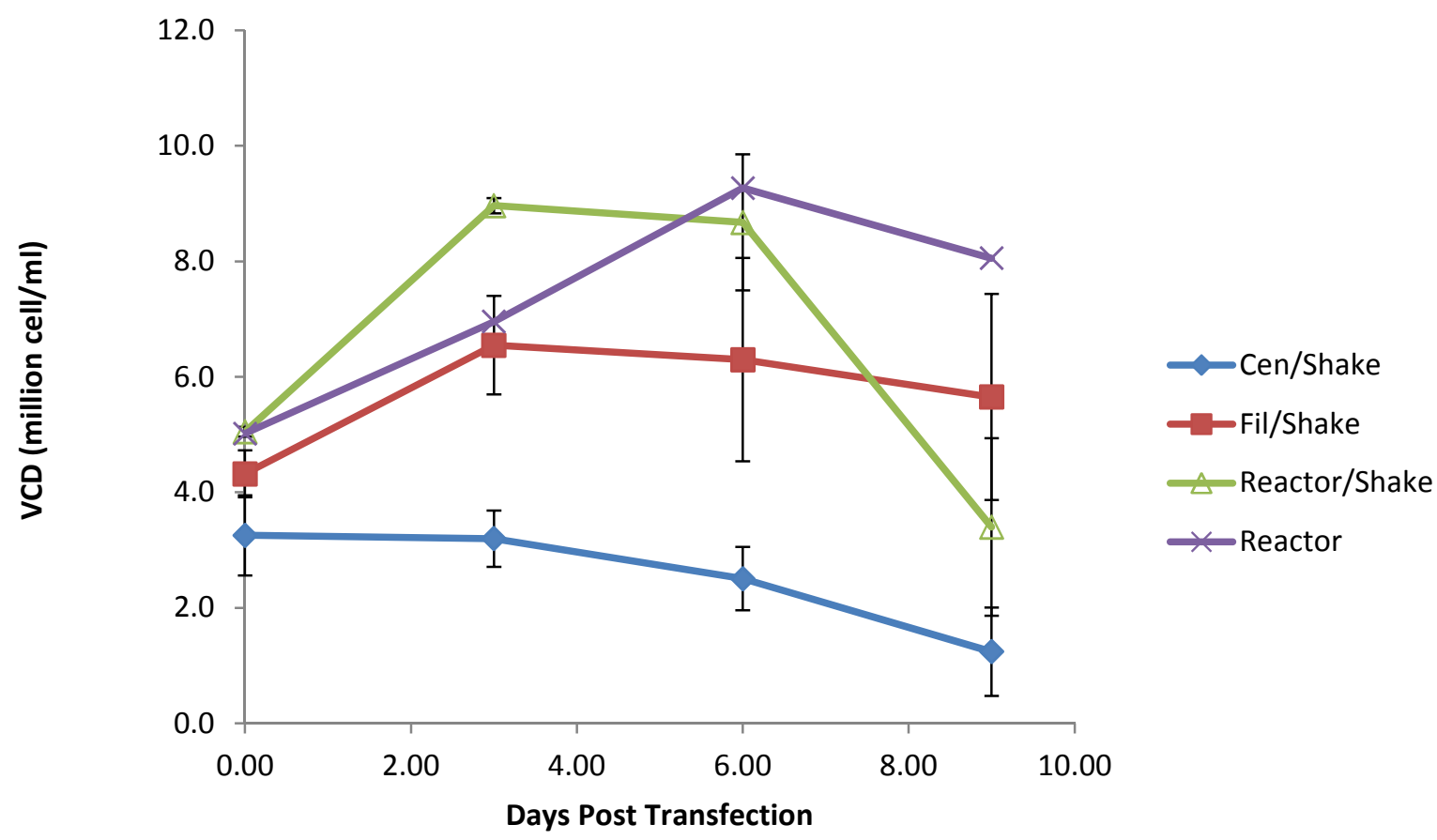

Figure 3.6. Transfection of cells using scalable unit operations.

A) Viability of the transfections B)Viable cell density of the transfections. Error bars represent one standard deviation of the mean $(n=3)$, except for the reactor condition which was a single culture.

\begin{tabular}{|lccc|}
\hline \multicolumn{4}{|c|}{ Table 3.2. Transfection of cells using scalable unit operations } \\
\hline & IVCD & Titer & Qp \\
\hline Cen/Shake & $24.1 \pm 4.3$ & $258 \pm 16$ & $10.7 \pm 0.6$ \\
\hline Fil/Shake & $56.0 \pm 7.0$ & $255 \pm 12$ & $4.55 \pm 0.5$ \\
\hline Reactor/Shake & $65.7 \pm 6.5$ & $183 \pm 17$ & $2.78 \pm 0.6$ \\
\hline Reactor & 68.3 & 304 & 4.45 \\
\hline
\end{tabular}

\subsection{Conclusion}

This study sought to generate an optimal transfection protocol using $\mathrm{CHO}$ cells that could potentially scale to the 000 's of liter scale. Many groups have investigated the variables involved in the transfection process to identify high titer TGE processes (Figure 3.7; Elouahabi 
and Ruysschaert 2005; Godbey et al. 1999; Galbraith et al. 2006; Tait et al. 2004; Bertschinger et al. 2008).

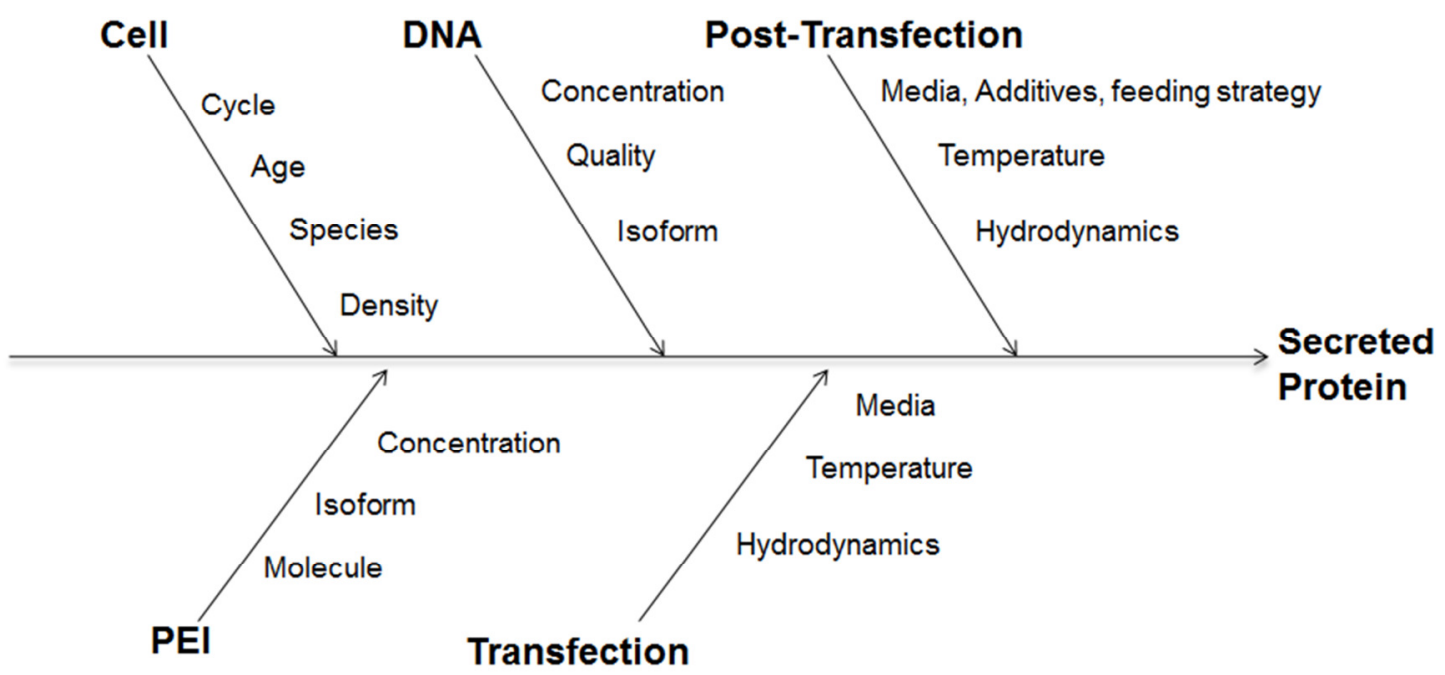

Figure 3.7. Fish bone diagram of the variables involved in TGE.

This work investigated a novel set of variables to generate an optimized TGE protocol. The final method included the use of CHO-S cells in ProCHO5 media using an all-8 antibody. In addition, this process was implemented into a scalable system using TFF that allowed transfection to occur in the same bioreactor as inoculum expansion. This process may provide a superior alternative as the operational complexity is dramatically reduced. Moreover, TFF bioreactors provided the highest titer reported in CHO-TGE cultures (Figure 3.8). 


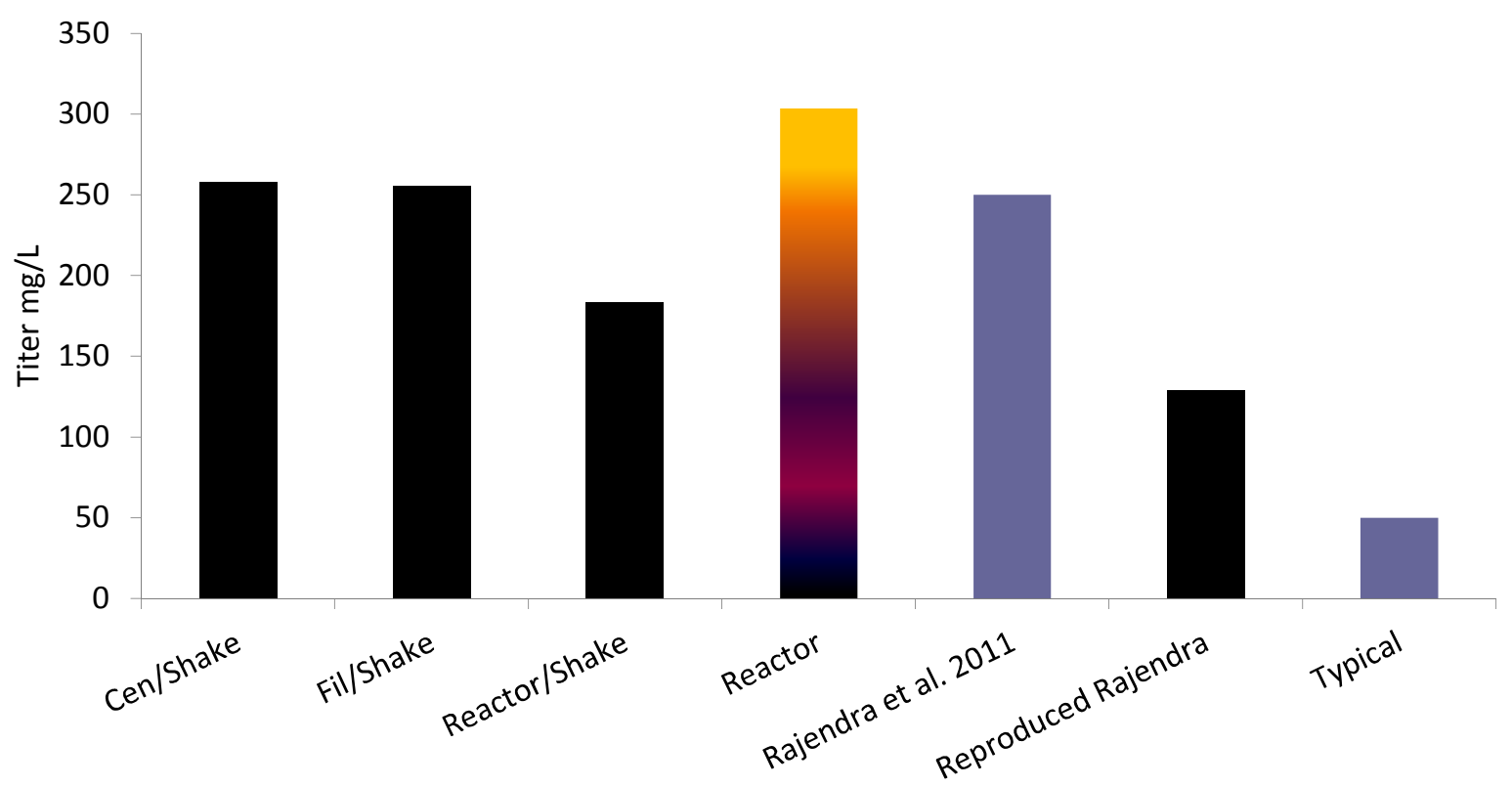

Figure 3.8. Comparison of reported CHO-TGE culture titers.

Shown in black are cultures conducted here at KGI, whereas the blue cultures are found in the literature. Note; Outside of this work, Rajendra et al. 2011 has the highest reported titer $(250 \mathrm{mg} / \mathrm{L})$ for CHO based TGE cultures greater than $30 \mathrm{mls}$.

\subsection{References}

Baldi L.; Muller N.; Picasso S.; Jacquet R.; Girard P.; Thanh H. P.; Derow E.; Wurm F. M. Transient gene expression in suspension HEK-293 cells: application to large scale protein production. Biotechnol. Prog. 2005 (21) 148-53

Baldi L.; Hacker D. L.; Adam M.; Wurm F. M. Recombinant protein production by large-scale transient gene expression in mammalian cells: state of the art and future perspectives. Biotechnol. Lett. 2007, 29 (5) 677-84

Bertschinger M, Schertenleib A, Cevey J, Hacker D and Wurm F, The Kinetics of polyethylenimine-mediated transfection in suspension cultures of Chinese hamster ovary cells. Mol Biotechnol 40:136-143 (2008).

Belting M. and Petersson P. Intracellular accumulation of secreted proteoglycans inhibits cationic lipid-mediated gene transfer. Co-transfer of glycosaminoglycans to the nucleus. J. Biol. Chem. 1999, 274 (27) 19375-82

Belting M.; Sandgren S.; Wittrup A. Nuclear delivery of macromolecules: barriers and carriers. Adv. Drug Deliv. Rev. 2005, 57(4):505-27 
Bieber T.; Meissner W.; Kostin S.; Niemann A.; Elsasser H. P. Intracellular route and transcriptional competence of polyethylenimine-DNA complexes. J. Control Release 2002 (82) 441-54

Brunner S.; Furtbauer E.; Sauer T.; Kursa M.; Wagner E. Overcoming the nuclear barrier: cell cycle independent nonviral gene transfer with linear polyethylenimine or electroporation. Mol. Ther. 2002 (5) 80-6

Carpentier E.; Paris S.; Kamen A. A.; Durocher Y. Limiting factors governing protein expression following polyethylenimine mediated gene transfer in HEK293-EBNA1 cells. J Biotechnol 2007, 128 (2) 268-80

Cheng, Lu. Transient gene expression of a mouse homolog of FcE-Fcy fusion protein for antiallergic function assay". Process biochem. 2011(1991) (1359-5113), 46 (4), p. 858

Codamo J. Hou J. J. C.; Hughes B. S.; Gray P. P.; Munro T. P. Efficient mAb production in CHO cells incorporating PEI-mediated transfection, mild hypothermia and the co-expression of XBP1. J Chem Technol Biotechnol. 2011 (86) 923-34

Crowley J.; Schlukebir C.; Dijkstal M.; Hoeksma S.; Olthof E.; Hubmann S.; Esser S.; Herrmann A.; Martin J. M. C.; Hof R. CGMP manufacture of a fusion protein in mammalian cells using a largescale acoustic perfusion system. Proceedings of the $18^{\text {th }}$ ESACT Meeting 2003; Animal cell technology meets genomics.

D'Anna, J. A. (1996) Methods in Cell Science 18, 115

D'Anna, J. A., Valdez, J. G., Habbersett, R. C., and Crissman, H. A. (1997) Association of G1/Sphase and late S-phase checkpoints with regulation of cyclin-dependent kinases in Chinese hamster ovary cells. Radiat Res 148, 260-271.

Deaven, L. L., and Petersen, D. F. (1973) The chromosomes of CHO, an aneuploidy Chinese hamster cell line: G-band, C-band, and autoradiographic analyses. Chromosoma 41, 129-144.

Durocher Y.; Perret S.; Kamen A. High-level and high throughput recombinant protein production by transient transfection of suspension-growing human 293-EBNA1 cells. Nuc. Acid Res. 2002 30: E9

M. Derouazi, D. Martinet, N.B. Schmutz, R. Flaction, M. Wicht, M. Bertschinger, D.L. Hacker, J.S. Beckmann, F.M. Wurm, Genetic characterization of CHO production host DG44 and derivative recombinant cell lines, Biochem. Biophys. Res. Commun. 340 (2006) 1069-1077

Elouahabi A. and Ruysschaert J. M. Formation and intracellular trafficking of lipoplexes and polyplexes. Mol. Ther. 2005 (11) 336-47 
Escriou V.; Carriere M.; Bussone F.; Wils P.; Scherman D. Critical assessment of the nuclear import of plasmid during cationoic lipid-mediated gene transfer. J. Gene Med. 2001 (3) 179-87

Galbraith D. J.; Tait A. S.; Racher A. J. Control of culture environment for improved polyethyleniminemediated transient production of recombinant monoclonal antibodies by $\mathrm{CHO}$ cells. Biotechnol. Prog. 2006 (22) 753-62

Gardner R. A.; Belting M.; Svensson K. Synthesis and transfection efficiencies of new lipophilic polyamines. J. Med. Chem. 2007, 50 (2) 308-18

Geisse S.; Jordan M.; Wurm F. M. Large-scale transient expression of therapeutic proteins in mammalian cells. Meth. Mol. Biol. 2005 (308) 87-98

Geisse S. and Fux C. Recombinant protein production by transient gene transfer into mammalian cells. Chapter 15 in Meth. Enzym. 2009, (463) 223-38

Geisse S. Reflections of more than 10 years of TGE approaches. Pro. Exp. Purif. 2009 (64) 99-107

Girard P.; Derouazi M.; Baumgartner G. et al 100-Liter transient transfection. Cytotechnology 2002 (38) 15-21

Godbey W. T.; Wu K. K.; Mikos A. G. Poly(ethylenimine) and its role in gene delivery. J. Control Release 1999 (60) 149-60

Gottesman M. M. Chinese hamster ovary cells, in: M. Gottesman (Ed.), Meth. Enzym., Academic Press Inc., San Diego, 1987, pp. 3-8.

Gorenflo V. M.; Ritter J. B.; Aeschliman D. S.; Drouin H.; Bowen B. D.; Piret J. M. Characterization and optimization of acoustic filter performance by experimental design methodology. Biotechnol. Bioeng. 2005, 90 (6) 746-53

Hacker D. L.; De Jesus M; Wurm F. M. 25 years of recombinant proteins from reactor-grown cells. Where do we go from here? Biotechnol. Advances 2009, (27) 1023-127

Jordan M. I.; Köhne C.; Wurm F. M. Calcium-phosphate mediated DNA transfer into HEK-293 cells in suspension: control of physicohemical parameters allows transfection in stirred media. Cytotechnology 1998 (26) 39-47

Kao F. T. and T.T. Puck, Genetics of somatic mammalian cells. VII. Induction and isolation of nutritional mutants in Chinese hamster cells, Proc. Natl. Acad. Sci. USA 1968 (60)1275-81

Kichler A. Gene transfer with modified polyethylenimines, J. Gene Med. 2004, 6 (Suppl. 1) S3S10. 
Kopatz L.; Remy J. S.; Behr J. P.; A model for non-viral gene delivery: through syndecan adhesion molecules and powered by actin. J. Gene Med. 2004 (6) 769-76

Lee J. C.; Kim D. Y.; Oh D. J.; Chang H. N. Two-Stage Depth Filter Perfusion Culture for Recombinant Antibody Production by Recombinant Chinese Hamster Ovary Cell. Biotechnol. Bioeng 2008, 13: 560-5

Linhardt RJ, Toida T (2004) Role of glycosaminoglycans in cellular communication. Acc. Chem. Res. 2004 (37) 431-8

Liu, S. Harvey, M.R. Madlansacay, K. McLean, M.P. Rosser, J. MacRobbie, C.L. Olsen, R.R. Cobb, High levels of protein expression using different mammalian CMV promoters in several cell lines. Protein Expr. Purif. 2006 (45) 115-24

Ozturk S. S. and Palsson B. O. (1990) Effect of initial cell density on hybridoma growth, metabolism, and monoclonal antibody production. J. Biotechnol. 1990, 16(3-4) 259-78

Pham P. L.; Perret S.; Doan H. C.; Cass B.; St-Laurent G.; Bisson L.; Kamen A.; Durocher Y. Largescale transient transfection of serum-free suspension-growing HEK293 EBNA1 cells: peptone additive improve cell growth and transfection efficiency. Biotechnol. Bioeng. 2003 (84) 332-42

Pham P. L.; Kamen A.; Durocher Y. Large-scale transfection of mammalian cells for the fast production of recombinant protein. Mol. Biotechnol. 2006, 34 (2) 225-37

Puck TT, Cieciura SJ, Robinson A (1958) Genetics of somatic mammalian cells. III. Long-term cultivation of euploid cells from human and animal subjects. J Exp Med 108(6):945-56.

Urlaub $\mathrm{G}$ and Chasin L. A.; Isolation of Chinese hamster cell mutants deficient in dihydrofolate reductase activity. Proc. Natl. Acad. Sci. USA 1980 (77) 4216-20

Urlaub G.; Käs E.; Carothers A. M.; Chasin L. A. Deletion of the diploid dihydrofolate reductase locus from cultured mammalian cells. Cell 1983 (33) 405-12

Schlaeger E. J. and Christensen K. Transient gene expression in mammalian cells grown in serum-free suspension culture. Cytotechnology 1999 (30) 71-83

Schlaeger E. J.; Kitas E. A.; Dorn A. SEAP expression in transiently transfected mammalian cells grown in serum free suspension culture. Cytotechnology 2003 (42) 47-55

Shi C.; Shin Y. O.; Hanson J.; Cass B.; Loewen M. C.; Durocher Y. Purification and characterization of a recombinant G-protein-coupled receptor, Saccharomyces cerevisiae Ste $2 p$, transiently expressed in HEK293 EBNA1 cells. Biochemistry 2005 (44) 15705-14 
Tait A. S.; Brown C. J.; Galbraith D. J.; Hines M. J.; Hoare M.; Birch J. R.; James D. C. Transient production of recombinant proteins by Chinese hamster ovary cells using polyethyleneimine/DNA complexes in combination with microtubule disrupting anti-mitotic agents, Biotechnol. Bioeng. 2004 (88)707-21

Tuvesson O.; Uhe C.; Rozkov A.; Lüllau E. Development of a generic transient transfection process at $100 \mathrm{~L}$ scale. Cytotechnololgy 2008 (56) 123-36

Voisard D.; Meuwly F.; Ruffieux P. A.; Baer G.; Kadouri A. Potential of Cell Retention Techniques for Large-Scale High-Density Perfusion Culture of Suspended Mammalian Cells. Biotechnol. Bioeng. 2003, 82 (7) 751-65

Wulhfard S.; Tissot S.; Bouchet S.; Cevey J.; De Jesus M.; Hacker D. L.; Wurm F. M. Mild hypothermia improves transient gene expression yields several fold in Chinese hamster ovary cells, Biotechnol. Prog. 2008 (24) 458-65

Wurm F. M. and Bernard A. Large-scale transient expression in mammalian cells for recombinant protein production. Curr. Opin. Biotechnol. 1999, 10 (2) 156-9

Wurm F. M. 2004. Production of recombinant protein therapeutics in cultivated mammalian cells. Nat. Biotechnol. 2004, 22 (11) 1393-8

W. Xia, P. Bringmann, J. McClary, P.P. Jones, W. Manzana, Y. Zhu, S. Wang, Y.

Ye J.; Kober V.; Tellers M.; Naji Z.; Salmon P.; Markusen J. F.. 2008. High-Level Protein Expression in Scalable CHO Transient Transfection. Biotechnol. Bioeng. 2009 (103) 542-51

Zhao Y.; Bishop B.; Clay J. E.; Lu W.; Jones M.; Daenke S.; Siebold C.; Stuart D. I.; Jones Y.; Aricescu A. R. Automation of large scale transient protein expression in mammalian cells. J. Struct. Biol. 2011 (175) 209-15 


\title{
CHAPTER 4. PROCESSES SIMULATION FOR LARGE-SCALE TRANSIENT GENE EXPRESSION
}

\author{
Abstract \\ Rapid, large scale production of monoclonal antibodies is necessary for bio-defense needs. \\ Current production systems do not fulfill this need as they suffer from either not producing \\ satisfactory high-quality antibodies, or not producing antibodies within a relevant timeline. One \\ solution to this unmet medical need is the use transient gene expression in Chinese hamster \\ ovary $(\mathrm{CHO})$ cell culture, utilizing large scale industrial bioreactors. In this study, we aimed to \\ assess the feasibility of such an approach through process simulation. SuperPro flow sheets \\ were generated representing the most up to date methods in transient antibody production. \\ After calibration of key parameters, the model calculated a facility with 200,000 -L bioreactor \\ capacity and would produce between 32 and 1,274 kg of high-quality antibody within 12 weeks. \\ Production output was primarily dependent on volumetric productivity. Similarly, cost of \\ manufacturing recombinant protein was dependent on volumetric productivity, and was \$164 \\ per gram for a process that would meet bio-defense needs of 1,200 kg. Increases beyond 500 \\ $\mathrm{mg} / \mathrm{L}$ in volumetric productivity provided marginal reductions in the cost of production. Lab \\ scale bioreactor studies provided better parameter estimates, which were used to refine large \\ scale simulation. Results of this work demonstrate the feasibility of meeting bio-defense needs \\ through the use of large-scale, transient gene expression.
}




\subsection{Introduction}

The production of recombinant proteins (r-proteins) is an emerging technology with a central focus on medical applications. Many therapeutic biopharmaceutical r-proteins are complex molecules that need to be post-translationally modified for full bioactivity, especially monoclonal antibodies (mAbs). These modifications are performed optimally by mammalian cell culture, especially Chinese hamster ovary (CHO) cells (Wurm 2004). Pharmaceutical companies routinely establish stable recombinant cell lines that predictably produce $r$-proteins for extended cultivation times. This form of production, often called stable gene expression (SGE), is achieved through the insertion of recombinant genes into the host genome. Identification and characterization of these cell lines is, however, a costly and time-consuming process (Baldi et al. 2007). Faster approaches to r-protein production are necessary for rapid production capabilities, such as passive antibody administration for use in mass-casualty biological catastrophes (Casadevall 2002; DARPA 2006; Tether 2010).

The bio-defense market has previously been described in detail (Chapter 1). Briefly, the Defense Advanced Research Program Agency (DARPA) describes three milestones for biodefense production capability. These are 12, 120 and 1,200 kg of high-quality, monoclonal antibody produced within a three month window (DARPA 2006). Transient gene expression (TGE) is well-suited to fill this need. In contrast to stable gene expression, TGE involves shortterm r-protein production typically for up to 14 days post-transfection in the absence of genetic selection of the plasmid DNA. Recent advances in TGE have successfully provided high-titer production processes (gram/L) at smaller scales (<10 L) (Backliwal et al. 2008; Geisse and Fux 2009; Hacker et al. 2010). For mass casualty events where medical countermeasures are 
needed, these systems could potentially be scaled to industrial size bioreactors $(25,000 \mathrm{~L})$ to produce significant amounts of antibody based medical countermeasures. Because of idle capacity within the biomanufacturing industry (Levine 2010), this scenario may become a reality. A better understanding of the possible output of such a large scale production process would provide greater incentive for investment from both public and private sector stakeholders.

In order to do this modeling, process simulation was conducted based off of current TGE processes in SuperPro Designer software to elucidate this possibility. Process simulation allows for advanced forecasting, planning and comparison of various processes and facilities under a range of different production levels, cost structures and process efficiencies (Simpson 2011). Utilizing process simulation, the goal of this work is to characterize the potential of a large scale TGE processes to fulfill the needs of bio-defense in the event of a biological catastrophe.

\subsection{Model}

Many commercial antibodies are manufactured using similar processes (Farid 2001; Wurm 2004; Sommerfeld and Strube 2005; Farid 2006; Birch et al. 2006); the majority use batch/fed-batch mammalian cell culture followed by purification steps that rely primarily on chromatography with intermediate filtration and viral clearance operations (Figure 4.1A). TGE methods utilize similar unit operations (Tuvesson et al. 2008; Geisse and Fux 2009) with the addition of a cell concentration and medium exchange step (Figure 4.1B). 


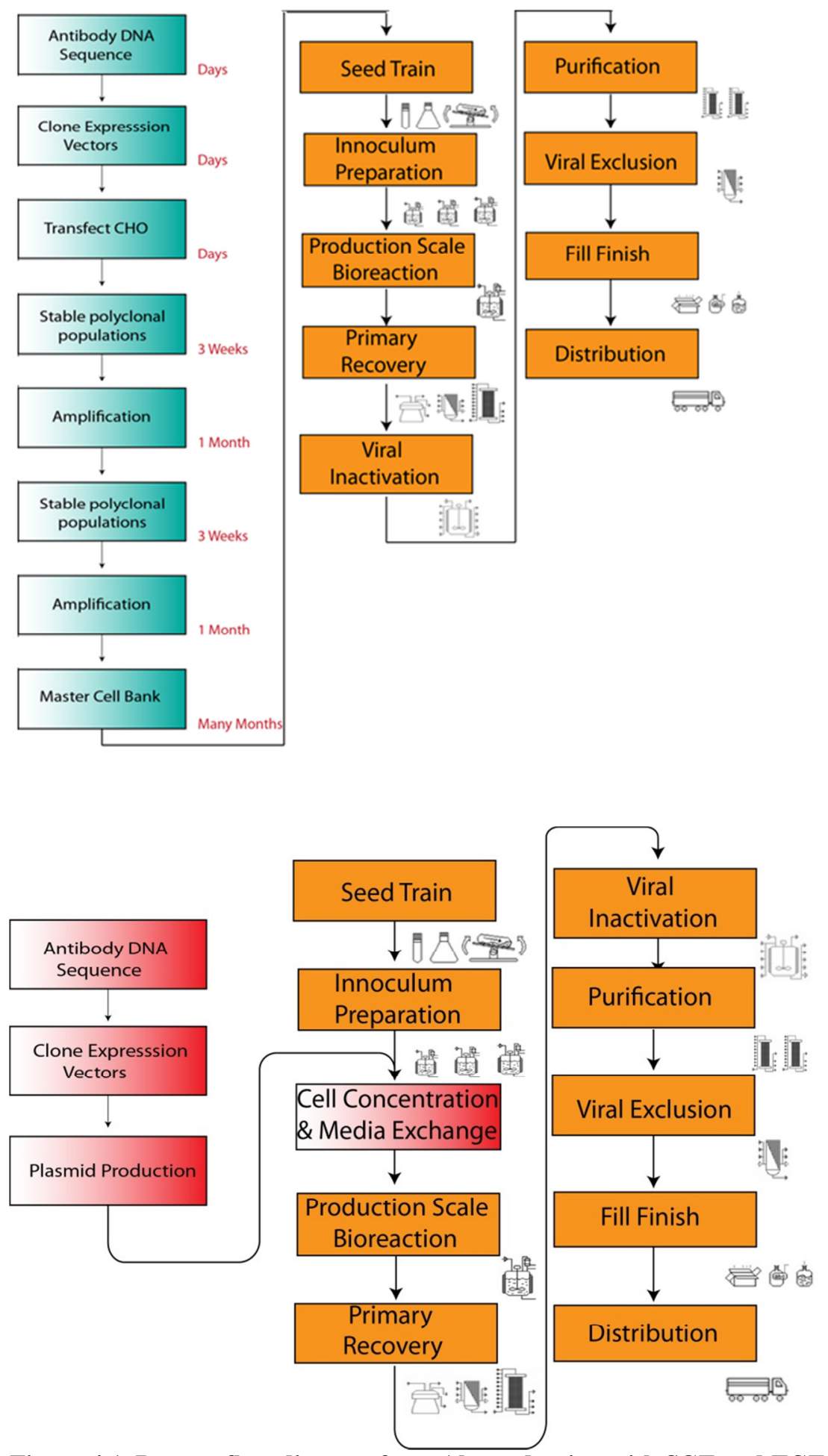

Figure 4.1. Process flow diagram for mAb production with SGE and TGE

SGE is shown in A and TGE is shown in B. Molecular biology operations are shaded in green, while commercial manufacturing operations are shaded yellow. Differences between stable and transient gene expression processes are shaded red. 


\subsubsection{Building a model}

A deterministic flow sheet containing a schematic representation of all unit operations that must be performed to convert raw materials into final antibody product was generated using SuperPro Designer version 7.0 (Intelligen). This flow sheet (Figure 4.2) is an adaptation from previously reported models (Heinzle et al. 2006; Harrison et al. 2006; Abramzon and Croughan 2007). Although the size of the equipment has changed to represent a $25,000 \mathrm{~L}$ cell culture process, the sequence of unit operations remains unaltered. This model includes cell culture, primary recovery, protein-A capture, chemical virus inactivation, purification through anionic exchange column chromatography and hydrophobic interaction chromatography, viral exclusion, and fill finish operations. For a detailed description of unit operations and their parameters, see Appendix. 

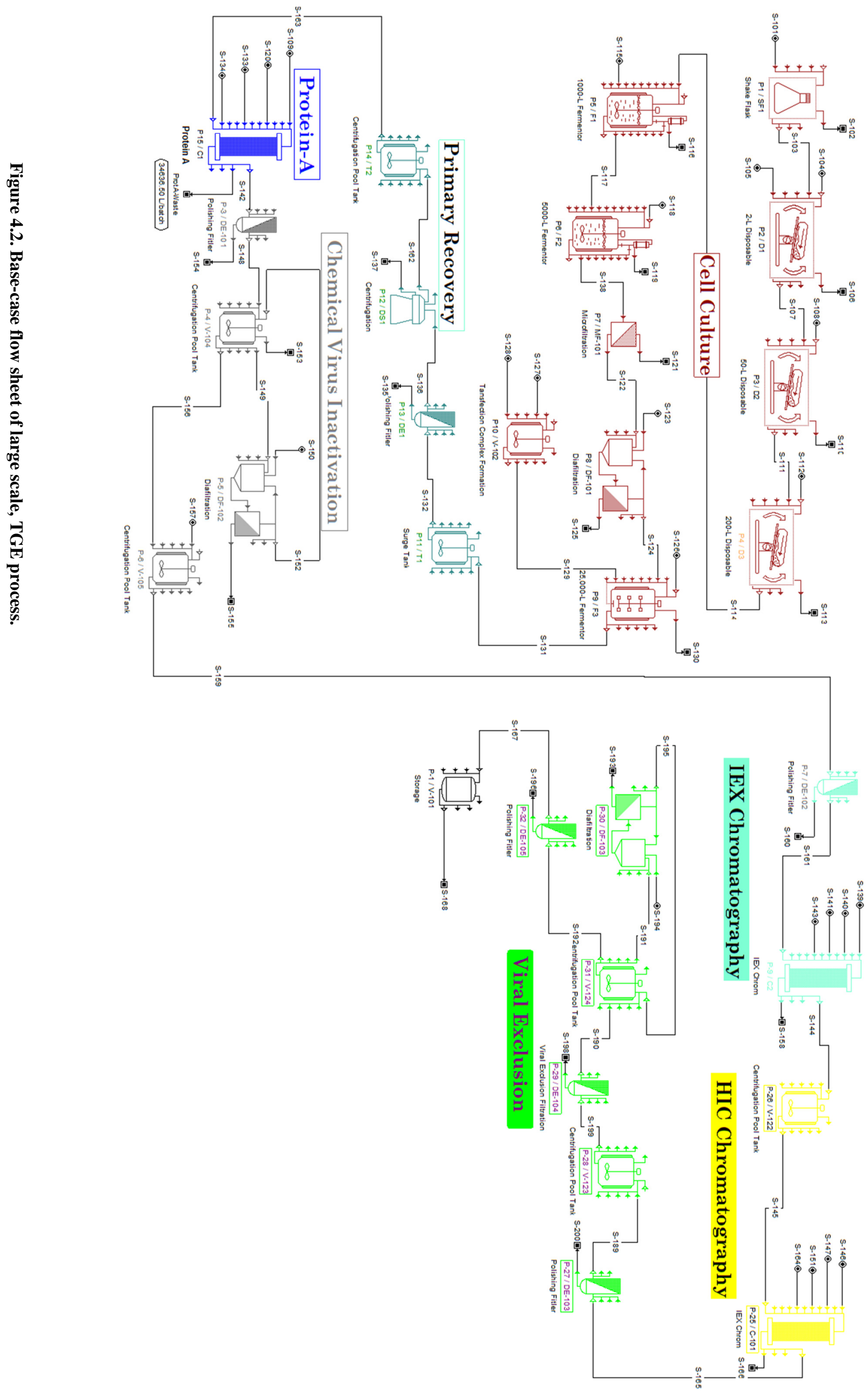


\subsubsection{Calibrating the model}

After creating the flow sheet, the model must be calibrated to represent realistic costs, cycle times and yields. Two key parameters to calibrate model output were capital investment required to build or acquire the plant and the cost of manufacturing r-proteins. Capital investment refers to the cost for the facilities which house the manufacturing equipment as well as the large, fixed asset, items used during the manufacturing process. Benchmarks for cell culture capital investment can be found in literature as well as anecdotal report from biomanufacturing professionals (Table 4.1; Fraid 2006).

Table 4.1. Capital investment costs for cell culture facilities producing antibodies Adapted from Farid 2006

\begin{tabular}{|c|c|c|c|c|c|c|}
\hline \multirow[t]{2}{*}{ Manufacturing Facility } & \multirow[t]{2}{*}{$\begin{array}{l}\text { Date facility } \\
\text { completed }\end{array}$} & \multirow{2}{*}{$\begin{array}{l}\text { Capital } \\
\text { investment } \\
\text { (US \$M) }\end{array}$} & \multirow[t]{2}{*}{ Area $\left(\mathrm{ft}^{2}\right)$} & \multicolumn{3}{|c|}{ Production bioreactor capacity } \\
\hline & & & & Number & $\begin{array}{c}\text { Size } \\
(000 \text { 's L) }\end{array}$ & $\begin{array}{c}\text { Total } \\
\text { (000's L) }\end{array}$ \\
\hline Genentech-Vacaville, CA, USA & 2000 & 250 & 310000 & 8 & 12 & 96 \\
\hline Imclone- Branchburg BB36, NJ, USA & 2001 & 53 & 80000 & 3 & 10 & 30 \\
\hline Abiogen- LSM, RTP, NC, USA & 2001 & 175 & 245000 & 6 & 15 & 90 \\
\hline Boehringer Ingelheim expansion- Biberach, Germany & 2003 & 315 & na & 6 & 15 & 90 \\
\hline Lonza biologics expansion- Portsmouth, NH, USA & 2004 & 207 & 270000 & 3 & 20 & 60 \\
\hline Amgen- BioNext, West Greenwich, RI, USA & 2005 & 500 & 500000 & 9 & 20 & 180 \\
\hline Genentech- NIMO- Oceanside, CA, USA & 2005 & 380 & 470000 & 6 & 15 & 90 \\
\hline Imclone- Branchburg BB50, NJ, USA & 2005 & 260 & 250000 & 9 & 11 & 99 \\
\hline Biogen Idec- Hillerod, Denmark & 2007 & 350 & 366000 & 6 & 15 & 90 \\
\hline Lonza biologics- Tuas, Singapore & 2009 & 250 & na & 4 & 20 & 80 \\
\hline Genentech expansion- Vacaville, CA, USA & 2009 & 600 & 380000 & 8 & 25 & 200 \\
\hline
\end{tabular}

From the reported costs in Table 4.1, it is possible to derive benchmark investment costs relative to bioreactor capacity of $\$ 250,000-\$ 500,000$ per 1000 - liter. This data, as Farid notes (2006), is a ball-park figure with certain limitations. It is not always clear whether the reported costs include indirect expenses such as warehouses, support facilities and office areas and 
validation. For a baseline, a plant with 200,000 L production bioreactor capacity was modeled at $\$ 600 \mathrm{M}$, or the original price of Genentech's expansion plant (CCPII). Two alternative scenarios exists which would either increase or decrease the cost of the facility. In one scenario, purchasing of idle capacity would significantly reduce the capital cost, potentially at a cost next to nothing, or donation. This scenario is realistic due to tax incentives of donating idle capacity. The cost of retro-fitting a facility that was acquired via donation would be significantly lower than the original purchase price. For this scenario, the total cost of the plant was modeled at $\$ 100 \mathrm{M}$. In the second scenario, such as building an entirely new plant, would have a cost higher than the 2009 price due to inflation and rising costs for bio-manufacturing construction. For this scenario, the fixed costs were modeled as $\$ 1000 \mathrm{M}$.

\subsubsection{COGM}

Another critical factor for model calibration is the cost of goods manufactured (COGM). COGM is a function of the facility size and efficiency of the process, which includes all relevant variable and fixed costs associate with production. Commercial antibody manufacture in the $250 \mathrm{~kg} /$ year scale produces drug substance (not vialed), around $\$ 100-\$ 300$ per gram (Kelly 2009). Other studies indicate that processes employing larger scales would reduce COGM down to potentially $\$ 20 /$ gram (Kelly 2007; Werner et al. 2004). This estimate is low compared to actual costs of commercial antibody production for a number of reasons. First, vialing adds a substantial portion of costs, between $\$ 25-\$ 250 /$ gram, depending on the final product configuration. Second, quality systems, distribution and supply chain costs, and the cost of auxiliary operational functions are not included in these cost estimates. Further issues that complicate cost comparisons are whether the COGM values quoted in publicly available 
documents include formulation steps, and whether they are for single-product dedicated facilities or for multi-product facilities. It is difficult to accurately assess these costs and out of scope of this work. To simplify cost benchmarking for the base-case of this model, which utilizes $200,000 \mathrm{~L}$ of capacity and a titer of $1 \mathrm{gm} / \mathrm{L}$, a conservative estimate of $\$ 200 / \mathrm{g}$ was adopted.

\subsubsection{Base-case assumptions}

COGM and capital cost metrics were used to generate a model with known production outputs.

These processes fixed costs for labor, QA/QC tests, raw materials, and consumables for all subsequent models. This baseline facility was then manipulated to simulate a TGE process. The resulting TGE process maintained a number of assumptions for the base-case, which are summarized in Table 4.2. These include: (1) The mAb product is secreted by suspension adapted CHO cells which are grown in 25,000-L stainless steel, stirred tank bioreactors; (2) Production bioreactor operations include a 9 day fermentation, one day of to harvest and a two day turn-around time. This process ranges in volumetric productivity from $50-2000 \mathrm{mg} / \mathrm{L}$; (3) Downstream yields aggregate to a $73 \%$ yield and are never the bottleneck during operation, i.e. there are assumed multiple purification trains if necessary; (4) The annual up-time for the plant is 3 months /year with a 95\% utilization rate; (5) Fixed costs for the 200,000 -L capacity are $\$ 600$ million, depreciation was either included using a straight line method, or excluded; (6) There is a $5 \%$ overall process failure rate; (7) The specific growth rate $(\mu)$ for $\mathrm{CHO}$ is 18 hours, which has been experimentally validated (data not shown); (8) Cost of DNA is $\$ 377 /$ gram and is always available on demand (see chapter 5 for details); (9) PEI is $\$ 30 /$ gram and always available. 


\begin{tabular}{cc}
\hline Table 4.2. Base-case assumptions \\
\hline Production System & $\begin{array}{c}\mathrm{CHO} \text { in stirred tank } \\
\text { bioreactors }\end{array}$ \\
$\begin{array}{c}\text { Bioreactor } \\
\text { Fermentation } \\
\text { Bioreactor Harvest } \\
\text { Bioreactor Turn- } \\
\text { around }\end{array}$ & 9 days \\
$\begin{array}{c}\text { Downstream Yield } \\
\text { Plant Capacity }\end{array}$ & 1 day \\
Failure Rate & 2 days \\
Plant Uptime & $73 \%$ \\
Plant Utilization & $500,000(8 \times 25,000)$ \\
DNA & 3 months \\
PEI & $95 \%$ \\
\hline $\begin{array}{c}\text { Specific Growth Rate } \\
(\mu)\end{array}$ & $\$ 377 /$ gram \\
Fixed Costs $\mathbf{( \$}$ M) & 18 hours \\
\hline
\end{tabular}

\subsubsection{TGE experimental validation}

To refine model parameters, TGE protocols were experimentally validated. Transfections (Chapter 3) were carried out in 3-L bioreactors. Results from these experiments indicate a 9 day, PEI-based TGE process in $\mathrm{CHO}$ yields $304 \mathrm{mg} / \mathrm{L}$ of antibody before purification.

\subsection{Results}

\subsubsection{Base-case}

Simulation using the base-case assumptions, outlined in Table 4.2, produced between 32 to $1,274 \mathrm{~kg}$, with a large dependency of process titer (Table 4.3, Figure 4.3). Within this set of processes, the bio-defense production targets of 12,120 and 1,200 of antibody in 12 weeks were met with titers of 18,190 and $1,840 \mathrm{mg} / \mathrm{L}$, respectively. Production output increased with increases in titer in a linear fashion, while COGM decreased with increases in titer in an inverse 
function. COGM displayed marginal returns at the high end of titers, starting around $500 \mathrm{mg} / \mathrm{L}$ (Figure 4.5). The COGM was close to $\$ 169 /$ gram at the titers that meet the Phase 3 production target of 1,200 kg for countermeasures. The cost of the transfection agents compared to overall cost was always less than $6 \%$. This is in disagreement with previous studies (Backliwal 2008), most likely due to the scales of economies utilized in this study which were not considered by Backliwal.

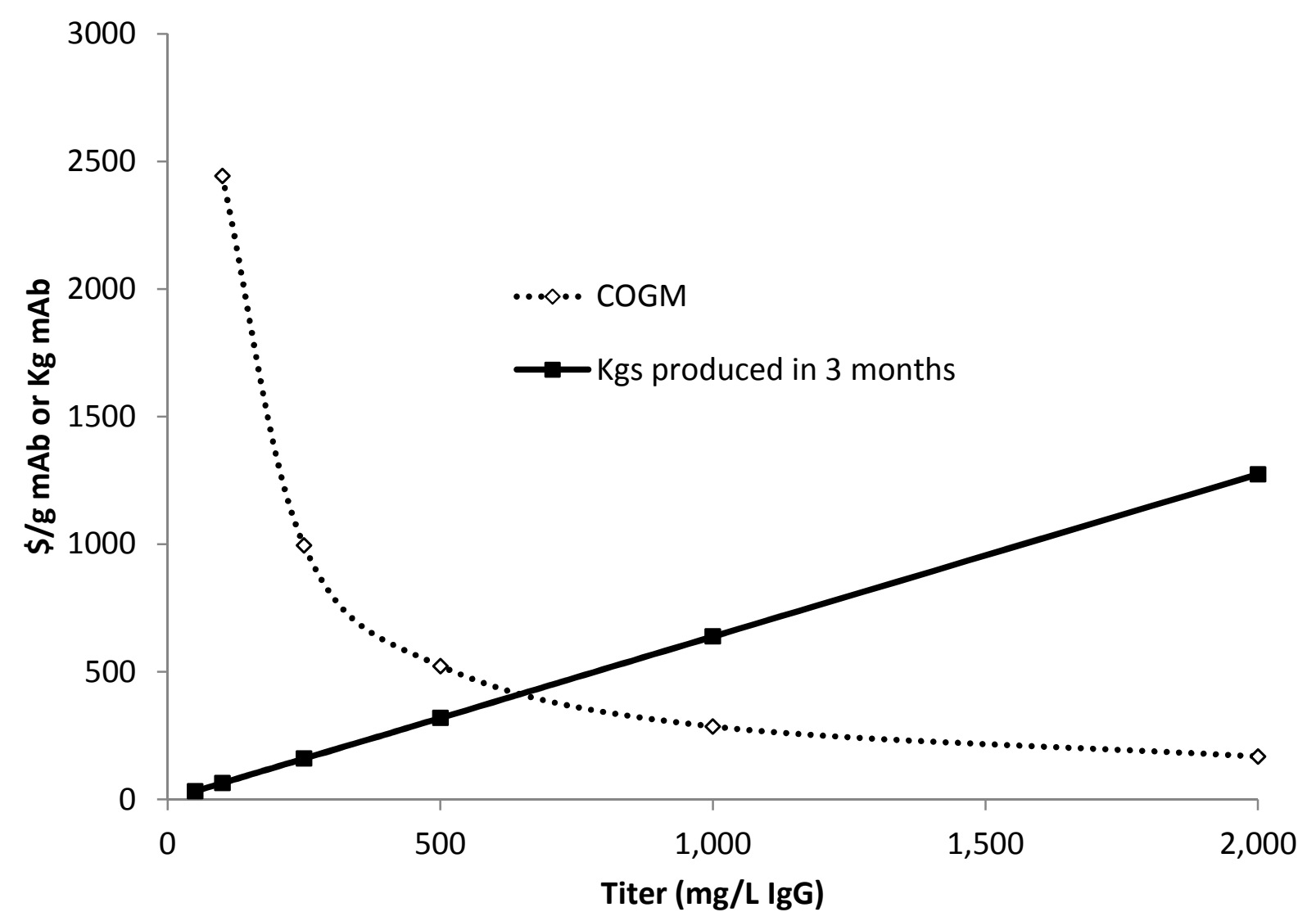

Figure 4.3. Simulation results from base-case model.

Model consisted of 8x 25,000 L reactors operating on a 12 day cycle for 3 months of operation. The process modeled in SuperPro v7.0 software was a PEI-mediated TGE in CHO with a range of titers. 
Table 4.3. Antibody production targets for bio-defense

\begin{tabular}{|cccc|}
\hline Phase & $\begin{array}{c}\text { Antibody } \\
\text { Required } \\
(\mathbf{k g})\end{array}$ & $\begin{array}{c}\text { Titer } \\
\text { Required } \\
(\mathbf{m g} / \mathbf{L})\end{array}$ & $\begin{array}{c}\text { COGM } \\
\text { (\$/gram) }\end{array}$ \\
\hline $\mathbf{1}$ & 12 & 18 & 35710 \\
\hline $\mathbf{2}$ & 120 & 188 & 2733 \\
\hline $\mathbf{3}$ & 1200 & 1883 & 209 \\
\hline
\end{tabular}

\subsubsection{Experimental validation}

In order to corroborate some of the parameters that were used during simulation (Table 4.2), especially titer, $\mathrm{CHO}$ transfections using PEI were conducted in 3-L bioreactors (Chapter 3). Transfections resulted in a titer of $304 \mathrm{mg} / \mathrm{L}$ after 9 days of cultivation. Simulation with these

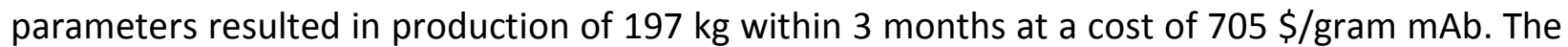
breakdown of associated COGM costs is shown in Figure 4.5. Facility costs dominated COGM, followed by raw materials and labor.

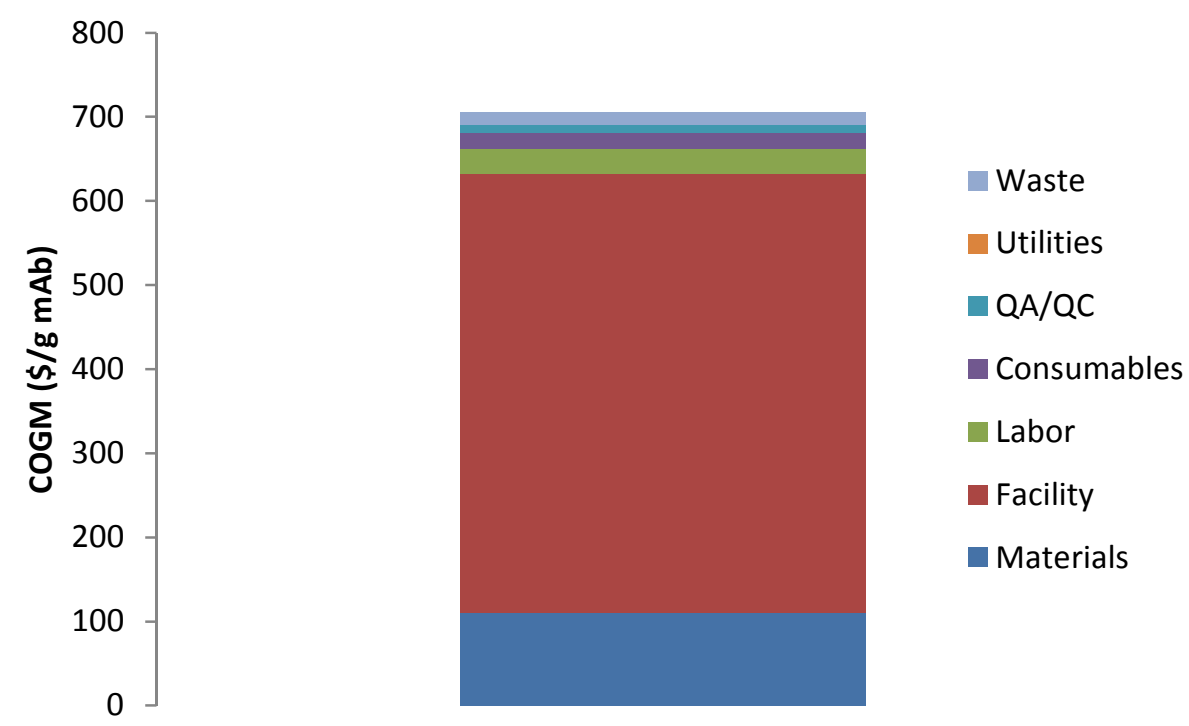

Figure 4.4. COGM break down for $304 \mathrm{mg} / \mathrm{L}$ process.

Model consisted of $8 \times 25,000$ L reactors operating on a 12 day cycle for 3 months of operation. The process modeled in SuperPro v7.0 software was a PEI-mediated TGE in CHO. 


\subsubsection{Scenario analysis}

After simulating a realistic process in a 200,000 L facility, scenario analysis was conducted with various capacity utilization structures and capital costs. As discussed above, the cost of the facility may range from $\$ 100-\$ 1000 \mathrm{M}$. In addition, the facility house equipment able to turn-over and generate multiple products within the same facility, or a multi-product facility. The multi-product facility, as oppose to a dedicated facility, could be run year round, and fixed costs could be distributed amongst all material produced. Because of these possibilities, the experimental model was simulated under various facility structures. These include either 3 months of operation, which would be solely for bio-defense purposes, or a multi-use facility that operates for 12 months out of the year, where the remaining 9 months are used for other products production.

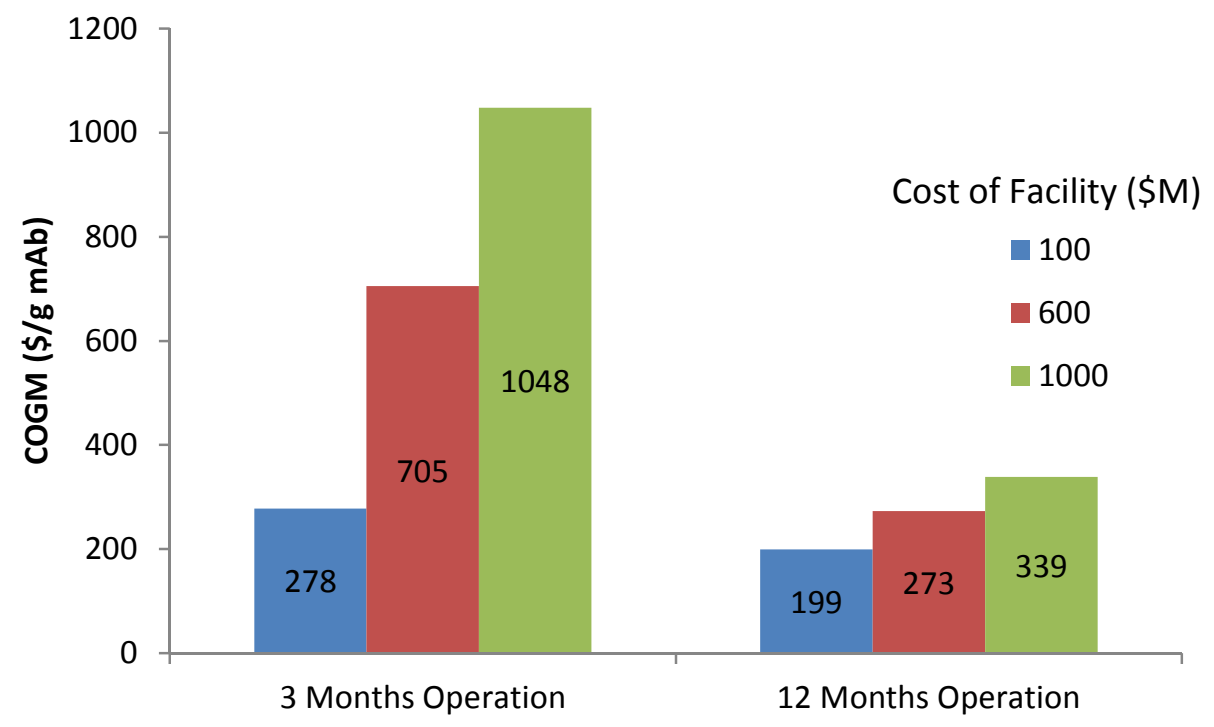

Figure 4.5. COGM under different capital cost structures and utilization scenarios. Model consisted of $8 \times 25,000 \mathrm{~L}$ reactors operating on a 12 day cycle for 3 months of operation. The process modeled in SuperPro v7.0 software was a PEI-mediated TGE in CHO. 
Simulation of the experimental process under various capital cost and utilization structures showed dramatic differences in the cost of antibody production (Figure 4.5). More expensive facilities produce antibodies at a higher cost. Similarly, dedicated facilities produce antibodies at a higher cost compared to a multi-product facility. The use of a multi-product facility, however, had a larger effect on the overall cost of production compared to the capital cost structure. These results suggest utilizing installed capacity through contract manufacturers who have multiple products in production, may be an optimal strategy for bio-defense purposes.

\subsection{Conclusion}

In this study, we aimed to assess the possibility of rapid, large scale production of monoclonal antibodies. A SuperPro model was constructed representing the most up to date methods in antibody production. The model was calibrated based off of published studies and parameters estimation was verified through lab scale experiments. The model predicted that a facility with 200,000-L bioreactor capacity could produce between 32 and 1,274 kg of recombinant protein within 12 weeks of production. Production was highly dependent on process titer. Titer increases had marginal reductions in COGM above $500 \mathrm{mg} / \mathrm{L}$. A scenario analysis of capital costs structures and utilization rates demonstrated a multi-product facility is an optimal strategy for bio-defense production. Future work to enable bio-defense capabilities of rapid monoclonal antibody production should focus on increasing titer and validating the assumptions that a TGE system will scale to $25,000-\mathrm{L}$ bioreactors. In addition, this model was deterministic; a probabilistic one, which utilized a range of values for cost, process times and yields with an 
associate probability density function for those values, would provide more realistic output estimates (Farid 2001; Farid et al. 2008a; Farid et al. 2008b).

\subsection{Appendix}

\section{Detailed description of Unit operations and parameters}

A simplified deterministic model was created to simulate antibody production using TGE systems. The process begins with a series of steps which cells are expanded using progressively larger vessels. Inoculum starts by thawing a tube of frozen cells and using it to inoculate a 500 $\mathrm{ml}$ culture in a shaker flask. The culture is grown for forty two hours (2.3 doublings) then passaged into a disposable bioreactor at a 1:5 concentration split ratio. Similar growth and split ratios are carried on through two disposable bioreactors. There are four identical inoculum suites which are run in staggered mode to maximize throughput. These cultures are passaged into 1000-L stainless steel bioreactor and expanded to a 5000-L stainless steel bioreactor using growth times and split ratios described above. Contents from the 5,000-L reactor were concentrated using microfiltration and diafiltered using a $100 \mathrm{kDa}$ MWCO hollow fiber at a shear rate of $20 \mathrm{~L} / \mathrm{m} 2 \mathrm{hr}$. Filtered culture were then feed into a 25,000-L stainless steel, stirred tank vessel. Transfection complexes consisting of appropriate amounts of DNA and PEI were prepared in an agitated vessel then transferred into the production bioreactor for transfection. $250 \mathrm{~g}$ DNA and $500 \mathrm{~g}$ PEI were added per reactor, and assumed to be on hand, as subsequent analysis will show DNA fermentation and purification not to be rate limiting (Chapter 5). Post transfection production consists of ten days of a fed-batch operation with a bolus feed of 20,000 L of production media four hours post transfection. 
Once fermentation is complete, the culture is pumped into a surge tank in order to free the bioreactor for turn-around. The culture is then passed through a stacked-disk centrifuge and filtered through a $0.45 \mu \mathrm{m}$ dead-end filter into a storage tank. This recovery has a $95 \%$ yield. Passed filtrate is run through a Protein A affinity chromatography column. This step is carried out in four cycles at a loading capacity of $10 \mathrm{~g} / \mathrm{L}$ and a $100 \mathrm{~cm} / \mathrm{min}$ flow. The resin costs $\$ 7000.00$ per liter, can be cycled forty times before having to be replaced, and has a binding capacity of $15 \mathrm{~g} / \mathrm{L}$. The overall yield of this step is $90 \%$.

Elutant is filtered through a $0.45 \mu \mathrm{m}$ dead-end filter into a storage tank then ultrafiltered to concentrate the filtrate 5 fold. There is a $5 \%$ denaturation rate associated with this operation. The retentate is then pumped into a tank containing a mixture of Tri-n-butyl phosphate (TNBP) and Polysorbate 80 (Tween 80), used to chemically inactivate any enveloped viruses found in the stream. This step has a $6 \%$ loss in product. The product is then filtered and loaded onto an anion exchange column, which has a $15 \mathrm{~g} / \mathrm{L}$ capacity $\$ 1,600 / \mathrm{L}$ cost and a 200 $\mathrm{cm} / \mathrm{min}$ linear velocity. The elutant is mixed with ammonium sulfate and then passed over a hydrophobic interaction column (HIC). This column has a $40 \mathrm{~g} / \mathrm{L}$ binding capacity and costs $\$ 3,200$ per liter. Both resins can be cycled 40 times and have an aggregate yield of $90 \%$.

As a final polishing step, the product is passed through a $0.1 \mu \mathrm{m}$ viral exclusion filter. The filter can only be used once, and costs $\$ 27,000$. The product then undergoes a buffer exchange and concentration step using a difiltration unit followed by a final dead end sterile filtration. Five percent of the mAb is denatured during this step. Product is then held in $a$ storage tank until needed. 


\subsection{References}

Abramzon D.; Croughan M. S. A cost-validated model of commercial monoclonal antibody production. Bioprocessing Symposium Presentation, 2007, Amgen Bioprocessing Center, Keck Graduate Institute, Claremont, CA

Backliwal G, Hildinger M,Chenuet S, Wulhfard S, Jesus MD, Wurm FM. Rational vector design an multi-pathway modulation of HEK 293E cells yield recombinant antibody titers exceeding $1 \mathrm{~g} / \mathrm{l}$ by transient transfection under serum-free conditions. Nucleic Acids Research 2008, 36 (15) e96

Backliwal G. Development of High-Titer Transient Gene Expression Processes for Manufacturing Recombinant Proteins. Thesis No 4174. École Polytechnique Federale De Lausanne. 2008

Baldi L.; Hacker D. L.; Adam M.; Wurm F. M. Recombinant protein production by large-scale transient gene expression in mammalian cells: state of the art and future perspectives. Biotechnol. Lett. 2007, 29 (5) 677-84

Belting M.; Sandgren S.; Wittrup A. Nuclear delivery of macromolecules: barriers and carriers. Advanced Drug Delivery Reviews 2005 (57) 505- 27

Birch J.R. and Racher A.J, Antibody Production, Advanced Drugs Discovery Reviews, 2006 (58) $671-85$ 
Carpentier E.; Paris S.; Kamen A. A.; Durocher Y. Limiting factors governing protein expression following polyethylenimine mediated gene transfer in HEK293-EBNA1 cells. J Biotechnol 2007, 128 (2) $268-80$

Casadevall A. Passive antibody administration (immediate immunity) as a specific defense against biological weapons. Emerging Infectious Diseases 2002, 8 (8) 833-41

Defense Advanced Research Projects Agency (DARPA). Accelerated Manufacturing of Pharmaceuticals (AMP). BAA06-31 2006

Farid S. S. A decision-support tool for simulating the process and business perspectives of biopharmaceutical manufacture, Ph.D. Thesis, 2001, University of London.

Farid S.S. Established Bioprocesses for Producing Antibodies as a Basis for Future Planning. Adv. Biochem. Eng. Biotechnol. 2006, (101) 1-42

Ferreira G.M.; Dembecki J.; Patel K.; Arunkumari A. Chromatography: A two-column process to purify antibodies without Protein A. Biopharm International 2007

Fulton S. Proceedings of IBC's Biopharmaceutical Process Economics and Optimization, Washington, DC, September 30-October 11999 
Geisse S. and Fux C. Recombinant protein production by transient gene transfer into mammalian cells. Chapter 15 in Methods in Enzymology 2009, (463) 223-38

Geisse S. Reflections of more than 10 years of TGE approaches. Protein Expression and Purification 2009 (64) 99-107

Hacker D. L.; De Jesus M; Wurm F. M. 25 years of recombinant proteins from reactor-grown cells. Where do we go from here? Biotechnol. Advances 2009 (27) 1023-127

Harrison R.G.; Todd P.; Scott R.R.; Petrides, D.P. Bioseparations Sciences and Engineering; Oxford, New York, 2003 319-69

Heinzle E.; Biwer A.; Cooney C. Development of Sustainable Bioprocesses: Modeling and Assesment, Wiley: West Sussex 2006

Kelly B. Very Large scale monoclonal antibody purification: The case for conventional unit operations. Biotechnol. Prog. 2007 (23) 995-1008

Kodama K.; Katayama Y.; Shoji Y.; Nakashima H. The features and shortcomings for gene delivery of current non-viral carriers. Current Medicinal Chemistry 2006 (13) 2155-61 
Kunath K.; von Harpe A.; Fischer D.; Petersen H.; Bickel U.; Voigt,; Kissel T. Low-molecularweight polyethylenimine as a non-viral vector for DNA delivery: comparison of physicochemical properties, transfection efficiency and in vivo distribution with high-molecular-weight polyethylenimine. J. Cont. Release 2003, 89 (1) 113-25

Levine H. L. A World of Biomanufacturing: Shortages or global glut? BioProcess Int. Conference. Vienna, May, 2010

Rajendra Y.; Kiseljak D.; Baldi L.; Hacker D. L.; Wurm F. M. A simple high-yielding process for transient gene expression in CHO cells. J. Biotechnol. 2011 (153) 22-6

Simpson C. M. Cost modeling for monoclonal antibody manufacturing. Ph.D. Thesis, 2011, Massachusetts Institute of Technology

Sommerfeld S. and Strube J. Challenges in biotechnology production-generic processes and process optimization for monoclonal antibodies. Chem. Eng. Process. 2005 (44) 1123-37

Tarahovsky Y. S. Cell Transfection by DNA-Lipid Complexes - Lipoplexes. Biochemistry (Moscow), 2009, 74 (12) 1293-304 
Tether T. Flexible manufacturing of pharmaceuticals for biological warfare defense. Subcommittee on Defense, Committee on Appropriations, United States House of Representatives. April $24^{\text {th }} \mathbf{2 0 1 0}$

Tuvesson O.; Uhe C.; Rozkov A.; Lüllau E. Development of a generic transient transfection process at $100 \mathrm{~L}$ scale. Cytotechnology 2008 (56) 123-36

Werner R. G. Economic aspects of commercial manufacture of biopharmaceuticals. J. Biotechnol. 2004, 113 (1-3) 171-82

Wurm F. M. and Bernard A. Large-scale transient expression in mammalian cells for recombinant protein production. Curr. Opin. Biotechnol. 1999, 10 (2) 156-9

Wurm F. M. 2004. Production of recombinant protein therapeutics in cultivated mammalian cells. Nat. Biotechnol. 2004, 22 (11) 1393-8 


\title{
CHAPTER 5. PLASMID DNA PRODUCTION FOR LARGE SCALE TRANSIENT GENE EXPRESSION
}

\begin{abstract}
Large scale production of recombinant proteins using transient gene expression requires large scale production of DNA plasmids. In order to evaluate the feasibility of such an approach, a process for very large-scale production of pDNA was designed based upon published literature. A resulting process was simulated and modeled using SuperPro designer 7.0 software. Flow sheets were created and calibrated to experimentally-validated parameters. The model predicted that a 1000-L fermentor and associated purification equipment could produce $29.9 \mathrm{~kg}$ of pDNA in a year at a cost of $\$ 377 /$ gram. This amount of DNA would satisfy the pDNA requirements for large scale transient gene expression, in order to meet bio-defense needs. This capability would also be sufficient for production of pandemic pDNA vaccines or other clinical material.
\end{abstract}

\subsection{Introduction}

Demand for pharmaceutical grade plasmid DNA (pDNA) is expected to rise due to an increasing number of pDNA-products nearing completion of clinical trials as well as a surge of interest in transient gene expression methods (TGE; Geisse 2009; Lou and Saltzman 2000; Rozkov et al. 2008). To satisfy this demand, especially markets where pDNA products will be injected into patients, economically feasible processes suited for manufacturing of gram to kilograms of purified pDNA per batch are needed. These production processes must meet regulatory 
requirements from the authoritative bodies, such as the FDA, EMEA, and WHO (FDA 1996a; WHO 1998; Falk and Ball 2001; Smith 2001).

All polynucledotides are negatively charge under physiological conditions, extremely sensitive to enzymatic hydrolysis, and highly susceptible to size/shape dependent degradation by shear forces (Mairhofer and Grabherr 2008; Anchordoquy and Molina 2007). Plasmids are double-stranded, extra-chromosomal, circular polynucleotides, typically containing 3-20 kilo base pairs (bp), which corresponds to a relative molecular mass of $2 * 10^{6}-13^{*} 10^{6} \mathrm{~g} / \mathrm{mol}$ and a radius of gyration of 100nm and higher (Tyn and Gusek 1990). The supercoiled (sc) or covalently closed circular (ccc) topological pDNA isoform is the most desirable for therapeutic application, as it is considered the most stable (Sinden and Alkek 1994). Other forms are derived from the ccc form by either a single strand nick, resulting in a relaxed form, which is known as nicked or open circular (oc), or double strand nick resulting in linear DNA. Conjugation of plasmids leads to di-, oligo- and multimeric pDNA forms called concatemers and catenanes. (Summers 1996; Martin 1996). For therapeutic application purity is often expressed as a percentage of ccc form compared to the total pDNA (US FDA 1996b). Under current regulations, direct human clinical use requires this ratio to be higher than 90\% (US FDA 1996a; US FDA 1998). Whether or not the DNA is intended for direct human clinical use, or as a process intermediate to make antibodies through TGE, impurities must be kept low, including a low content of genomic DNA (gDNA), RNA, proteins, and endotoxins (Weir 1999; Schleef 1999; Prazeres et al. 1999).

Beyond quality, there are economic aspects, such as yield, productivity and cost of goods that are vital for the success of an industrial manufacturing process. Elimination of bottleneck operations during the various phases is essential. Therefore simple, scalable 
operations should only be considered as well as the avoidance of critical reagents such as animal derived compounds, detergents, and organic solvents.

Plasmids are generally transformed and synthesized in vivo

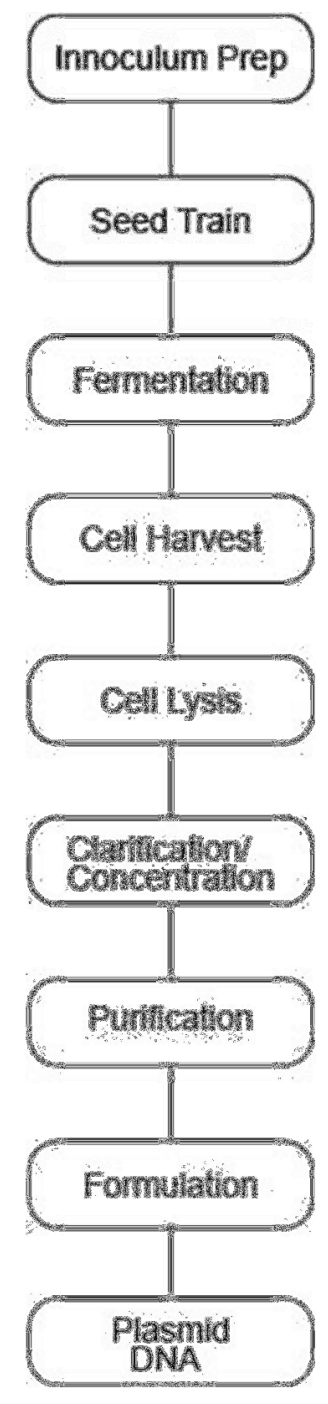

Figure 5.1. General plasmid DNA production process. by the bacterium Esherichia coli (E. coli; Prather-Jones et al. 2003). pDNA production processes typical begin with seed train operations which culminate in a production-scale fermentation step, which is followed by a sequence of downstream processing operations (Figure 5.1). At the laboratory scale, production and purification of plasmids are generally viewed as relatively easy and simple procedures. However, plasmid production under laboratory conditions (non-optimized), generally leads to low volumetric titers (Prazeres 2011). There has been increasing interest for larger, more productive processes which now routinely achieve productivity levels in the gram/liter scale (Varley et al. 1999; Diogo et al. 2001; Lander et al. 2002; Listner et al. 2006). Many of these advances have come from investigations into strain development (Bower et al. 2009; Cunningham et al. 2009), fermentation processes (Silva et al. 2009; Rozkov et al. 2006; Huber et al. 2005; Carnes et al. 2006; William et al. 2009b), purification strategies (Urthaler et al. 2005; Schmidt et al. 2003; Diogo et al. 2005) and economic scale-up (Hewitt and Nienow 2007; Onyeaka et al. 2003). Many of these processes, however, utilize unit operations that either do not scale 
or will not meet appropriate regulatory guidelines. These include precipitation and extraction using organic solvents, RNA reduction using animal-derived RNase, and purification using density gradients or other means that employ toxic reagents such as $\mathrm{CsCl}$, phenols or $\mathrm{CsBr}$ (Levy et al. 2000; Shamlou 2003; Kahn et al. 2000; Eon-Duval and Burke 2004). There have also been a number of economic and environmental impact analyses of pDNA production (Freitas et al. 2006; Cliffe 2010; Hoare et al. 2005; Prazeres and Ferreira 2004), with some studies specifically addressing pDNA production for TGE (Wight 2001; Schmid et al. 2001; Rozkov et al. 2008; Cheng et al. 2011). Reported processes and their subsequent analyses, however, fail to provide meaningful predictions regarding current capabilities for two reasons. First, they do not take into account the most recent advances in pDNA production technology, and they do not address the market for large scale TGE. Therefore, the goal of this study is to estimate cost and time parameters involved in very-large-scale production of pDNA for transient transfection.

\subsection{Model case}

The process utilized in this analysis was configured through a generalized upstream fermentation stage, and a detailed downstream purification stage. The unit operations are shown in Figure 5.1 and were modeled using SuperPro Designer Software version 7.0.

Fermentation processes were based off of an aggregate of current methods summarized in Table 5.1. Briefly, an inoculum preparation begins with thawing a tube of frozen E. coli cells. Cells are transformed with appropriate plasmid construct which contain the gene of interest, selectable marker, and origin of replication. The initial DNA construct would be chemically synthesized by traditional methods (Mullis and Faloona 2003; Stemmer et al. 1995). Bacteria 
are expanded from shaker flasks to a $10-\mathrm{L}$ working volume stainless steel reactor. Cell mass is cultivated until sufficient quantity is generated. Culture is transferred to a $1000-\mathrm{L}$ stainless steel fermentation vessel where fermentation is carried out. Plasmid production is induced through the addition of supplements and the use of temperature shifts (Williams et al. 2009b). The final cell concentration or Dry Cell Weight (DCW) and the specific yield of the production fermentor are critical output from this set of unit operations. The culture is then stored in a surge tank and purification begins.

The downstream operations, or purification of plasmid DNA, were based off of an industrial scale process developed by Urthaler et al. (2005). The process is generic and scalable and has been used to purify pDNA from 200 to 4000-L fermentations (Urthaler et al. 2005). The process fulfills regulatory requirements and delivers pharmaceutical-grade pDNA, which is up to $98 \%$ ccc. The final genomic DNA content is lower than $10 \mu \mathrm{g} / \mathrm{mg}$ plasmid DNA and endotoxin content lower than $0.1 \mathrm{EU} / \mathrm{mg}$ plasmid DNA. The process described here utilized a $1000-\mathrm{L}$ fermentation tank and equipment sized to handle purification of subsequent material accordingly.

The entire flow sheet for pDNA production is shown in Figure 5.2. The process consists of inoculum preparation, seed train expansion, production scale fermentation, primary recovery, gentle lysis and clarification, conditioning, three chromatographic steps, and a final filtration/ formulation step, as listed in the generalized process (Figure 5.1). 


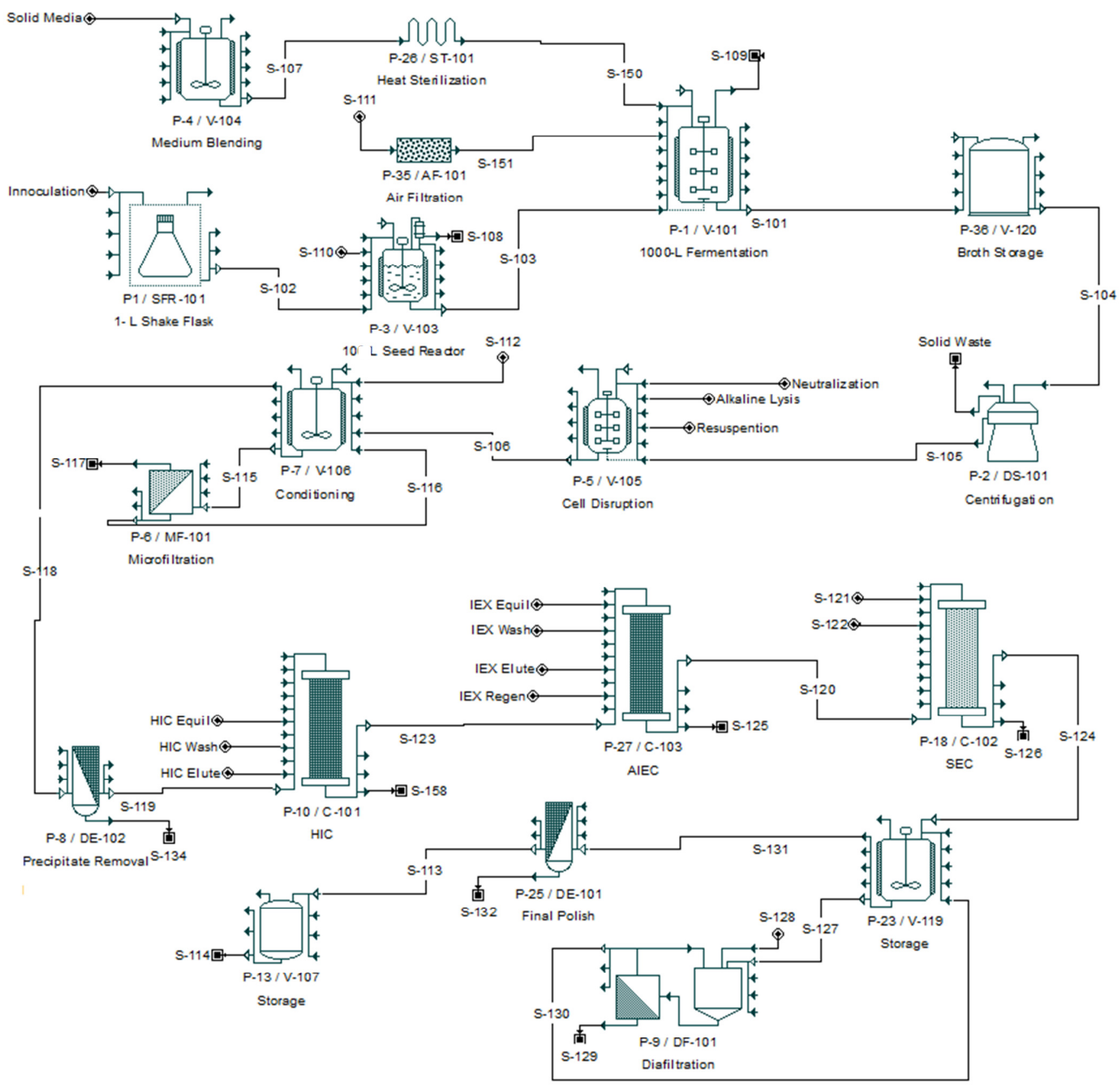

Figure 5.2. Plasmid production and purification flow sheet.

Fed-batch, temperature induced plasmid production with E. coli in 1000-L stirred tank fermentors was modeled using SuperPro Designer v7. 


\subsection{Model calibration}

In order to calibrate the base-case to fit realistic material flows, an overview of hightiter plasmid fermentation processes was prepared and examined (Table 5.1). Four fermentation output parameters were compared among key references. For the base-case scenario, the averages of these output parameters were used. These fermentations rely on nutrient-limited, fed-batch processes with plasmid induction systems to achieve high titers. The use of multiple sources and averaging their values provides a better estimate how current technology would apply to a new manufacturing organization. Some of the key parameters involved were the final cell density, measured either by an optical density (OD as measured at $600 \mathrm{~nm}$ ) and/or a dry-cell weight (DCW), the final volumetric productivity, and the specific yield. When not specified in the reference, a final DCW was calculated from the published OD and the common ratio of $0.4 \mathrm{~g} / \mathrm{L} \mathrm{DCW}$ per 1 unit OD (Pranther et al. 2003). The average final DCW used in the base-case model was $42.7 \mathrm{~g} / \mathrm{L}$ and the average plasmid yield was $37.8 \mathrm{mg}$ pDNA/ g DCW.

Table 5.1. Fermentation overview

\begin{tabular}{|c|c|c|c|c|}
\hline Final Cell OD & $\begin{array}{c}\text { Final Volumetric } \\
\text { Productivity } \\
\text { (mg/L) }\end{array}$ & $\begin{array}{l}\text { Final dry-cell } \\
\text { weight }(\mathrm{g} / \mathrm{I})^{*}\end{array}$ & $\begin{array}{l}\text { pDNA yield } \\
\text { (mg/g dry cell } \\
\text { weight) }\end{array}$ & Reference \\
\hline 90 & 1600 & 36 & 39 & Listner et al. 2006 \\
\hline 88 & 2200 & 35.2 & 62.5 & Carnes et al. 2010 \\
\hline 115 & 2590 & 46 & 56.30 & Carnes et al. 2010 \\
\hline 84 & 1210 & 33.6 & 36.01 & Williams et al. 2009a \\
\hline 97 & 1070 & 38.8 & 27.58 & Carnes et al. 2006 \\
\hline 86 & 595 & 34.4 & 17.30 & Singer et al. 2009 \\
\hline 187 & 1923 & 74.8 & 25.71 & Phue et al. 2008 \\
\hline $106.7 \pm 36.9$ & $1598 \pm 694$ & $42.7 \pm 14.8$ & $37.8 \pm 16.5$ & $\begin{array}{c}\text { Average } \pm \text { standard } \\
\text { deviation }\end{array}$ \\
\hline
\end{tabular}


*Cell density was estimated based on an OD600 of 1 being equivalent to $0.4 \mathrm{~g} / \mathrm{l} \mathrm{DCW}$.

Calibration of downstream material flows were based off of the detailed work by Urthaler et al. (2005), who rigorously characterized this purification regime. The overall yield of the process is $65 \%$ and provides $96 \%$ pure plasmid DNA at a final concentration of $3.3 \mathrm{mg}$ pDNA/ml in a Tris-EDTA buffer (TE) (Table 5.2).

Table 5.2. Downstream key assumptions

\begin{tabular}{lcccccc}
\hline \multicolumn{1}{c}{ Process Step } & Yield & & $\begin{array}{c}\text { Recovery } \\
\text { (\%) }\end{array}$ & $\begin{array}{c}\text { Homogeneity } \\
\text { (\% ccc) }\end{array}$ & $\begin{array}{c}\text { Purity } \\
\text { (\%) }\end{array}$ & $\begin{array}{c}\text { Pool-Concentration } \\
\text { (ug ccc / ml) }\end{array}$ \\
\hline Lysis & 86 & 86 & - & 87 & 3 & 41 \\
Conditioning & 97 & 83 & 95 & 92 & 28 & 122 \\
HIC & 87 & 72 & 86 & 87 & 79 & 211 \\
AIEC & 94 & 68 & 99 & 97 & 92 & 615 \\
SEC & 103 & 70 & 101 & 97 & 97 & 461 \\
Ajustm. Of conc. & 93 & 65 & 95 & 96 & 96 & 3297 \\
Drug Substance & 99 & 65 & - & 96 & 96 & 3294 \\
\hline
\end{tabular}

Adapted from Urthaler et al. 2005

Other key assumptions involved in model development were an uptime of 90 days per year with a capacity utilization of $95 \%, 1000-\mathrm{L}$ production fermentor, and a $5 \%$ process failure rate (Table 5.3). Greater detail for each unit operation can be found in the Appendix. 


\begin{tabular}{ll}
\hline Table 5.3. Base-case assumptions & \\
\hline $\begin{array}{l}\text { Production System } \\
\text { Product }\end{array}$ & E. coli in stirred tank fermentor \\
$\begin{array}{l}\text { Working volume of pDNA production } \\
\text { bioreactor }\end{array}$ & $1,000 \mathrm{~L}$ \\
\hline Upstream & 2 day fermentation, 12 hour harvest, 1 day turn-around \\
\hline Biomass Yield & $42.7 \mathrm{~g} / \mathrm{L} \mathrm{DCW}$ \\
\hline pDNA Yield & $37.8 \mathrm{mg} / \mathrm{g} \mathrm{DCW}$ \\
\hline Annual plant up-time & $90 \mathrm{days}$ \\
\hline Final Product Configuration & $3.3 \mathrm{mg} / \mathrm{ml} \mathrm{pDNA} \mathrm{in} \mathrm{TE} \mathrm{Buffer}$ \\
\hline Downstream Process Yield & $65 \%$ \\
\hline Process Failure Rate & $5 \%$ \\
\hline
\end{tabular}

\subsection{Results}

\subsubsection{Economic overview}

Table 5.4 shows the key economic evaluation parameters. For a plant of this capacity, the total capital investment is around $\$ 17.6$ million. The plant would be capable of producing $29.9 \mathrm{~kg}$ of pDNA within 3 months at a cost of goods manufactured (COGM) of $\$ 377 /$ gram. This COGM compares to other studies (Freitas et al. 2006) which found a unit cost near $\$ 500 /$ gram pDNA for $23.2 \mathrm{Kg}$ produced/year. Cost differences between these studies were due to greater scale of economies from both larger equipment and batch sizes, higher efficiencies in unit operations and shorter batch times. 
Table 5.4. Economic results overview

\begin{tabular}{|c|c|}
\hline Total Capital Investment & $\$ 17,600,000$ \\
\hline Operating Cost & $\$ 11,300,000 / 3$ months \\
\hline Production Rate & $29,900 \mathrm{~g} / 3$ months \\
\hline Unit Production Cost & $\$ 377 /$ gram \\
\hline
\end{tabular}

The total equipment cost was estimated to be $\$ 18.6$ million, which includes a $20 \%$ buffer for unlisted equipment, such as inoculum preparation supplies. For a full list of equipment and consumable requirements, see Appendix Table 5.1 and 5.2 representatively. A breakdown of COGM is shown in Figure 5.3. The primary cost driver is Facilities (43\%) followed by labor $(20 \%)$ consumables $(17 \%)$ and raw materials (11\%). Laboratory QA/QC costs were low (>5\%). QA/QC costs were calculated as a linear function of labor, which may not include all relevant $Q A / Q C$ costs involved. A more detailed investigation was out of scope for this study due to the complexities of regulatory and firm specific quality costs.

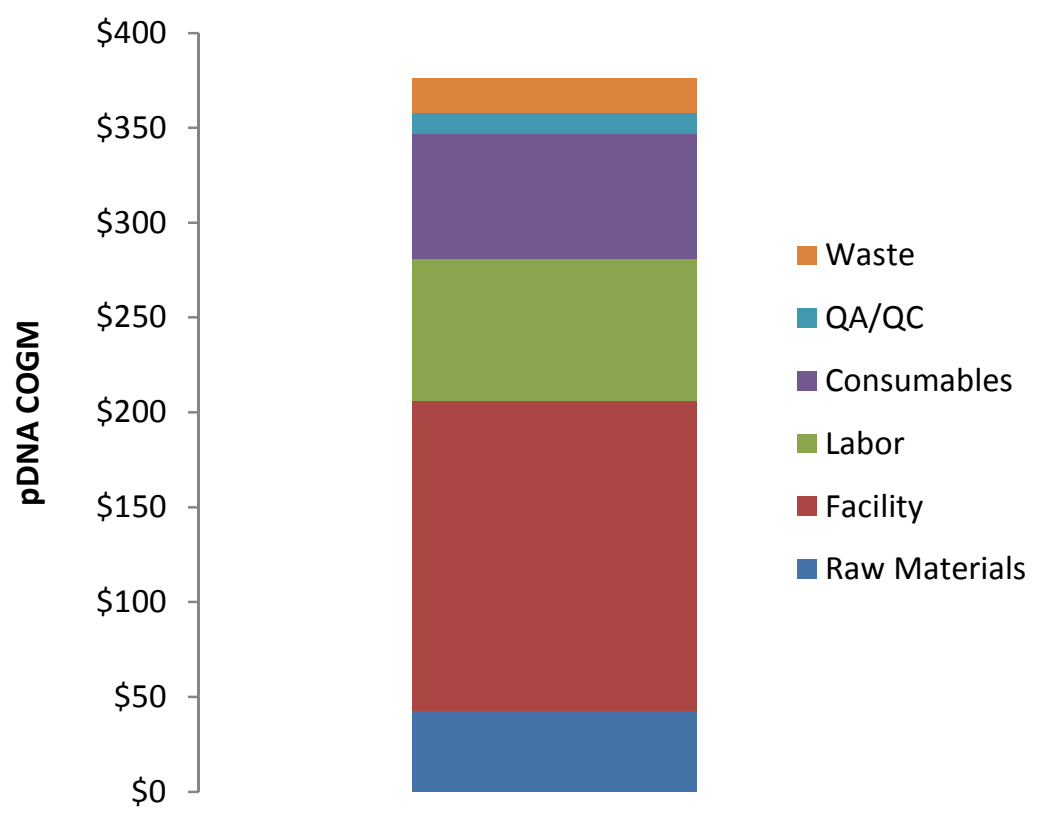


Figure 5.3. Cost break down per gram of pDNA.

\subsubsection{Capacity planning for pDNA production}

In order to determine the appropriate size production facility, production equipment was calculated based on requirements from TGE cell culture. Figure $\mathbf{5 . 4}$ shows the process flow diagram for TGE. Purified pDNA plasmid, produced in the E. coli plant, is used to transfect $\mathrm{CHO}$ cells in a cell culture facility. To determine the amount of pDNA needed for cell culture transfections, the following assumptions were made:

The harvest volume from each of the cell culture bioreactor is 25,000 liters. There are assumed 8 bioreactors for a total cell culture capacity of 200,000 L. Cycle times for cell culture bioreactors is 12 days. Therefore a tank is ready for transfection every 1.5 days, or $4-5$ batches per week. Each 25,000 L bioreactor requires 250 grams per run. A conservative target production rate for purified pDNA form E. coli is between 1 and $2 \mathrm{~kg}$ per week, or $12-24 \mathrm{~kg}$ for the three month window of operation.

Complete utilization of the plant generates over $29.9 \mathrm{Kg}$ of pDNA per year. Each batch of pDNA from the 1000-L process generates $1.15 \mathrm{~kg}$ of material. The first batch of pDNA material is released in 140 hours, and a new batch is released every 74 hours thereafter (Figure 5.5). A smaller sized fermentor, possibly 500-L, may be able to fulfill the low end needs of a cell culture transfection, but both industry's experience with and installed capacity of 1000-L scale fermentors support the use of the larger size vessel. 


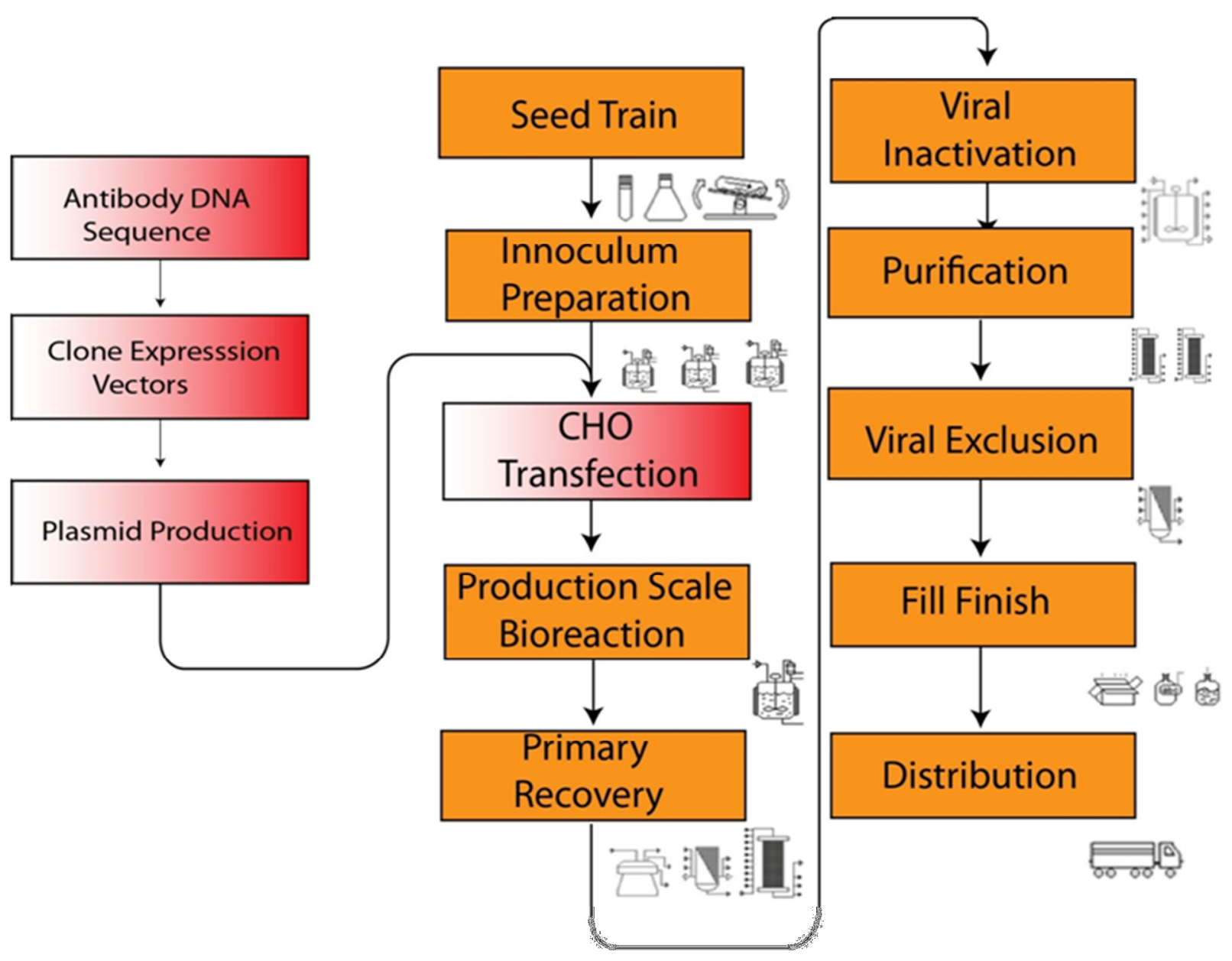

Figure 5.4. General process diagram for TGE. 


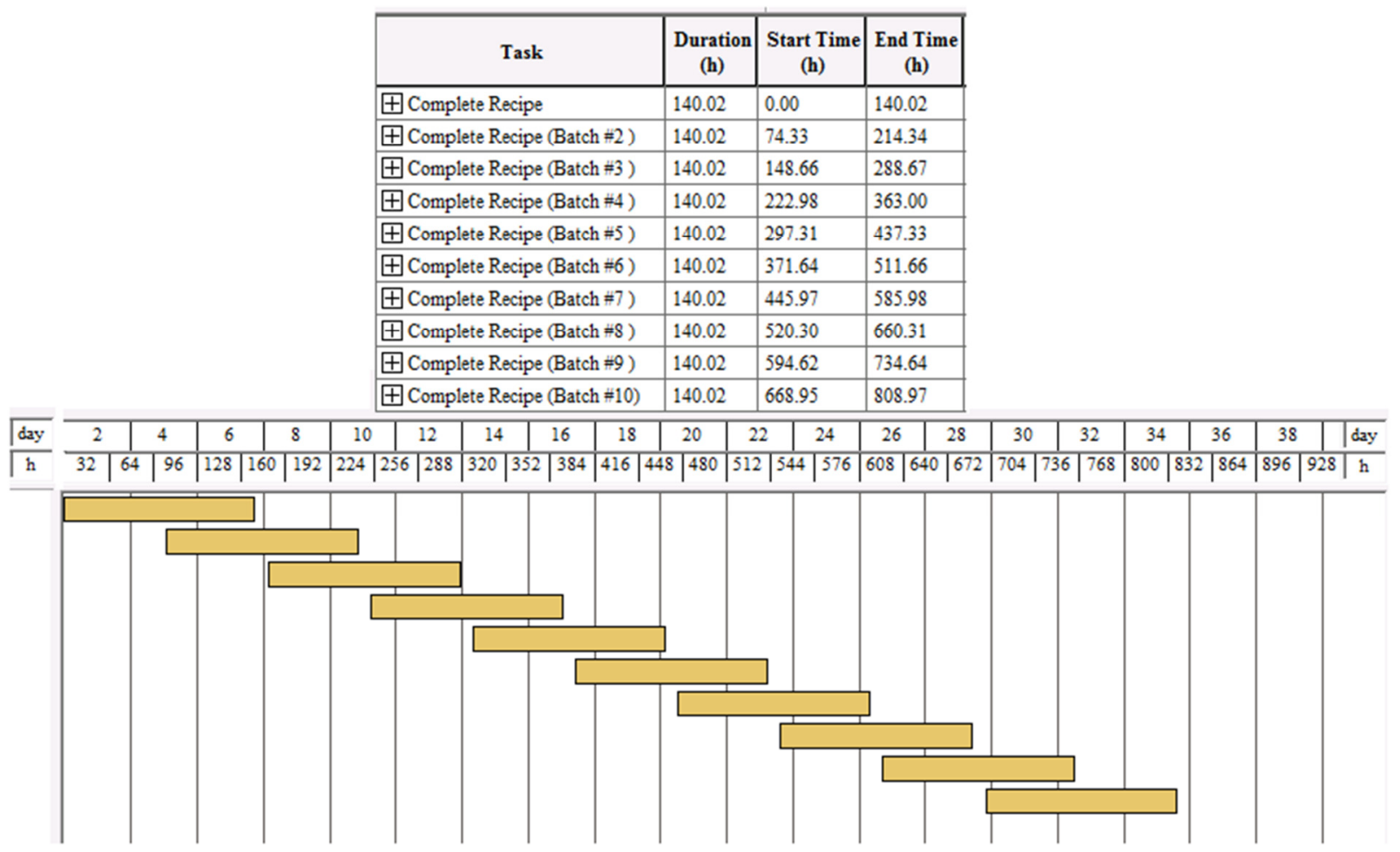

Figure 5.5. Project timeline for multiple pDNA production batches.

\subsubsection{Sensitivity analysis regarding pDNA production}

Due to the inherent variability of biological processes, it was necessary to investigate the multiple scenarios where the pDNA production process may not work as expected. Four critical areas were identified as major points of variability. Biomass generation, pDNA specific yield, primary recovery, and purification were investigated for their effects on the pDNA production process. The yield or productivity of each area was decreased by 5,15 or $45 \%$ and the output effects on COGM and annual yield were observed compared to the base-case (Figure 5.6). Small changes in any parameter did not affect the overall process in terms of COGM or pDNA production. However, larger changes in operations resulted in a much less 
productive process. There was a trend that the closer the unit operation is to the final drug substance, the more dramatic the effect on the entire process (i.e. Purification> Recovery> Specific Yield > Biomass). As the concentration of the final product was more concentrated in each successive step, the dramatic effects observed in downstream operations were expected.
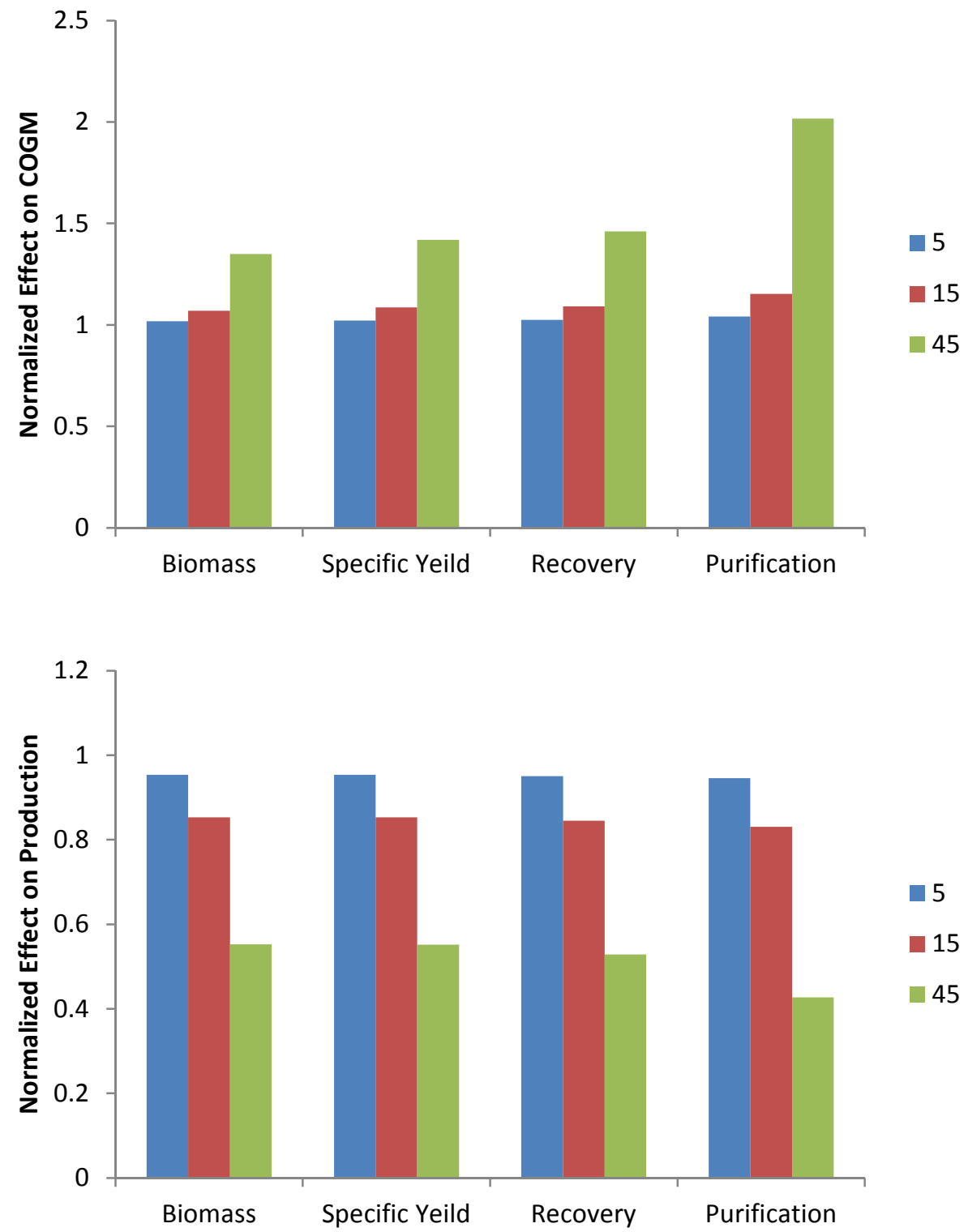

Figure 5.6. Sensitivity analysis on pDNA production processes.

Each unit operation in a scenario was decreased by $5 \%$ (blue), $15 \%$ (red) or $45 \%$ (green) then productivity (kg/year) and COGS (\$/gram) were compared against the base-case model. 


\subsection{Conclusion}

In this study, we aimed to assess the potential of large scale plasmid production. A SuperPro model was constructed representing the most up to date methods in plasmid production. The model predicted that a 1000-L fermentor and associated purification equipment could produce over $29.9 \mathrm{~kg}$ of pDNA in a year at a cost of $\$ 377 /$ gram. This amount of DNA would satisfy the pDNA requirements for large scale TGE, or for use in pandemic pDNA vaccines. Bio-defense interest groups could purchase and operate such a facility, or capacity could be purchased as needed in the event of a mass casualty event. While these results are based off of published studies, there may be a number of problems associated with implementing this process. Freedom to operate is a significant concern, as many aspects of the process technology are patented (Carnes and William 2007; Bulter et al. 2001; Thatcher et al. 1999; Schmidt et al. 2003; Kristyanne et al. 2003; Huber et al. 2005). In addition, this model was calibrated off of studies that utilize model systems with fully optimized plasmids and host organisms. These studies have benefited from a plethora of process development, and, as often is the case in the literature, only the best results are shown. Learning costs associated with achieving manufacturing success may be significant. Moreover, there is significant plasmid specific variability. Molecular biology approaches, such as origin of replication, codon optimization, and size matching, may provide methods to reduce this variability; however, plasmid production differences have been observed (Prazeres 2011). Last, this model was deterministic with single values for parameters; a probabilistic one with a statistical range of 
values would provide more realistic material flow estimates (Farid 2007; Farid et al. 2005a; Farid et al. 2005b)

\subsection{Appendix}

\subsubsection{Unit operation details}

\subsubsection{Inoculum preparation}

Inoculum preparation begins with thawing a tube of frozen E. coli cells, typically DH1, DH5 $\alpha$, or K12. Cells are transformed with appropriate plasmid construct harboring a selectable marker (P1). Initial DNA construct is assumed to be ready on hand $(\sim 1 \mu \mathrm{g})$, which is assumed to be chemically synthesized by traditional methods (Mullis and Faloona 2003; Stemmer et al. 1995). Bacteria are expanded using simple seed train medium to achieve progressively larger fermentation volumes. Transformation operations and expansion up to 1-L culture volumes take 20 hours in total.

1-L inoculum is transferred to a $10-\mathrm{L}$ working volume stainless steel reactor (P-3). Disposable bioreactors have been investigated for microbial fermentations (Galliher 2008; Gaugler et al. 2002; Oosterhuis and van den Berg 2011); however heat and oxygen limitations exist on current disposable configurations. Stainless steel bioreactors are therefore implemented. Simple media is used for this expansion step. Total time for this operation is 24 hours.

Fermentation is carried out using fed-catch protocols. Seed train is diluted 100x with prepared fermentation media in a 1000-L stainless steel fermentation vessel (P-1). Aerobic cultivation of the cells is sustained at all times by adjusting airflow (P-35), agitation rate, and 
back pressure in the reactor. Temperature is maintained at $37^{\circ} \mathrm{C}$ and $\mathrm{pH}$ at $7.1 \pm 0.1$ by addition of ammonium hydroxide. After sufficient biomass accumulation, temperature is shifted to $42^{\circ} \mathrm{C}$. Growth continues for one additional doubling with the addition of supplemented fed-batch media. The total time for this operation is 48 hours, with 40 hours of growth and 8 of posttemperature induction. Final concentration of cells in the fermentor is $43 \mathrm{~g} / \mathrm{L}$ (dry cell weight, DCW). At the end of fermentation, the broth is transferred to a storage vessel (P-36). Seed train and production vessel are both cleaned and sanitized with high pressure steam in order to prepare for the next batch lasting 24 hours.

\subsubsection{Recovery}

Cells are harvested in a disk stack centrifuge (P-2) with 95\% recovery over 12 hours. The broth is concentrated 20 fold from 1000-L to 50-L. Subsequent lysis of E. coli cells are carried out using a modified version of previously reported methods (Ciccolini et al. 2002; Meacle et al. 2004; Clemson and Kelly 2010). Modifications to this step are especially important due to the potential for pDNA damage from caustic solvents and shear stresses (Lengsfeld and Anchordoquy 2001; Freitas et al. 2007). Briefly, the cell pellet is resuspended to $150 \mathrm{~g} / \mathrm{L}$ cell in resuspension buffer (50 mM Tris-HCl, $10 \mathrm{mM}$ EDTA, $\mathrm{pH}$ 8.0). The mixture is blended in a tank (P5) until a homogenous suspension is obtained, roughly 30 minutes. Subsequent lysis is achieved by one part resuspended pellet, and two parts $150 \mathrm{mM} \mathrm{NaOH}$ with $1 \%$ SDS solution. This solution is mixed with $100 \mathrm{rpm}$ gentle orbital agitation for 10 minutes. The mixture is then neutralized with one part $3 \mathrm{M}$ potassium acetate $\mathrm{pH}$ 5.5. Clarified lysate is collected in a surge tank (P-7), then concentrated using microfiltration on a $100 \mathrm{kDa}$ MWCO hallow fiber membrane 
$(\mathrm{P}-6)$ with a shear rate of $20 \mathrm{~L} / \mathrm{m}^{2} * \mathrm{hr}$. During this process there is a $5 \%$ degradation rate of intact pDNA where there is a 7 fold concentration of the solution. Once lysate is concentrate, addition of ammonium sulfate prepares the solution for binding PDNA on the HIC-column. A stock solution of $4 \mathrm{M}$ ammonium sulfate is used to condition the concentrated lysate, as high concentrations of the salt can precipitate pDNA out of solution and reduce recovery. At this concentration, only proteins and gDNA impurities form aggregates and precipitate out of solution. These particulates are filtered out using dead end filtration (P-8) prior to loading the HIC-column. A $4.5 \mu \mathrm{m}$ filter is used to remove large particles from entering the HIC-column. Membranes with smaller pores result in loss of pDNA and filter fouling. Capacity of the filter was assumed to be $100 \mathrm{~L} / \mathrm{m}^{2}$. The overall conditioning steps lead to $83 \%$ yield with a $95 \%$ recovery.

\subsubsection{Purification}

This section achieves two objectives: to concentrate pDNA and to remove a large portion of impurities. Purification is achieved through the use of three different chromatography steps, each of which employ different separation principles for isolation.

The initial column is a HIC membrane (P-10). Maximal dynamic binding capacity (DBC) for pDNA at a linear velocity of $120 \mathrm{~cm} / \mathrm{h}$ is around $2 \mathrm{~g}$ pDNA/L. This was determined using breakthrough curves. A pDNA recovery of more than 95\%, not including regeneration fractions are typical. Yield was set at $87 \%$ with a $5 \%$ pDNA degradation rate.

As the second chromatography step, AIEC is utilized due to a higher yield with prepurified pDNA solutions compared to other processing steps. Because this process can serve as a concentration step, weak AIEC-CIM adsorbents with a DBC between 5 and $10 \mathrm{~g} p D N A / L$ is 
used (P-27). Loading and wash steps use high linear flow rates, while elution uses a reduced flow rate with a step wise increases in conductivity. This step had a yield greater than $90 \%$ and nearly 10 fold concentration.

The order of column purification was optimized from other protocols, which often start with Anionic exchange chromatography (Cunningham 2009; Varley et al. 1999). These protocols often have lower yields and recoveries, especially if lysate is not conditioned or loading time is delayed due to long cycle times and blocking of the membrane during AIEC operations (Urhaler et al. 2005). High salt concentrations in conditioned lysate may lead to a more stable solution compared to one that has been daifiltered against a AIEC loading buffer.

The final purification step uses size exclusion chromatography (P-18), which allows for further impurity removal and buffer exchange. A sepharose support with a maximum feed volume of $35 \% \mathrm{CV}$ at a velocity of $60 \mathrm{~cm} / \mathrm{h}$. Direct loading of the AIEC elution is carried out. Elution buffer is the final buffer desired in formulation (50 mM Tris- $\mathrm{HCl}, 10 \mathrm{mM}$ EDTA, pH 8.0). Yield for this step is greater than $95 \%$.

\subsubsection{Formulation}

For a higher pDNA concentration in drug substance, concentration by tangential flow filtration is used (P-9). 100kDa membranes result in yields great than $90 \%$ depending on the desired final concentration are achieved. Shear rates of $80 \mathrm{~L} / \mathrm{m}^{2} * \mathrm{hr}$ are use to concentrate up to 10 fold.

Final polishing filtration is a simple $0.22 \mu \mathrm{m}$ depth filter to ensure sterility. Capacity of the filter has been determined to be $100 \mathrm{~L} / \mathrm{m}^{2}$ with flow rates up to $5 \mathrm{~L} / \mathrm{m}^{2 *} \min$. Yields of $95-$ 
$100 \%$ are achieved. Bulk pDNA drug substance is housed in a surge tank before freezing and transport to the cell culture transfection facility.

\subsubsection{Additional results}

Table a5.1. Equipment overview

\begin{tabular}{ccc}
\hline Name & Size $\left(\mathrm{L}, \mathrm{M}^{2}\right.$, or $\left.\mathrm{L} / \mathrm{hr}\right)$ & Purchase/Installation Cost \\
\hline Shake Flask Rack & 1.5 & 15 \\
Fermentor & $1,256.35$ & $2,500,000$ \\
Seed Reactor & 127.21 & $2,223,000$ \\
Blending Tank & 1,000 & $1,077,000$ \\
Disk-Stack Centrifuge & $21,306.02$ & 148,000 \\
Clarification Tank & $2,555.38$ & $4,143,000$ \\
Blending Tank & $2,242.82$ & 402,000 \\
HIC Column & 187.06 & 732,000 \\
AlEC Column & 65.1 & 519,000 \\
SEC Column & 524.1 & $1,749,000$ \\
Blending Tank & 3693.77 & 431,000 \\
Dead-End Filter & 4.59 & 47,000 \\
Heat Sterilizer & 900 & 219,000 \\
Air Filter & $30,152.32$ & 7,000 \\
Flat Bottom Tank & $1,114.73$ & 177,000 \\
Microfilter & 28.84 & 137,000 \\
Dead-End Filter & 1.2 & 23,000 \\
Daifilter & 71.07 & 242,000 \\
Receiver Tank & 333.55 & 94,000 \\
\hline
\end{tabular}

Table a5.2. Consumable overview

\begin{tabular}{ccc}
\hline Consumable & $\begin{array}{c}\text { Unit Cost } \\
\left.\text { (item, } \mathrm{M}^{2} \text { or } \mathrm{L}\right)\end{array}$ & Annual Amount \\
\hline 500 ml Shake Flask & 1.7 & 858 \\
$0.2 \mu \mathrm{m}$ Diafilter & 1,000 & 286 \\
$0.1 \mu \mathrm{m}$ Polishing Filter & 400 & 82 \\
$4 \mu \mathrm{m}$ Dead-End Filter & 15 & 343 \\
HIC Resin & 1,500 & 5,350 \\
AlEC Resin & 2,000 & 1,862 \\
Gel Filtration Resin & 800 & 11,242 \\
100 kDa MWCO Hollow & 800 & 825 \\
Fiber membrane & & \\
\hline
\end{tabular}




\subsection{References}

Anchordoquy T. J. and Molina M. C. Frontiers in clinical research Preservation of DNA. Cell Preservation Technol. 2007, 5 (4) 180-8

Backliwal G, Hildinger M,Chenuet S, Wulhfard S, Jesus MD, Wurm FM. Rational vector design an multi-pathway modulation of HEK 293E cells yield recombinant antibody titers exceeding $1 \mathrm{~g} / \mathrm{l}$ by transient transfection under serum-free conditions. Nucleic Acids Research 2008, 36 (15) e96

Bower D. M. and Prather K. L. J. Engineering of bacterial strains and vectors for the production of plasmid DNA. Appl. Microbiol. Biotechnol. 2009 (82) 805-13

Bulter M. D.; Cohen D. L.; Kahn D.; Winkler M. E. Purification of plasmid DNA. US Patent $6,313,285$ B1. November $6^{\text {th }} 2001$

Carnes A. E.; Hodgson C. P.; Williams J. A. Industrial scale cGMP purification of pharmaceutical grade plasmid DNA. Chem. Eng. Technol. 2005, 28 (11) 1408-20

Carnes A. E.; Hodgson C. P.; Williams J. A. Inducible Escherichia coli fermentation for increased plasmid DNA production. Biotechnol. Appl. Biochem. 2006, (45) 155-66

Carnes A. E. and Williams J. A. Plasmid DNA Manufacturing Technology. Recent Patents on Biotechnol. 2007, 1 (2) 1-15 
Carnes A. E.; Luke J. M.; Vincent J. M.; Schukar A.; Anderson S.; Hodgson C. P.; Williams J. A. Plasmid DNA fermentation strain and process-specific effects on vector yield, quality, and transgene expression. Biotechnol. \& Bioeng. 2010, 108 (2) 354-63

Cheng L.; Sun X.; Yi X.; Zhang Y. Large-scale plasmid preparation for transient gene expression. Biotechnol. Lett. 2011 (33) 1559-64

Ciccolini L. A.; Shamlou P. A.; Titchener-Hooker N. A mass balance study to assess the extent of contaminant removal achieved in the operations for the primary recovery of plasmid DNA from Escherichia coli cells. Biotechnol. \& Bioeng. 2002, 77 (7) 796-805

Clemson M. and Kelly W. J. 2010. Optimizing alkaline lysis for DNA plasmid recovery. Biotechnol. \& Bioeng. 2010, 37 (3) 235-44

Cliffe F. E. A study of selected environmental issues related to the production of plasmid DNA for application in gene therapy. PhD. Thesis. University of Limerick, Department of Chemical and Environmental Sciences. 2010

Cunningham D. S., Koepsel R. R., Attai M. M., Domach M. M. Factors affecting plasmid production in Escherichia coli from a resource allocation standpoint. Microb. Cell Factories 2009,8 (27) 
Diogo M. M.; Queiroz J. A.; Prazeres D. M. F. Chromatography of plasmid DNA. J. Chromatography A 2005 (1069) 3-22

Diogo M. M.; Ribeiro S. C.; Queiroz J. A.; Monteiro G. A.; Tordo N.; Perrin P.; Prazeres D. M. F. Production, purification and analysis of an experimental DNA vaccine against rabies. J. Gene Med. 2001 (3) 577-84

Eon-Duval A. and Burke G. Purification of pharmaceutical-grade plasmid DNA by anionexchange chromatography in an RNase-free process. J. Chormatogr. B 2004, 804 (2) 327-35.

Falk L.; Ball L. Current status and future trends in vaccine regulation- USA. Vaccine 2001, 19 (113) $1567-72$

Farid S. S.; Washbrook J.; Titchener-Hooker N. J. Combining multiple quantitative and qualitative goals when assessing biomanufacturing strategies under uncertainty. Biotechnol. Prog. 2005a, 21 (4) 1183-91

Farid S. S.; Washbrook J.; Titchener-Hooker N. J. Decision-Support Tool for Assessing Biomanufacturing Strategies under Uncertainty: Stainless Steel versus Disposable Equipment for Clinical Trial Material Preparation. Biotechnol. Prog. 2005a, 21 (2) 486-97 
Farid S. S. Process economics of industrial monoclonal antibody manufacture. J. Chrom. B 2007 (848) 8-18

FDA. Points to consider on plasmid dna vaccines for preventative infectious disease indications. US Food and Drug Administration. Rockville, MD, USA 1996a

FDA. Addendum to the points to consider in human somatic cell and gene therapy, US Food and Drug Administration, Rockville, MD, USA, 1996b

FDA. Guidance for Industry; Guidance for Human Somatic Cell Therapy and Gene Therapy, US Food and Drug Administration, Rockville, MD, USA 1998

Freitas S. S., Santos J. A. L., Prazeres D. M. F. Plasmid DNA in Development of Sustainable Bioprocesses, Heinzle E., Biwer A., Cooney C. John Wiley \& Sons, Ltd. Sussex, England, 2006

Freitas S. S., Azzoni A. R., Santos J. A. L. , Monteiro G. A., Prazeres D. M. F. 2007. On the stability of plasmid DNA vectors during cell culture and purification. Mol. Biotechnol. 2007 (36) 151-8

Galliher P. Achieving high-efficiency production with microbial technology in a single-use bioreactor platform. BioProcess International 2008 2-5 
Gaugler R., Hatab M. H. Disposable bioreactor for culture microorganisms and cells. US Patent $6,432,698$ B1. August $13^{\text {th }} 2002$

Geisse S. and Fux C. Recombinant protein production by transient gene transfer into mammalian cells. Chapter 15 in Methods in Enzymology 2009, (463) 223-38

Geisse S. Reflections of more than 10 years of TGE approaches. Protein Expression and Purification 2009 (64) 99-107

Hoare M.; Levy S.; Bracewell D. G.; Doig S. D.; Kong S.; Titchener-Hooker N.; Ward J. M.; Dunnill P. Bioprocess Engineering Issues That Would Be Faced in Producing a DNA Vaccine at up to 100 m3 Fermentation Scale for an Influenza Pandemic. Biotechnol. Prog. 2005, 21, 1577-92

Hewitt C. J. and Nienow A. W. The scale-up of microbial batch and fed-batch fermentation processes. Adv. Appl. Micro. 2007 (62) 105-35

Huber H.; Weigl G.; Buchinger W. Fed-batch fermentation process and culture medium for the production of plasmid DNA in E. coli on a manufacturing scale. U.S. Patent 0233421 A1 2005

Kahn D. W.; Butler M. D.; Cohen D. L.; Gordon M.; Kahn J. W.; Winkler M. E. Purification of plasmid DNA by tangential flow filtration.Biotechnol. Bioeng. 2000, 69 (1) 101-6 
Kristyanne E.; Candau R.; Seed J. L. Ion exchange method for DNA purification. United States Patent 6,504,021 B2 2003

Lander R. J.; Winters M. A.; Meacle F. J.; Buckland B. C.; Lee A. L. Fractional precipitation of plasmid DNA from lysate by CTAB. Biotech. Bioeng. 2002, 79 (7) 776-84

Listner K.; Bentley L.; Okonkowski J.; Kistler C.; Wnek R.; Caparoni A.; Junker B.; Robinson D.;

Salmon P.; Chartrain M. 2006. Development of a highly productive and scalable plasmid DNA production platform. Biotechnol. Prog. 2006 (22) 1335-45

Lengsfeld C. S. and Anchordoquy T. J. Shear-induced degradation of plasmid DNA. J. Pharma. Sci. 2001, 91 (7) 1581-9

Levy M. S.; O’Kennedy R. D.; Shamlou P. A.; Dunnill P. Biochemical engineering approaches to the challenges of producing pure plasmid DNA. Trends Biotechnol. 2000, 18 (7) 296-305

Lou, D. and Saltzman W. Synthetic DNA delivery systems. Nature Biotechnol. 2000 (18) 33-7

Mairhofer J.; Grabherr R. Rational Vector Design for Efficient Non-viral Gene Delivery: Challenges Facing the Use of Plasmid DNA. Mol. Biotechnol. 2008 39:97-104

Martin R. Gel Electrophoresis: Nucleic Acids, Bios Scientific, London 1996 
Meacle F. J., Lander R., Shamlou P. A., Titchener-Hooker N. Impact of engineering flow conditions on plasmid DNA yield and purity in chemical cell lysis operations. Biotechnol. \& Bioeng. 2004, 87 (3) 293-302

Mullis K. B. and Faloona F. A. Specific synthesis of DNA in vitro via a polymerase-catalyzed chain reaction. Methods in Enzymology 2003, 155 (1987) 335-50

Onyeake H.; Nienow A. W.; Hewitt C. J. Further studies related to the scale-up of high cell density Escherichia coli fed-batch fermentations: the additional effect of a changing microenvironment when using aqueous ammonia to control pH. Biotech. Bioeng. 2003 (84) 47484

Oosterhuis N. M. G. and van den Berg H. J. How multipurpose is a disposable bioreactor? BioPharm International 2011, 24 (3) 51-6

Phue J. N.; Lee S. J.; Trinh L.; Shiloach J. Modified Escherichia coli B (BL21), a superior producer of plasmid DNA compared with Escherichia coli K (DH5alpha). Biotechnol. Bioeng. 2008 (101) 831-36 
Prather-Jones K.; Sagar S.; Murphy J.; Chartrain M. Industrial scale production of plasmid DNA for vaccine and gene therapy: plasmid design, production, and purification. Enzyme Microb. Technol. 2003, 33 (7) 865-83

Prazeres D. M. F.; Ferreira G. N. M.; Monterio G. A.; Cooney C. L.; Cabral J. M. S. Large-scale production of pharmaceutical-grade plasmid DNA for gene therapy: Problems and bottlenecks. Trends Biotechnol. 1999 (17) 169-74

Prazeres D. M. F. and G.N.M. Ferreira. Design of flowsheets for the recovery and purification of plasmids for gene therapy and DNA vaccination. Chemical Engineering and Processing 2004 (42) 615-30

Prazeres D. M. F. Plasmid Biopharmeceuticals: Basics, Applications and Manufacturing. John Wiley \& Sons, Inc. Hoboken, Ney Jersey. 2011

Rozkov A.; Avigonone-Rossa C. A.; Ertl P. F.; Jones P.; O’Kennedy R. D.; Smith J. J.; Dale J. W.; Bushell M. E. Fed batch culture with declining specific growth rate for high-yielding production of a plasmid containing a gene therapy sequence in Escherichia coli DH1. Enzymes and Microb. Technol. 2006, 39 (1) 47-50 
Rozkov A., Larsson B., Gillstrom S., Bjornestedt R., Schmidt S. R. Large-scale production of endotoxin-free plasmids for transient expression in mammalian cell culture. Biotechnol \& Bioeng 2008, 99 (3) 557-66

Schmid G.; Schlaeger E. J.; Wipf B. Non-GMP plasmid production for transient transfection in bioreactors. Cytotechnology 2001 (35) 157-64

Schmidt T.; Friehs K.; Flaschel E.; Schleef M. Method for the isolation of ccc plasmid DNA. US Patent 6,664,078 B1. December $16^{\text {th }} 2003$

Schleef M. in Biotechnology (Eds: Mountain A.; Ney U. M.; Schomburg D.), 5a, Wiley-VCH, Weinheim, 1999

Silva F.; Passarinha L.; Sousa F.; Queiroz J. A.; Domingues F. C. Influence of growth conditions on plasmid DNA production. J. Microbiol. Biotechnol. 2009, 19 (11) 1408-14

Sinden R. R. and Alkek A. B. DNA Structure and Function. Academic Press, San Diego. 1994

Singer A.; Eiteman M A.; Altman E. DNA plasmid production in different host strains of Escherichia coli. J. Ind. Microbiol. Biotechnol. 2009 (36) 521-30 
Shamlou P. A. Scalable processes for the manufacture of therapeutic quantities of plasmid DNA. Biotechnol. Applied Biochem. 2003, 37 (3) 207-18

Smith A. H. and Klinman D. M. 2001. The regulation of DNA vaccines. Curr. Opin. Biotechnol. 2001, 12 (3) 299-303

Stemmer W. P., Crameri A., Ha K. D., Brennan T. M., Heyneker H. L. 1995. Single-step assembly of a gene and entire plasmid from large numbers of oligo-deoxy-ribonucleotides. Gene 1995, 164 (1) 49-53

Summers D. K. The Biology of Plasmids, Blackwell Science Oxford 1996.

Thatcher D. R., Hitchcock A., Hanak J. A. J., Varley D. L. 2003. Method of plasmid DNA production and purification. US Patent 6,503,738 B1. Jan $7^{\text {th }} 2003$

Tyn M.; Gusek T. Prediction of diffusion coefficients of proteins. Biotech. Bioeng. 1990, 35 (5) $327-38$

Urthaler J., Buchinger W., Necina R. Improved downstream process for the production of plasmid DNA for gene therapy. Acta Biochimica Polonica 2005, 52 (3) 703-11

Varley D. L.; Hitchcock A. G.; Weiss A. M. E.; Horler W. A.; Cowell R.; Peddie L.; Sharpe G. S.; 
Thatcher D. R.; Hanak J. A. J. Production of plasmid DNA for human gene therapy using modified alkaline cell lysis and expanded bed anion exchange chromatography. Bioseparation 1999 (8) 209-17

Vinci V. and Parekh S. R. Handbook of industrial cell culture: mammalian, microbial, and plant cells. Humana Press, 2003

Weir N. in Biotechnology (Eds: Mountain A.; Ney U. M.; Schomburg D.), 5a, Wiley-VCH, Weinheim, 1999

WHO Guidelines for assuring the quality of DNA vaccines, Biologicals, 1998, 26, 205.

Williams J. A.; Luke J.; Langtry S.; Anderson S.; Hodgson C. P.; Carnes A. E. Generic plasmid DNA production platform incorporating low metabolic burden seed-stock and fed-batch fermentation processes. Biotechnol. Bioeng. 2009a (103) 1129-43

Williams J. A.; Hodgson C. P.; Carnes A. F. Rapid process development for high yield plasmid DNA fed-batch fermentation. Biopharm International 2009b, 22 (11) 46-52

Wright, J. Generation of plasmid DNA for the application of transient transfection in mammalian cells. These 2486. Ecole Polytechnique Federale De Lausanne. 2001 


\section{CONCLUSION AND FUTURE WORK}

The goal of this thesis was to investigate both the technical and operational feasibility of scaling transient gene expression to large scale for the production of full-length, human-like glycosylated antibodies as medical countermeasures for biological catastrophe. Operational simulations predicted that a 1,000-L fermentor would produce sufficient plasmid DNA at a cost of approximately $\$ 377 /$ gram (Chapter 5 ). This DNA could be utilized in a $200,000-\mathrm{L}$ bioreactor facility produce between 32 and $1,274 \mathrm{~kg}$ of recombinant antibody within 3 months of operation. Simulation with experimentally validated parameters in the same facility resulted in production of $197 \mathrm{~kg}$ within 3 months at a cost of 705 \$/gram mAb (Chapter 4). These simulations predict that large-scale transient gene expression can provide sufficient lifesaving countermeasures if titer improvements are possible and can scale to 25,000-L bioreactors. Experimental transfections identified optimal cell/DNA/PEI ratio, transfection incubation time, temperature, and agitation set points which could be scaled to very large bioreactors. Through this process characterization, a method was developed using scalable cross flow filtration which achieved the highest reported titer in CHO TGE (Chapter 3). In addition a phenomenological mass transport model was developed to investigate potential mass transfer limitations upon scale-up. This model identified methods that could guide selection of scale-up regimes (Chapter 2).

Ultimately, this work has predicted the possibility of achieving large scale transfections. Future work could include pilot scale studies to validate the findings from this thesis and further develop capabilities for rapid production of very large quantities of recombinant protein. Other, less costly efforts could be directed at further developing process understanding of TGE. 
Specifically, understanding agitation's effect on polyplex formation and stability in cell culture media would provide needed insight into the mass-transport limitations of TGE. This could take the form of a correction factor for the mass-transport model which could provide additional predictive capability and determine if polyplex degradation plays a role in determining the mass transfer requirements. Moreover, investigating transfected cell's shear sensitivity may indicate additional factors to consider when developing TGE compatible bioreactors.

Other efforts could be directed at optimizing TGE in CHO with molecular biology methods. This could include strain engineering of anti-apoptosis cell lines and introducing episomal replication machinery. Such efforts may involve partnering with other research groups or firms who have already made advances in these areas. Moreover, developing nuclear-tags on polyplexes and enhance intra-cellular transport may ultimately provide the best gains in TGE performance.

Last, development of process simulation models for TGE in disposable bioreactors may be invaluable. While large scale fixed capacity is available, the use of such facilities will require complex contracts involving a host of stake-holders. Development of optimal single use technologies for TGE would provide an alternative, complimentary path to help mitigate the impact of a biological catastrophe. 